\title{
IntechOpen
}

\section{Career Development and Job Satisfaction}

\author{
Edited by Josiane Fahed-Sreih
}





\section{Career Development and Job Satisfaction Edited by Josiane Fahed-Sreih}



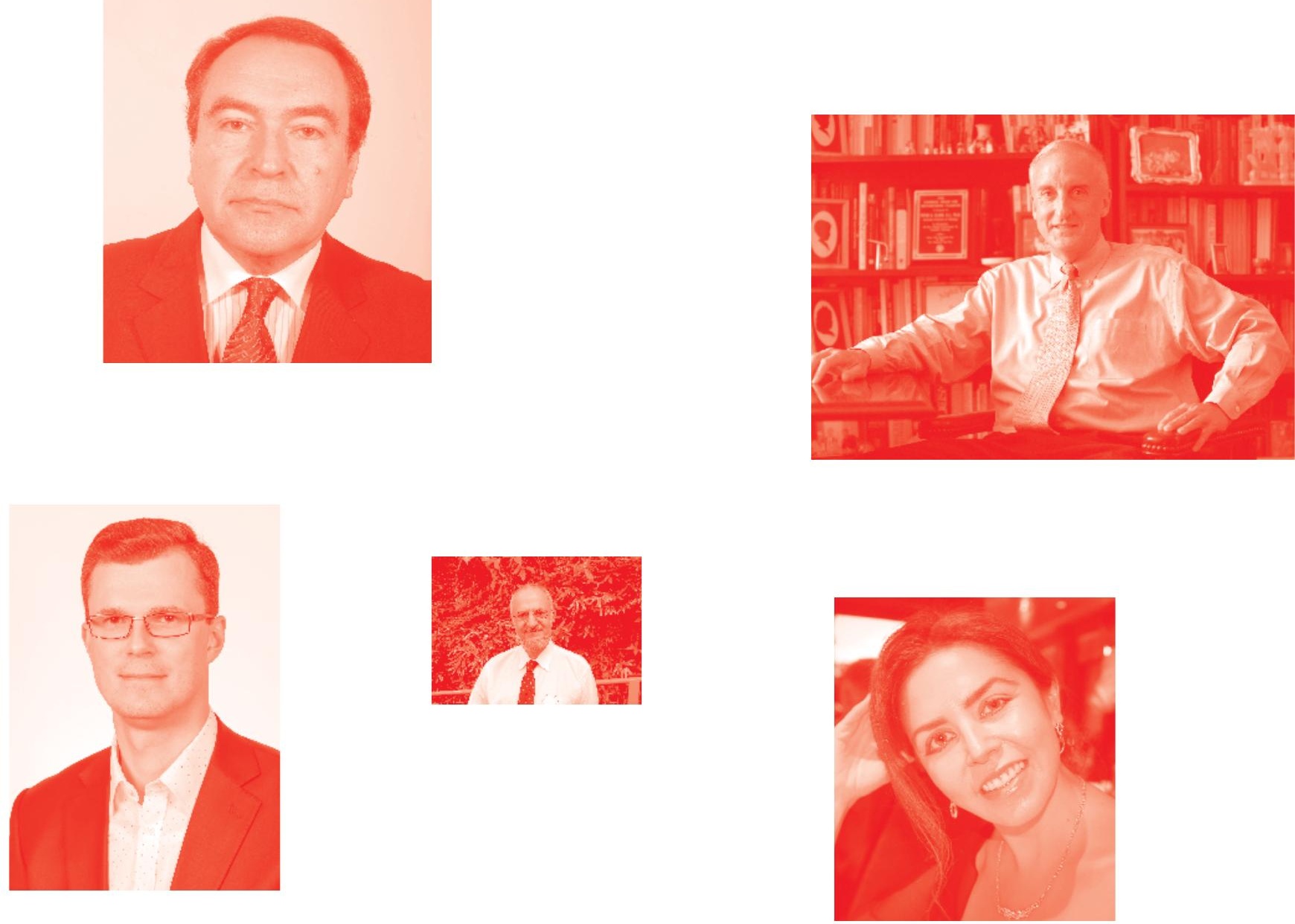

Supporting open minds since 2005
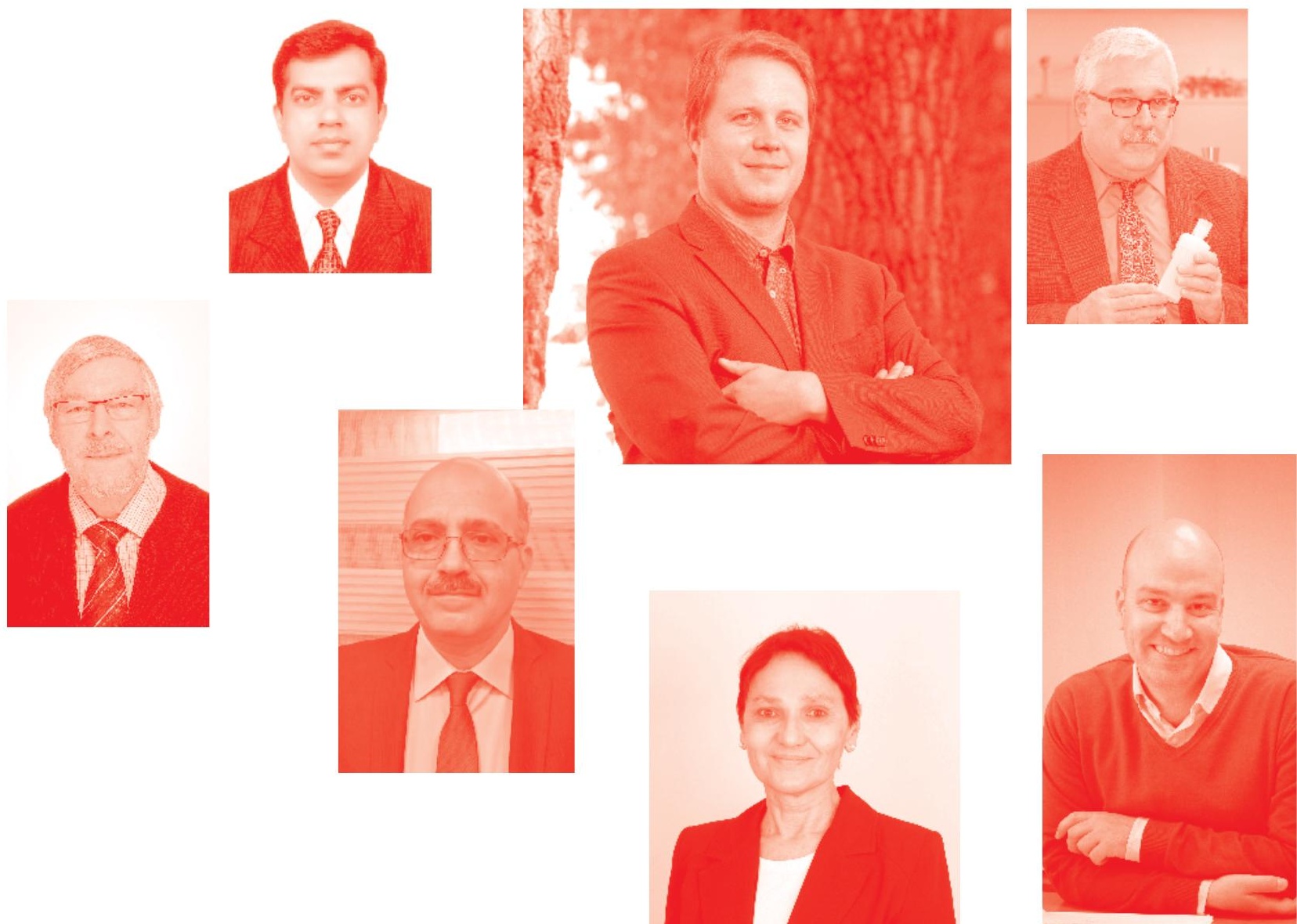
Career Development and Job Satisfaction

http : //dx. doi.org/10.5772/intechopen . 82999

Edited by Josiane Fahed-Sreih

\section{Contributors}

Wen-Rou Huang, Josiane Fahed-Sreih, Mitashree Tripathy, Ratna Sinha, John Burgess, Mirsad Bahtic, Verma Prikshat, Alan Ray Nankervis, Kenneth Kponou

๑) The Editor(s) and the Author(s) 2020

The rights of the editor(s) and the author(s) have been asserted in accordance with the Copyright. Designs and Patents Act 1988. All rights to the book as a whole are reserved by INTECHOPEN LIMITED . The book as a whole (compilation) cannot be reproduced, distributed or used for commercial or non-commercial purposes without INTECHOPEN LIMITED's written permission. Enquiries concerning the use of the book should be directed to INTECHOPEN LIMITED rights and permissions department (permissions@intechopen.com).

Violations are liable to prosecution under the governing Copyright Law .

\section{(cc) BY}

Individual chapters of this publication are distributed under the terms of the Creative Commons Attribution 3. 0 Unported License which permits commercial use, distribution and reproduction of the individual chapters, provided the original author(s) and source publication are appropriately acknowledged. If so indicated, certain images may not be included under the Creative Commons license. In such cases users will need to obtain permission from the license holder to reproduce the material. More details and guidelines concerning content reuse and adaptation can be found at http : //www . intechopen. com/copyright-policy. html.

Notice

Statements and opinions expressed in the chapters are these of the individual contributors and not necessarily those of the editors or publisher. No responsibility is accepted for the accuracy of information contained in the published chapters. The publisher assumes no responsibility for any damage or injury to persons or property arising out of the use of any materials, instructions, methods or ideas contained in the book.

First published in London, United Kingdom, 2020 by IntechOpen

IntechOpen is the global imprint of INTECHOPEN LIMITED, registered in England and Wales, registration number: 11086078 , 5 Princes Gate Court, London, SW7 2QJ, United Kingdom Printed in Croatia

British Library Cataloguing-in-Publication Data

A catalogue record for this book is available from the British Library

Additional hard and PDF copies can be obtained from orders@intechopen.com

Career Development and Job Satisfaction

Edited by Josiane Fahed-Sreih

p. cm.

Print ISBN 978-1-83880-746-7

Online ISBN 978-1-83880-747-4

eBook (PDF) ISBN 978-1-83880-748-1 


\section{We are IntechOpen, \\ the world's leading publisher of Open Access books}

Built by scientists, for scientists

\section{$5,000+$ \\ $125,000+$ \\ International authors and editors \\ $140 \mathrm{M}+$ \\ Downloads}

Our authors are among the

151

Countries delivered to

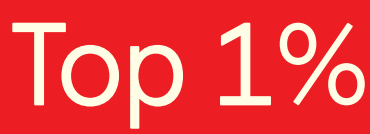

most cited scientists

Contributors from top 500 universities

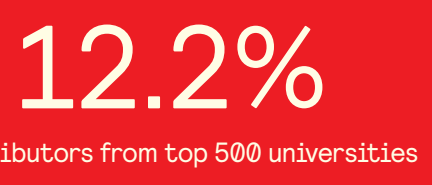

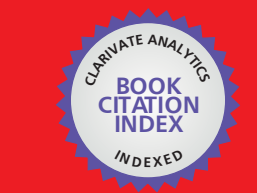

WEB OF SCIENCE ${ }^{\text {M }}$

Selection of our books indexed in the Book Citation Index

in Web of Science ${ }^{\mathrm{TM}}$ Core Collection (BKCI)

\section{Interested in publishing with us? \\ Contact book.department@intechopen.com}

Numbers displayed above are based on latest data collected.

For more information visit www.intechopen.com 



\section{Meet the editor}

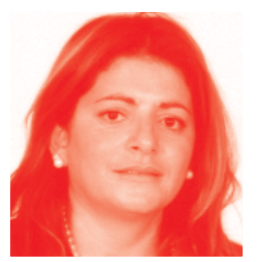

Dr. Josiane Fahed-Sreih is a full time Associate Professor of Management in the School of Business at the Lebanese American University. She is the founder and currently the Director of the Institute of Family and Entrepreneurial Business at the Lebanese American University. She is the chairperson of the Department of Management. She held the position of Assistant Dean at the School. She holds a Ph.D from the Sorbonne University and is a fellow member of the Family Firm Institute, USA. She holds the responsibility of the Middle East Coordinator for the Family Firm Institute, USA. She is a Family Wealth and Family Business Consultant. She is the winner of the 2007 International Award from the Family Firm Institute in the USA, in recognition for outstanding achievement in furthering the understanding of family business issues that occur between two or more countries. She has participated and organized international conferences, workshops and seminars. She has presented at major conferences locally and internationally and has been consulted on management issues in many countries and especially the Middle East: Saudi Arabia, UAE, Jordan, Qatar, Kuwait, Syria, Bahrain, Oman, France, Cyprus and Lebanon. She currently sits on five boards of directors as a shareholder: two as a Chairman of the board, and one as an independent director in the private sector. She is also involved as an advisor on boards of community service organizations.

She speaks regularly to trade and professional groups, and presents her research in academic conferences worldwide. She is frequently invited as a key note speaker to recognized Family Business and Corporate Governance conferences. Her research interests are in management, family business management, boards of directors functioning and corporate governance. She published in 2004 her book in the USA on "Facts and Figures Concerning Family Businesses in Lebanon", in 2017 her book on "Conflict in Family Businesses: Conflict Models and Practices" with Palgrave Macmillan and another book on the "How to Manage Family Businesses: The 10 imperatives for success" with Cambridge Scholars. Moreover, she has contributed to many compendiums on family business management in the Middle East in articles, chapters in books, book reviews, and academic articles in rated internationally refereed journals. She is on the Editorial Board of the Family Business Management Journal and also acts as a reviewer for academic family business, corporate governance, and management journals. 



\section{Contents}

Preface

Chapter 1

Introductory Chapter: Job Satisfaction and Career Development

by Josiane Fahed-Sreih

Chapter 2

Career Development: An Enabler for Job Satisfaction

by Ratna Sinha

Chapter 3

Significance of Soft Skills in Career Development

by Mitashree Tripathy

Chapter 4

Job Training Satisfaction, Job Satisfaction, and Job Performance

by Wen-Rou Huang

Chapter 5

Maintaining Positive Employee Relations: Does It Apply to Millennials? by Josiane Fahed-Sreih

Chapter 6

Contract, Gender, and Job Satisfaction: Evidence from Benin

by Monsoï Kenneth Colombiano Kponou

Chapter 7

Go Back to the Beginning: Career Development and the Challenges of Transitioning from the Military to Civilian Employment by Mirsad Bahtic, Verma Prikshat, John Burgess and Alan Nankervis 



\section{Preface}

Human resource management is the process of acquiring, training, appraising, and compensating employees while attending to their labor relations, their health, safety, and equity concerns. Minding fairness in the process is part of successful human resource management.

This book, "Career Development and Job Satisfaction”, not only looks at how employees can develop their careers and create career paths that are meaningful for their lives, it also looks at keeping employees satisfied with their jobs.

This book also focuses on careers and career development in the management of human resources. It also gives a practical perspective on how managers apply non-human resource personal competencies such as ethical decision making and business knowledge when carrying out personnel tasks such as developing careers and making sure employees are satisfied.

Reading this book will provide you with skills to use in your management career. It will highlight working with the millennial generation and how to motivate them and guide them through their careers. It presents case studies on satisfaction and career planning.

I am indebted to many people for their assistance in making this project happen.

I appreciate the hard work and suggestions from the reviewers, in addition I am grateful to my research assistant Ms. Lynn Chahine for doing the work I can hardly find time to finish and the Author Service Manager Mr. Mateo Pulko. I am also grateful to all the authors who contributed their work and knowledge to make this book exceptional; namely Wen-Rou Huang, Mitashree Tripathy, Ratna Sinha, John Burgess, Alan Nankervis, Verma Prikshat, Mirsad Bahtic and Kenneth Kponou. The cooperation of all made the project a success.

Josiane Fahed-Sreih 



\title{
Introductory Chapter: Job Satisfaction and Career Development
}

\author{
Josiane Fahed-Sreih
}

\section{Job satisfaction and employee engagement}

Job satisfaction is considered as the amount or degree of gratification and contentment that an employee fosters towards his/her overall job, factoring into that equation his/her satisfaction with the job itself, the peers at the job, the supervisors, and the policies at work [1]. Various research studies have highlighted the importance of focusing on the issue of employee job satisfaction, as it plays a critical role in overall firm success or demise. Additionally, the importance of employee job satisfaction has been largely emphasized in the literature because of its positive affect on employee job performance. The productivity of the work force, in any organization, is a major driver which leads to achieving organizational goals. This stresses on the importance of further focusing on job satisfaction as an essential concern for family firms and large corporations equally [2].

Recently, organizations have focused on maximizing productivity in order to maintain their competitive stance and better deal with emerging trends such as globalization. Nowadays, the general direction which firms take when expanding is into international markets that reveal potentially rewarding new opportunities. However, whether it is answering to customer needs or developing and growing on its own, a company needs to ensure that its workforce is as productive as possible, and in order for the workforce to perform at its utmost productivity, employees must feel a satisfaction relating to the nature of the work they are performing.

In order to achieve this ultimate productivity, it is suggested that organizations should define major issues that might actually affect the level of employee job satisfaction and attempt to tackle these occurrences which hinder an employee's level of satisfaction at work. For instance, Inuwa [2] discusses in his writings how job satisfaction is related to performance. The results of his analyses showed how an employee's motivation towards being productive at work will increase the more the employee is satisfied with the job, leading to the achievement of the overall organizational goals. If not, the employee will be demotivated, and in turn, this will impact the overall achievement of the predetermined organizational goals.

Furthermore, whenever the factors in the organizations that affect employee's motivation are managed, better employee outcomes and performance are created. Therefore, the more the employee motivation, the better the outcome of employee performance. This sheds light on the highlighted relationship between job satisfaction and employee engagement. Results of multiple studies show that the more engaged the employees are, the higher their job satisfaction is. This is due to the fact that employees who feel engaged at work will have better, more efficient, and more productive working behaviors, attitudes, and motivations $[3,4]$. On the other hand, 
job dissatisfaction can have serious consequences on the productivity of the firm, one of which is employee turnover. Turnover is when the employee decides to leave the organization [5].

Job satisfaction is important for employees to stay in the organization. Understanding generational differences among different generations and their perception of job satisfaction is of huge and utmost importance [6]. Organizations must know what actually satisfies a person to stay in the organization, since a satisfied employee will work for the interest of the organization, which in turn leads to better overall work performance. Moreover, based on the findings of a research study conducted by Acharrya [7], there are four aspects which contribute to the satisfaction of millennials: training, commitment of the organization to developing employees, career development, and career opportunities.

\section{Job satisfaction and career development}

Companies must also consider career development as a new key to retain their employees especially that in the next 10 years, millennials would be representing the bulk of the workforce. Career development is the ongoing process of learning, developing, and moving towards one's goals. Moreover, career development has its own advantages, one of which is the fact that it reduces turnover and increases employee motivation. Career development is in the interest of all generations, yet it is mostly sought after by the millennials, and thus, it plays a major factor in their job satisfaction. Career development includes extensive training, in specific, with respect to the areas the employee wants to develop. Having mentioned job satisfaction and career development and the importance of the effect of one on the other, it is time to discuss the relationship between these two variables.

Career development contains structured, dignified, and deliberate exertion of effort, in order to accomplish a state of evenness between the organization's objectives and strategies and the employee's career goals as well as the progress that he/ she seeks [8]. The proper career preparation and career supervision will lead to the best results of career development. McDaniels and Gysbers [9] mention that career development is the collection of mental, sociological, informative, corporal, financial, and unplanned factors that are shared to form the career of any targeted employee.

Career development depends on the organization's decision to transfer employees from their traditional work, and the tasks that are common to them, to more challenging work that is enriched with initiatives for self-development and organizational effectiveness. An effective career development plan helps the organization to benefit from its internal talent by corresponding the experience and skills gained by the employees and linking them to the organization's needs, while also motivating and engaging the employees to give more effort by the compensation and succession plans given for the sake career development [10].

Lee [11] mentions that companies who participates in career management are going to enhance their employees' job satisfaction. Gregson [12] mentions that job satisfaction is the state of emotion that the employee feels fulfillment in after his performance management review and experience in the organization. Chay and Bruvold [13] state that job satisfaction is the positive reaction of the employee to different phases of the job. Job satisfaction happens after the employee experiences emotions of self-actualization in his/her career [14].

Career development programs were found to have a positive inspiration on job satisfaction, professional development, and productivity in a research conducted by Chen, Chang, and Yeh [15]. Moreover, in a research study conducted by 
Schein [16], it was found that career development plays a major role in employee effectiveness and creativity over the long term. Moreover, a well-organized career development will allow employees to pursue improvements in their career that will actually lead to the employees' job satisfaction [16]. Moreover, Schein [16] adds that employees will have different career developments according to their preferences, goals, and, most importantly, the external factors such as global business changes. Schein [17] elaborates more to state that employees have different work needs at each stage of their career path and organizations should take into consideration the career needs of their employees in each stage to satisfy their career development and increase the organizational effectiveness and cope with its needs as well. Each specific stage of career development has different goals and different mission from the next one [18].

Furthermore, organizations should be responsive and open to career developments of their employees because modernization and improvement is the field where each company differentiates itself from its competitors and, at the end, it is the responsibility of the employee to gain the knowledge through his/her experience when everything is provided to him/her by the organization [19]. Although the managers with the guidance of the human resources departments set the career development plan for the employee, each employee enters the company with a career development plan in his/her mind that he/she wishes to obtain through his/her experiences within the organization. In fact, many career plans suggested by the employees are considered by the managers and are accepted to be beneficial for them [20].

Additionally, any company that implements career development plans for its employees will, in fact, reduce its employees' turnover rate [20]. Hoon [19] mentions that career planning, management, and development that are respective with human resources guidance influence employees' job satisfaction. Robbin [21] mentions that if there exist a gap in the career needs of the employee there will be stress and anger between coworkers, which in fact impacts the job satisfaction level in employees. Chen, Chang, and Yeh [15] study in their research the relationship between job satisfaction and the gap that exists between career development programs and career needs. In the case of Taiwan, where organizations are working to increase their competitiveness and become more involved in high tech production and development, the gaps existed between career development programs and expected career needs of production, and development has improved the job satisfaction in R\&D employees [15]. However, widening the gaps between career development plans and employee career needs will lower job satisfaction in R\&D employees [15]. Moreover, the gap changes in each career stage influences the job satisfaction differently [15]. In addition, as the gap widens, employees that are on the establishment stage of their career will get lower job satisfaction, and those that are on the maintenance stage will get higher job satisfaction than those on any other career stage [15].

Several changes in the company such as downsizing, rightsizing, and flattening affect the career development of employees in the company for the future. Moreover, employees are more satisfied with their jobs and give it their best when they sense well-organized developmental career plans that support their development and advancement to reach high levels and learn more through this career path [22]. In addition, career development for employees aids in the competitiveness of the company in the market by addressing the organizational needs of employees when developing them [22]. Companies that implement a person-environment theory tend to have the best career development of their employees and foresee employees' needs as much more important in order to know how to improve the interaction of the employee with his work environment $[23,24]$. 
Potgieter, Coetzee, and Ferreira [25] mention in that the person-environment fit is essential for the sake of a workers' job embeddedness and career. Moreover, the person-environment fit is determined by the employee satisfaction with his position in the company, culture, and work environment. Also, it is determined by the career development and employee expectations [22, 23]. The authors Potgieter, Coetzee, and Ferreira [25] mention that the result of their research that is facilitated by the person-environment fit theory is the embeddedness of employees in their career development, which will help the employee to acquire job satisfaction of his position and career. Thus, accomplishing employees' career needs to develop will play a huge role in the job satisfaction of the employee [25].

Furthermore, hopes for improvements in jobs were increased by $20 \%$ when the term career development was initiated [26]. There are specific career counselors in many organizations that are known for career development; now career counselors are included in the tasks of the human resources development department [27]. The importance of the link between career development and job satisfaction was attracting the researchers [26]; a link between the two conducts was first detected by Gregson [12]. The results of the research conducted by Pearson and Ananthram [28] are that those organizations that fail to accomplish employee satisfaction will experience a nonstop of employee crisis. Moreover, employees retained in organizations that gave them the opportunity to be engaged in their career development plan. Most importantly is that young employees doing their job and attaining career development make their job more than just a job [28]. Career development boosts the young employees' efforts in the organization and makes them stick to the company. The authors highlighted on the importance of the link between job satisfaction and career development in increasing job retention and boosting effort of employees [28]. Career development will result in job satisfaction and especially in younger employees [28].

\section{Author details}

Josiane Fahed-Sreih

Department of Management, Institute of Family and Entrepreneurial Business, Lebanese American University, Lebanon

*Address all correspondence to: jsreih@lau.edu.lb

IntechOpen

(C) 2020 The Author(s). Licensee IntechOpen. This chapter is distributed under the terms of the Creative Commons Attribution License (http://creativecommons.org/licenses/ by/3.0), which permits unrestricted use, distribution, and reproduction in any medium, provided the original work is properly cited. (cc) BY 


\section{References}

[1] Locke EA. What is job satisfaction? Organizational Behavior and Human Performance. 1969;4(4):309-336

[2] Inuwa M. Job satisfaction and employee performance: An empirical approach. The Millennium University Journal. 2016;1(1):90-103

[3] Radosevich DJ, Radosevich DM, Riddle MR, Hughes PA. Goal orientation as a predictor of cognitive engagement, performance, and satisfaction. Journal of Academy of Business and Economics. 2008;8(3):46-55

[4] Wefald AJ, Downey RG. Construct dimensionality of engagement and its relation with satisfaction. The Journal of Psychology. 2009;143(1):91-112

[5] Lu L, Lu ACC, Gursoy D, Neale NR. Work engagement, job satisfaction, and turnover intentions. International Journal of Contemporary Hospitality Management. 2016;28(4):737-761

[6] Kaifi BA, Nafei WA, Khanfar NM, Kaifi MM. A multi-generational workforce: Managing and understanding millennials. International Journal of Business and Management. 2012;7(24):88

[7] Acharyya R. Job Satisfaction for Millennials: Statistics and Analysis. 2018. Available from: http://www. careerizma.com/blog/job-satisfactionmillennials-statistics-analysis/

[Retrieved: 20 May 2020]

[8] Leibowitz ZB, Farren C, Kaye BL. Designing Career Development Systems. 1st ed. San Francisco: Jossey-Bass Publishers; 1986

[9] McDaniels C, Gysbers NC. Counselling for Career Development. 1st ed. San Francisco: Jossey-Bass Publishers; 1992

[10] Martin AF, Romero FP, Valle CR, Dolan SL. Corporate business strategy, career management and recruitment: Do Spanish firms adhere to contingency model? Career Development International. 2001;6(3):149-155

[11] Lee SH. A managerial perspective of the objectives of HRM practices in Nigeria: An exploratory study. Nigeria Management Review. 2000;22(1):65-82

[12] Gregson T. Factor analysis of multiple-choice format for job satisfaction. Psychological Reports. 1987;61(5):747-750

[13] Chay HL, Bruvold NT. Creating value for employees: Investment in employee development. International Journal of Human Resource Management. 2003;14(6):981-1000

[14] Noe RA. Human Resource Management_Gaining a Competitive Advantage. 2nd ed. New York: Irwin McGraw-Hill; 1996

[15] Chen TY, Chang PL, Yeh CW. The study of career needs, career development programmes and job satisfaction levels of R\&D personnel: The case of Taiwan. The International Journal of Human Resource Management. 2004;14(6):1001-1026

[16] Schein EH. Career Dynamics: Matching Individual and Organizational Needs. Reading, MA: Addison-Wesley; 1978

[17] Schein EH. Organizational Psychology. 3rd ed. Englewood Cliffs, NJ: Prentice-Hall; 1980

[18] Schein EH. Individuals and carrers. In: Lorsch JW, editor. Handbook of Organizational Behavior. Englewood Cliffs, NJ: Prentice-Hall; 1987. pp. 155-171

[19] Hoon LS. A managerial perspective of the objectives of HRM practices 
in Singapore: An exploratory study. Singapore Management Review. 2000;22(1):65-82

[20] Chang E. Career commitment as a complex moderator of organizational commitment and turnover intention. Human Relations. 1999;52(10):1257-1278

[21] Robbin SP. Organizational Behavior: Concepts, Controversies, and Applications. Englewood Cliffs, NJ: Prentice Hall; 1998

[22] Capuzzi D, Stauffer MD. Career Counseling: Foundations, Perspectives and Applications. New York, NY:

Pearson; 2006

[23] Dawis RV, Lofquist LH. From TWA to PEC. Journal of Vocational Behavior. 1993;43:113-121

[24] Dawis RV. The theory of work adjustment and person-environment correspondence counseling. In: Brown D et al., editors. Career Choice and Development: Applying Contemporary Theories to Practice. 3rd ed. San Francisco, CA: Jossey-Bass; 1996. pp. $75-120$

[25] Potgieter IL, Coetzee M, Ferreira N. The role of career concerns and workplace friendship in the job embeddedness-retention practices satisfaction link. SA Journal of Industrial Psychology. 2018;44(1):1-9

[26] Burke R. Do managerial men benefit from organizational values supporting work-personal life balance? Women in Management Review; 2000

[27] Dodson TA, Borders LD. Men in traditional and non-traditional careers: Gender role attitudes, gender role conflict, and job satisfaction. The Career Development Quarterly. 2006;54(4):283-296
[28] Pearson C, Ananthram S. Career development, job satisfaction, and career commitment: Evidence from the Singaporean hospitality industry. Paradigm. 2008;12(2):12-28 


\title{
Career Development: An Enabler for Job Satisfaction
}

\author{
Ratna Sinha
}

\begin{abstract}
Successful organizations exist because of a competitive edge in the global economy. In order to maintain the status, firms need talented and engaged employees. The endeavour for human resources function is to have practices which have an impact and make a positive difference in the lives of employees. An important practice is career development. Career development programmes enable HR managers, managers and their stakeholders to work together to plan, organize, formalize, lead and monitor career programmes to develop not only employees' jobs but the whole stage process, attitude, behaviour and state of affairs relating to employees' work life. Employee satisfaction can be achieved by making a good career development system and giving an understanding of how important the system is that is designed by the company for managerial and professional employees.
\end{abstract}

Keywords: career development, job satisfaction, career development programmes, employee satisfaction, human resource

\section{Introduction}

Successful organizations exist because of a competitive edge in the global economy. In order to maintain the status, firms need talented and engaged employees [1-3]. Several recent research studies have focussed on the importance of retaining valuable human capital in today's competitive world of work [4-7]. The endeavour of human resources is to have impactful human resources practices which make a positive difference in the lives of employees. An important practice is career development. The extant literature suggests that there is a widespread acceptance of the value of career development activities and that, in the years to come, more and more organizations will be required by various internal and external pressures to develop and expand career development services [8].

\section{Importance and relevance of career development}

Career development is a significant path of knowledge management, effort, freedom and evolution to move towards a personally resolute and developing preferred future. Leibowitz and Lea [9] described career development systems as integrated services and procedures that meet the needs of both individuals and organizations. 
Chang et al. [10] posit that career development programmes enable HR managers, managers, and their stakeholders to work together to plan, organize, formalize, lead and monitor career programmes to develop not only employees' jobs but the whole stage process, attitude, behaviour and state of affairs relating to employees' work life.

Job satisfaction is influenced by people, supervisors and co-workers in the workplace, compensation and the work environment [11]. Locke [12] defined job satisfaction as the pleasurable or positive emotional state resulting from the overall evaluation of one's job or job experiences.

Employee satisfaction can be achieved by making a good career development system and giving an understanding of how important the system is that is designed by the company for managerial and professional employees [3, 13].

We all know that businesses exist to attain high productivity in their working styles and produce a competitive edge in the global economy. To achieve this edge and high efficiency, firms need talented and engaged employees. The role of human resources management becomes even more important than ever in this competitive era. An approach, which is a panacea to this managerial need, is the implementation of career development process [14].

Career development is one such significant practice which enhances the level of employee engagement, which in turn subsequently increases the organizational effectiveness. The purpose of career development is to match the employees' aspirations with the firm's challenges that could result in organizational effectiveness. Organizations that want to attract, motivate and retain employees need to show concern towards employee career development. Abdelnour and Hall [15] stated that organizations can no longer afford to squander valuable human resource assets because employee development leads to corporate development. That the talent generates a lot of company performance and is a source of a competitive advantage, it is important to create conditions for intra-organization movements (internal job posting) and to offer many career management practices such as succession planning, coaching, mentoring, rotation, development plans, individual information on opportunities for career development and others [16].

In order to understand the implementation of career development programmes, it is essential to run a survey on the kind of audit to be carried out. This will help in estimating the career development needs of the organization (Figure 1). Organization's need cannot be satisfied without satisfying individual needs [17]. Understanding the organizational culture and context with defined roles of those implementing needs to be well defined and articulated.

Each individual is different. He/she has different personalities, abilities, needs and desires. Therefore, career planning programmes should be based on the segmentation of employees, grouping them more by their needs, rather than hierarchical levels. Managers should create several different career development programmes customized for each segmented group and provide development programmes based on the assessment of the potential and performance of the employees, keeping in mind the needs and mission of the organization.

Having the right resources and support systems would enable in making the process effective based on the outcome of the need and the strategy built. There are a number of initiatives and practices which could give the perspective on the resources and supports.

One of the ways which can help is counselling. Counseling sessions are of great help to develop themselves because it provides a path towards achieving career goals. If an employee is in a state of not being able to choose from the options, counseling perhaps would show a positive path. Herr and Cramer [18] suggested that counsellors may be involved in team building; consultation with managers; 


\section{Implementation of Career Development Program}

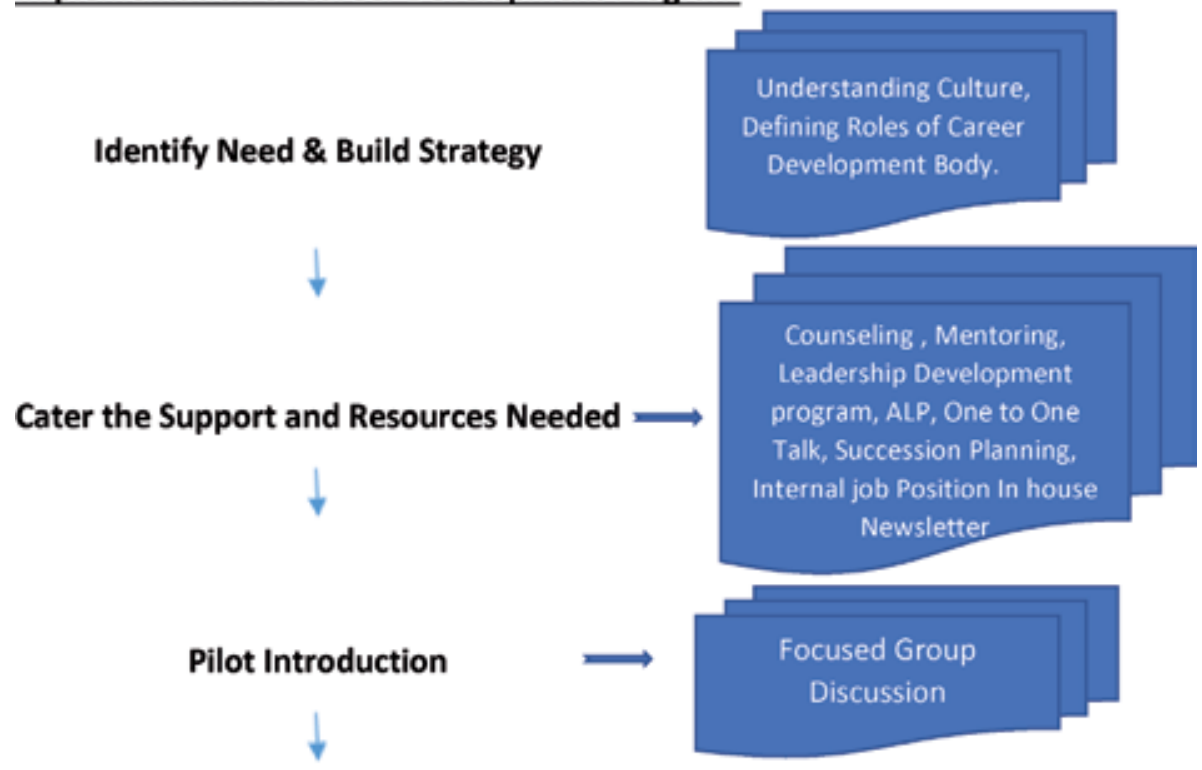

Implement on large scale

Figure 1.

Flow and implementation process of career development programme.

psychological crisis consultations; training in negotiating skills; assessing needs; training trainers; evaluating outside programmes; designing, presenting and evaluating training programmes; and interviewer training.

One-to-one talk brings in a conversation which is even more transparent and can come up sharing more openly especially those who keep to themselves and slowly lose interest and move out of the organization in time to come if they are not tapped at the right time and a chord is struck in a positive way.

In similar lines, mentoring programmes give that support which an employee looks towards to discuss and share with his mentor who is a friend, philosopher and guide. Corporate mentoring programmes reveal much benefit in days to come for the employee. Mentors provide a perspective of leadership. External mentors and so does a coach provide a constructive feedback.

According to Savickas and Baker [19], career psychology is in need of reinvigoration to respond to the challenges of rapid transformation in a postmodern world.

Leibowitz and Lea [9] and Brown and Brooks [20] suggested that more research in the area of career development may result in more organizational support.

Comparatively the number of career development services available, there is very little research published on their effectiveness [21].

Secondly, company's leadership programmes chalk out career development plans for an employee. There could be action learning projects chalked out as a career development plan which accelerates his growth and development and the same time plugs his gaps by working as a member of the project team. Self-directed workbook aimed at guiding career planning and analysis of the individual gives a record and shows a document of progress keeping an individual spirited on his journey of career development. The primary aim of the career planning programme is not to help employees lay out a career plan per se but to help employees in being focussed to acquire skills essential for planning their own career. 
Group workshop is another way which could help employees evaluate their skills, abilities and interests and to formulate development plans.

If the organizations arrange training sessions by investing in their employees' career, then the organizations in return acquire the most talented and satisfied workforce [22]. It is a continuous process that gives an employee the set of new skills and sharpens the existing ones.

In addition, succession plans and job rotations vertical or horizontal enable an employee to see these as opportunities. It is seen as one of the career development activities which is useful in enhancing their knowledge, skills and abilities to improve job performance and adding value to current and future jobs bringing in a sense of fulfillment and value. Career development should be implemented effectively because it can affect the sustainability of the company [23].

There are even apps today which work on career development. One would say it a 'cool tool'. 'Whatfix' is an electronic performance support platform that can provide in-app guidance within business applications. Using this platform, talent development professionals can train and support employees at their point of need. However, the contact on a person-to-person keeps an exchange of mind and gives a support to the emotional self.

Yet another platform which enables an employee visibility especially more so in large organizations is featuring an employee in company's in-house newsletter. This kind of platform creates an image and gives connection in organizations on the availability of a profile which could fit in other engaging roles.

The social exchange theory primarily dwells upon feelings of personal obligation, gratitude, and trust [24]. Social exchange theory [24] can be used to predict the outcomes of different management practices.

Career development programmes provide stimulation and fulfillment at numerous phases of employee development, proactively finding capacity in advance and granting prospects for learning. Tziner [25] defines job satisfaction as the extent to which individual needs are met in the work setting.

Employee satisfaction can be achieved by making a good career development system and giving an understanding of how important the system is that is designed by the company for managerial and professional employees $[3,13]$. Investing in professional development of employees allows differentiation and gaining competitive advantage, as it also increases the level of abilities and knowledge the organization can use to achieve organizational goals [26].

However, good career development can be manifested when it is actualized in day-to-day behaviour by all in the organization [27]. Meta-analytic support also exists for the positive relationship between individual career management behaviors and career satisfactions [28].

Today, employees are more conscious about their professional and personal growth. Organizations that do not align themselves to this thought process eventually lose their talented workforce.

Traditionally career was considered to be confined to professionals or those who advanced through organizational hierarchy; in terms of today 'career', it is more appropriately meant to be the lifelong sequence of the role-related experiences of individuals [29].

Employees of today know that they could be out of date if they do not enhance their knowledge and skill. They too would look out for opportunities to upgrade; therefore companies providing that support of career development programmes make a huge difference in their engagement and satisfaction in their career life. The flip side is that too much of raising expectations and there being not enough roles could lead to dissatisfaction, and one would then go beyond the frontiers of their own organization. Being straightforward about career options builds trust and rests no false notions. 
Super [30] referred to the specific stages of 'exploration', 'establishment', 'maintenance' and 'disengagement', noting that individuals have different career development tasks and characteristics at different stages of their careers [31].

$\mathrm{Yu}$ [32] affirms that studies on workplace career programmes highlight the fact that the ability of the management to properly plan and manage career programmes for employees who work in different job categories may have a significant impact on employee outcomes, especially job satisfaction.

It is essential that the practices as per the strategy need to be piloted before we move forth into a full implementation.

One looks at career as a life's fulfilling journey. The employee is more concerned about his/her career and personal development and transformation throughout his work life.

Ismail et al. [33] correlate on career development and job satisfaction, as the readiness of management to appropriately plan and manage career programmes adequately which assists employees to develop career paths and, as a result, may lead to higher job satisfaction in the organization. Employees need the encouragement, resources, tools and support to envision their futures. It is not necessary that organizations need to provide new app or programme, but they do need conversations with managers, coaches or mentors. Even if the salaries are not high, corporates with career development programme and experience of job satisfaction exist [34].

\section{Limitations}

This study concludes with suggestions for future research. First of all, this study is a more qualitative study of career needs. Future studies could include data through surveys or through longitudinal studies which could result in promising outcomes. In addition it is also foreseen that the development of valid and reliable measures of career needs is one of the primary challenges for those researchers interested in taking this aspect forwards.

\section{Practical implications and conclusion}

Grappling with situations and circumstances in the journey of the future of work, change is inevitable and can influence numerous events inside and outside an organization. Seen through the theoretical lens and on ground practices, the findings added new insights into the circumstances under which employee can work in the process flow articulated implemented by the organization which would influence positively employee satisfaction with organizational retention practices.

The contrasting attitudes of acceptance and resistance to change are an increasingly interesting topic in today's global, ever-changing and competitive environment. Career development truly forms an enabler to job satisfaction. If one hops in the bandwagon, the feeling could be comforting in the beginning. One needs to filter the popular demand and peer pressure, rather than to think objectively and assess his own competency, skill and passion, and then take a call.

The implication is that individuals will then find their jobs to be more meaningful and enjoyable. It plays a pivotal role in the ecosystem of the entire gamut of development-related processes. Managers should ensure that they frequently review employees' career concerns through formal career discussion and have conversations. It requires alignment of human resource systems like performance management, career development and succession planning. In addition, it involves 
establishing an integrated career development system to support current and future business needs with continuous development and upgrade of people.

Career development programmes should be flexible in order to adapt to the changing economic scenario.

The readiness of individuals within organizations and their ability to make an edge are the factors which influence the opportunities in career development. Having career conversations and advancements will enable an employee to be satisfied, will keep them engaged and give them a sense of fulfillment in the journey of employment and work life. It is trusted that this research will inspire further research on the topic, which will align organizational and employee needs.

\section{Author details}

Ratna Sinha

XLRI, Kolkata, India

*Address all correspondence to: ratna_sinha@hotmail.com

\section{IntechOpen}

(C) 2020 The Author(s). Licensee IntechOpen. This chapter is distributed under the terms of the Creative Commons Attribution License (http://creativecommons.org/licenses/ by/3.0), which permits unrestricted use, distribution, and reproduction in any medium, provided the original work is properly cited. (cc) BY 


\section{References}

[1] Chang P-L, Chou Y-C, Cheng F-C. Career needs, career development programmes, organizational commitment and turnover intention of nurses in Taiwan. Journal of Nursing Management. 2007;15:801-810

[2] Puah A, Ananthram S. Exploring the antecedents and outcomes of career development initiatives: Empirical evidence from Singaporean employees. Research and Practice in Human Resource Management. 2006;14(1):112-142

[3] McCracken D. Winning the talent war for women: Sometimes it takes a revolution. Harvard Business Review. 2000;78:159-160, 162, 164

[4] Deas AJ. Constructing a psychological retention profile for diverse generational groups in the higher educational environment [ $\mathrm{PhD}$ thesis]. Pretoria, South Africa: University of South Africa; 2017. (Unpublished)

[5] Khaleel M, Chelliah S, Khalid J, Jamil M, Manzoor F. Employee engagement as an outcome of friendship at workplace: Moderating role of job embeddedness. International Journal of Academic Research in Business and Social Sciences. 2016;6(6):1-6

[6] Stoltz E. Employability attributes and career adaptability as predictors of staff satisfaction with retention factors [Master's dissertation]. Pretoria: University of South Africa; 2015. (Unpublished)

[7] Van Dyk J. The relationship between organisational commitment, retention factors and perceived job embeddedness [Master's dissertation]. Pretoria, South Africa: University of South Africa; 2012. (Unpublished)

[8] GutteridgeTG, Otte F. Organizational career development: What's going on out there? Training and Development Journal. 1983;37:22-26

[9] Leibowitz ZB, Lea DH. Adult Career Development: Concepts, Issues, and Practices. Silver Spring, MD: National Career Development Association; 1986

[10] Chen T-Y, Chang P-L, Yeh C-W. The effects of career development programs on R\&D personnel in Taiwan. Asia Pacific Journal of Human Resources [Internet]. SAGE Publications. 1 December 2006;44(3):318-341. DOI: $10.1177 / 1038411106069415$

[11] George JM, Jones GR. Understanding and Managing Organizational Behaviour. 5th ed. New Jersey: Pearson/Prentice Hall; 2008

[12] Locke EA. The nature and consequences of job satisfaction. In: Dunnette MD, editor. Handbook of Industrial Organizational Psychology. Chicago: Rand McNally; 1976. pp. 1297-1349

[13] Rutherford S. Different yet equal. In: Burke RJ, Mattis MC, editors. Supporting Women's Career Advancement. Cheltenham: Edward Elgar; 2005

[14] Adeniji AA, Salau O, Awe K, Oludayo O. Survey data on organisational climate and job satisfaction among academic staff in some selected private universities in Southwest Nigeria. Data in Brief (Elsevier). Science Direct. 2018;19:1688-1693

[15] Abdelnour BT, Hall DT. Career development of established employees. Career Development Bulletin. 1980;2:5-8

[16] De Vos A, Dries N. Applying a talent management lens to career management: The role of human capital composition and continuity. 
International Journal of Human

Resource Management. 2013;24(9).

DOI: 10.1080/09585192.2013.777537

[17] Lingham L. Career development and organizational training.

Career Development International. 2000;12(6):545-564

[18] Herr EL, Cramer SH. Career Guidance and Counseling through the Lifespan. 4th ed. New York: HarperCollins; 1992

[19] Savickas ML, Baker DB. The history of vocational psychology: Antecedents, origin, and early development. In: Walsh WB, Savickas ML, editors. Handbook of Vocational Psychology. Zrá ed. Mahwah, NJ: Erlbaum; 2005. pp. $15-50$

[20] Brown D, Brooks L. Introduction to career development: Origins, evolution, and current approaches. In: Brown D, Brooks L, editors. Career Choice and Development. 2nd ed. San Francisco: Jossey-Bass; 1991. pp. 1-12

[21] Cairo PC. Counselling in industry: A selected review of the literature. Personnel Psychology. 1983;36:1-18

[22] Saeed R, Lodhi RN, Abbas F, Ishfaque U, Dustgeer F, Ahmed M. The organizational rolein career development of employees. Management and Administrative Sciences Review. 2013;2(6):664-669

[23] O’Donnell MP. Psychologically healthy workplaces. American Journal of Health Promotion. 2007;21(3):4

[24] Blau P. Exchange and Power in Social Life. New York: Wiley; 1964

[25] Tziner A. A revised model of work adjustment, work attitudes, and work behavior. Review of Business Research. 2006;6(1):34-40
[26] Bird A. Career as repositories of knowledge: A new perspective on boundary less careers. Journal of Organizational Behaviour. 1994;15:325-344

[27] Tobing DSK. The effect of compensation, career development, work-family support on job satisfaction. Polish Journal of Management Studies [Internet]. Czestochowa University of Technology. June 2016;14(1):206-213. DOI: $10.17512 /$ pjms.2016.14.1.19

[28] Ng TWH, Eby LT, Sorensen KL, Feldman DC. Predictors of objective and subjective career success: A meta-analysis. Personnel Psychology. 2005;58:367-408

[29] Hall DT. Careers In and Out of Organisations. Thousand Oaks, CA: Sage; 2002

[30] Super DE. The Psychology of Career. New York: Harper \& Row; 1957

[31] Super DE. Leisure: What it is and might be. Journal of Career Development [Internet]. SAGE Publications. December 1984;11(2):71-80. DOI: $10.1177 / 089484538401100203$

[32] Yu C. Chinese knowledge employees' career values, perceived organizational support and career success. Business. 2011;3:274-282

[33] Ismail A, Adnan N, Bakar R. Perceived career development support in workplace career programme. Economic Annals [Internet]. National Library of Serbia; 2014;59(201):157-175. DOI: 10.2298/eka1401157i

[34] Leavitt WM. High pay and low morale: Can high pay, excellent benefits, job security, and low job satisfaction coexist in a public agency? Public Personnel Management. 1996;25(3):333-341 


\title{
Chapter 3
}

\section{Significance of Soft Skills in Career Development}

\author{
Mitashree Tripathy
}

\begin{abstract}
Over the years, the world has come closer, and workplaces have developed aggressively because of globalization. It has been critically vital and mandatory to deliver an advanced level of workplace excellence. Fast-paced competition is evident everywhere especially at workplaces. Many business organizations have called for survival of the fittest which is not only essential but also the key constraint today by business organizations. At this explicative point, the question arises is how to stay ahead of competition, concurrent to this speedy development, and how to survive and sustain this competition. Studies argue that employees at workplaces must acquire skill sets besides their domain skills that can intervene in their career growth and help them grow. This paper examines the significance of soft skills at workplaces and typically focuses on selected soft skills like positive attitude, communication skills, maintaining work ethics, teamwork abilities, and time management skills to be surpassingly requisite to enhance career perspectives.
\end{abstract}

Keywords: soft skills, communication skills, positive attitude, teamwork, strong work ethics, time management skills

\section{Introduction}

We all might have encountered employees at workplaces who drop in every now and then to their fellow colleagues chamber to gossip, or who absolutely have no sense to dress formally or during occasions, or who have always been pessimistic in their approach toward a solution, or who always communicate aggressively with peers and others depicted through verbal or nonverbal means, or who keep waiting for the deadlines to approach and then begin their work given, or who use unethical means to achieve success faster. These are just the examples of some poor soft skills basically witnessed at workplaces. Thus if we considered the opposite of these examples, we are actually talking about skills and abilities that refer to as soft skills. These skills are essential to focus for both individual and career development. Literature does not provide any concrete definition of soft skills; rather it offers a list of examples of soft skills for the readers so that they can frame their own interpretation. To create an understanding of soft skills, it must first be accepted that soft skills are commonly used interchangeably with life skills, people skills, interpersonal skills, communication skills, workplace skills, cultural skills, management skills, and employability skills. "Whatever the name, it is almost essential that you have to communicate or interact in public at some point or the other. Whether it is presenting your project work, interacting with your bosses, clients or teachers, appearing for group discussions or job interviews, or excelling in the real world, 
people from all streams need the all important soft skills" [1]. Thus, soft skills can be very much related with personality traits including social and emotional intelligence that directly or indirectly affects our behavior in either developing or decaying relationships. Recent studies claim that soft skills are considered to be one of the most emerging studies in the recent decades and are exceptionally prerequisite chiefly in the domain of workplaces.

\section{Literature review}

The concept of soft skills originated way back in 1918 when Charles Riborg Mann in a bulletin of $A$ Study of Engineering Education issued along with other representatives of Carnegie Foundation for the Advancement of Teaching mentioned about the first meeting of the Joint Committee of the National Engineering Studies. In the meeting, many engineers were interrogated pertaining to their skills and abilities considered that are potential in ascertaining success in building engineering profession. Further analysis stated that personal qualities like common sense, ethics, self-competence, and emotional intelligence are universally recognized as being equally important to a professional engineer as are technical knowledge and skill.

Later, it was viewed that soft skill as a study is not restricted to only the engineering field. Emerging studies found the relevance of soft skills appeared in various domains like management, IT, education, administration, hospitality, medical, and pharmacy. Trading the application of soft skills at workplaces has gained enough attention, and the need to inculcate these skills into one's personality has become a necessity. "Whether you work in the IT industry or manufacturing industry, whether you work in a family business or a multinational corporation, soft skills are those skills that are absolutely essential for success" [2]. Furthermore, the significance of soft skills in various areas have also emphasized that there are various kinds of soft skills highly vital and valuable at workplaces. Every day, countless meetings, trainings, and business dealings are carried out at workplaces where people from diverse backgrounds work together for a common purpose through execution of ideas and information in the best possible manner. The role of soft skills at this expository situation carries enormous value.

Many authors studying soft skills state that these "are essentially people skillsthe non-technical, intangible, personality-specific skills that determine one's strengths as a leader, listener, negotiator, and conflict mediator" [3]. Alex further elucidates that there is another set of skill known as hard skills that are associated with domain skills or technical skills and that they are way different from soft skills. He clarifies that hard skills "are more along the lines of what might appear on one's resume- your education, experience and level of expertise" [3]. In other words hard skills are the technical abilities that are earned through education, training, and practice in the name of a degree. But a degree is simply not enough today to ensure a successful career. Recruiters today are seeking for work-ready candidates possessing a number of skills required specifically for specific job roles. Hence, it is true that since the growing importance of soft skills is largely accepted, "hard skills alone might not be sufficient in order to survive successfully" [4]. But the fact that both hard skills and soft skills complement each other is also not false.

Soft skills are in fact healthy supporters of communication and performance. They are recognized as connectors that build the gap and bridge relationships among the people at the workplace, leading to better productivity and performance. Soft skills reduce the gaps across various departments in an organization, thus promoting effective communication and performance. Globalization has augmented 
the changing environment at workplaces that significantly stipulate soft skills; otherwise surviving and sustaining would remain just a distant dream far from reality.

Although there are many business guides like Simplicable that distinguishes around 87 soft skills under various other subskills like leadership, communication, personal skills, interpersonal skills, and many more, this paper deals with the study of selected soft skills which are critical and must haves by the employees at workplaces to develop their career.

\section{Soft skills at workplaces}

Soft skills are familiar terms in the everyday life, in preserving interpersonal relationships, in shaping activities, and in building strategies for success; its insinuation is predominantly found at workplaces. However, for many leaders at the workplace, soft skills are believed to be unnecessary as they follow a common belief that when people are paid for their work, gratitude does not carry any stance. They fail to understand that lack of appreciation and gratitude signifies lack of skills in an employee and that lack of skills results to lack of motivation to develop personality and career at the workplace. To grow professionally in one's related field and also professionally, it is very much essential to create healthy workplace relationships with peers, clients, customers, and others who are associated with the workplace. Career development can be blocked by the lack of ability to gel up with people. Employees might be at the peak of their careers, but if they show lack of essential soft skills, they may very much land on to the bottom from where they had begun. Incorporating soft skills at the workplace helps employees discover what they lack and own, their strengths and weaknesses, and how they can use it to deal with those infinite challenges and accomplish achievements that come their way during career advancement. Soft skills thus offer essential factors to influence success to the employees in reaching their career plateau. It would also be apt to mention here that a healthy mindset is very much essential to gain influence in growing. Cultivated by emotional balance, the healthy mindset is in fact the key motivator to either progress or procrastinate in career advancement. "Happiness and emotional balance influence your career. Balanced people get more things done in higher quality. If you are lacking emotional balance, most of career strategies may not work for you" [5]. Studies conducted by "National Business Survey" from the Canadian Education and Research Institute for Counseling (CERIC) on 500 employers based on the requirement of soft skills at workplaces suggest a number of soft skills on the basis of occupation and profession and conclude that positive attitude, communication skills, teamwork skills, and strong work ethics are few among the many skills that employers consider important [6]. This paper studies in detail and describes the aspects of selected soft skills for career development. This paper includes positive attitude, communication skills, maintaining strong work ethics, teamwork, and time management skills to ensure a successful career development.

\section{Positive attitude}

Positive attitude toward work recognizes an employee's attitude toward work. It lets the employee hold a higher degree of competence and distinction toward work. Positive attitude in other words is an expression that seeks personal fulfillment through reflecting and determining accomplishments. "A positive attitude is one of the most important factors that influence a person's success" [7]. As it is positive 
attitude that determines how committed and diligent an employee is toward work, an employer would see this as helpful in career augmentation. Executed by positive thinking, positive attitude develops enthusiasm, willingness to learn, and as a result greater appreciation of results at work. This is contagious as it influences and spreads positive energy for igniting a winning spirit for all the members in a team in particular and organization as a whole. Although knowledge and talent are essential factors to succeed, attitude interlinks both factors and enhances connectivity both with people and work. Positive thinking "begins with having confidence in oneself. Confidence reinforces ability, doubles energy, buttresses mental faculties, and increases power" [8].

The beneficial impact of displaying positive attitude at the workplace has innumerable advantages of uplifting new possibilities and opportunities in terms of power and position. The right attitude consistently creates big differences, generating fine relationships which further generate better work culture and achieving goals. Right attitude is an attitude that tends to "focus on the positive, are willing to work as part of a team, and strive to be a can do person" [9]. A positive-spirited environment constructs high morale and result-driven teamwork. Feeling positive and confident on both positive and negative thoughts occupy a similar space in mind. Thinking negative would result in negative feelings with obviously negative results. But practicing positive thoughts will develop a strong sense of competence that regardless of what difficulties may arise, one will be able to defeat them. Hence it is entirely on the thoughts that control attitude.

\section{Communication skills}

Career development begins with good communication skills. The ability to communicate is one among the many steps to succeed in a career. Without sufficient skills to communicate, it becomes difficult to gain, hold, or enlarge interpersonal relationships especially at workplaces. Communication is the very lifeline of workplaces that involves a large number of people associated both internally and externally with an organization. Communication binds them all. Studies believe "there is considerable evidence to suggest that those who lack a range of well-developed communication skills find it difficult to advance their careers" [10]. Good communication delivers messages with clarity and responsibility to the receiver without any distortion or confusion. Hence, it is of utmost importance that the message transmitted must be efficiently spoken and fittingly listened and comprehended. Besides speaking and listening, reading and writing too are essential components of communication skills.

Communication cultivates motivation. Researches claim "communication should be regarded as a transaction in which participants create meaning together in an atmosphere of trust" [11]. Communication should be such that clarifies instructions, suggestions, ideas, information, and persuasions, keeping in view that the receiver understands it. When communication is clear, employees get to know what is to be done and what more can be done to improve their performance. The goals get stimulated by desired behavior through motivation. In fact, "because motivation theory is so difficult to implement, more and more companies are seeing that the link between motivation and performance improvement is communication" [12]. Communication also happens to be the main procedure to encourage and assess decision-making. Viable communication, henceforth, is a craftsmanship and thus should be incorporated at working environments for fine outcomes and achievements of objectives. Effective communication generally corrects mistake if any and provides predominant holding among everybody in the working 
environment and resolves clashes. Studies recommend that more than encoding, decoding the correct message is of prime significance to proceed with the communication procedure.

Besides verbal method, communication can also take place nonverbally that is without words. According to Susanne Jones, Associate Professor of Communication Studies at the University of Minnesota, "about 65 to 75 percent of all communication is nonverbal in nature" [13] which is why "non verbal communication forms an essential component in building successful interactions with people. One of the distinct features of non verbal communication is that it is preeminent than verbal communication" [14].

Body language like posture, gesture, facial expression, and appearance while interacting or not interacting becomes largely pivotal during communication especially at workplaces. Let us take, for example, if someone tends to avoid eye contact or maintains physical distance, it may clearly signify avoidance. However, it may not as well be true. There is a possibility that he/she may be an introvert. Hence in this situation the case is highly misjudged. Apart from body language, paralinguistic features like pitch, voice, tone, and pace also matter. A rough tone may indicate rudeness or arrogance even though not intending to. A soft voice indicates politeness, while a deep voice suggests dominance and so on.

Apart from nonverbal aspects that form an essential part of communication, another essential component is assertiveness that is the result of a positive flow in our thought process to communicate well with others. Assertiveness is being responsible. Sources claim that "assertive people take responsibility for expressing their opinions, and make every effort to communicate successfully even when their ideas or wishes are in conflict with the ideas of others" [15]. In fact, communication appears miniscule but is in fact a herculean task just as it has been ascertained that "taking responsibility for each other's communication is a big task which embodies many aspects like emotions, moods, interpersonal skills and many more into its circumference. Communication becomes spontaneous and the quality and mode alter at one point. Assertiveness holds consistency and never allows any fissure in communication" [16].

\section{Maintaining strong work ethics}

Understanding ethics at the most radical level means following workplace rules that further signifies "working hard, following healthy and safety rules, maintaining a clean and orderly work area and being punctual and reliable" [17]. It is of prime importance to maintain a greater level of ethics in order to grow professionally. There are instances where many people imply unethical means to get success. However, success earned through unethical means is short-lived. Being honest; stabilizing integrity, loyalty, and trust; and practicing mutual respect add value to workplace relationships and help in effective decision-making process during crucial times. Hence, ethics are mostly based on virtues and virtue ethics focused primarily on virtues or the goodness or the rightness of things, ideas, concepts, theories, or principles [18].

Strong work ethics makes workplaces act within persistent goals, set as professional standards for behavior concerned with the welfare of the organization and also of the society. Hence, abiding by the ethical codes encourages efficient work, inspires everyone to maintain self-control, motivates employees to remain loyal to their organization, and improves quality of work. Career advancement largely depends on ascertaining core values and moving ahead to work toward a cooperative and respected culture. 


\section{Teamwork}

An efficient team is an asset to an organization. In fact, "effective team has the ability to take more complex tasks and smoothes the progress of communication by providing better space for open discussion and cooperation among team members further maximizing the productivity of not only the team but also of the organization as a whole" [19]. Teamwork is working with people by offering the best of attitude, knowledge, and skills to other members of a team. While at the workplace, a team becomes an important place as it is a mixed bag of varying cultural backgrounds, varying perceptions, and differing ideas and opinions, but still it tends to bind its constituents together to work for a common purpose. While trying to fit in a team is a challenging task for many, it is also one of the inescapable situations at the workplace. What is even a more challenging task is failing to use team members effectively that "one can end career by ignoring the need for team development and camaraderie" [20]. Further, each member in a team is responsible to be able to carry, coordinate, and cooperate their duties along with others because teamwork is not a group skill rather a responsibility of each individual. Authors assertively state "team work is about cooperating with co-workers" [21]. Apparently, being a good team leader or team member both can have enormous benefits for career advancement. Better job performance by the team would lead to better job performance of the whole organization, and "the more competitive the organization, the better the chances are for job security, career advancement, salary increments, and bonuses for employees" [22].

\section{Time management}

Managing time has become one of the most important soft skills for career success and advancement. One needs to accept, grow, and go with it. There is so much to do at work like meeting deadlines, achieving targets, delivering results, and finishing assignments, all within a time period. Hence one has to manage time to create competence and efficacy in a way that maximizes profit, minimizes stress and frustration, and makes achieve targets more easily. In order to make a career growth, one has to sincerely make growth happen. "Good, effective time management is a core skill, a career skill that we all need both to make us able to perform in a current job and to enhance our career prospects" [23]. Time management involves some great techniques that enable one to utilize time effectively and perform well in career success. Tracy surmises that knowing the value of something facilitates good time managing capability. He provides example of the executives who experience stress and get annoyed with the work given to them or with their performance. However, there are executives of other kind who "put their whole heart into their work because it is a reflection of their values, seldom experience stress or burn out of any kind" [24]. With values, there emerges an intention and that keeps the employees motivated; there is a continuous flow of energy, activeness, eagerness, and innovation in doing work, and the work flows automatically within the time frame.

Effective time management enables to make good decisions and increases job satisfaction. Hence in order to practice good time management skills and to experience paramount adequacy during career growth, business organizations strictly emphasize on effective time management ability that is a way to develop and use processes and tools for maximum efficiency, effectiveness, and productivity. It involves mastery of a set of skills like setting goals and planning and also its effective use of time to achieve desired results. The main objective of time management 
is to enable an individual in remaining absorbed on the activities that are important first and that matter more than other things or activities, thus helping an individual being "aware of how to use time as one resource in organizing, prioritizing, and succeeding in a business in the context of all the competing activities of start-ups and new ventures" [25].

\section{Conclusion}

This paper is an attempt to study in detail few among the many soft skills and their significance in career development. Inculcating soft skills has become the need of the hour for working better, maximizing job performance, and improving one's career. Developing soft skills help turn adversities into opportunities that further lead to career success. Although goals may be seen harder to achieve in the beginning, through soft skills discussed in the paper, one may try to gradually overcome barriers that are responsible for career downfall. Through changing one's personality and perceptions toward work, people, and situations, one may be able to stand out from the crowd to grow in his/her success. A positive attitude, good communication skills, strong work ethics, and teamwork and time management skills, however, are not the only skills that soft skills restrict to. The present paper manifests the significance of selected soft skills in advancing a career and succeeding in this highly competitive world. The paper in a way proposes ways and manners for employees at workplaces to value the need to think positive, communicate well, rely on core values and ethics, work in team, and manage time to deal with difficult people and situations, ultimately giving them a roadmap to do well in their career. Mastering soft skills in this highly competitive world will not only help an employee stand out from the crowd but also augment wonders on relationships, job performances, and career advancement.

\section{Author details}

Mitashree Tripathy

FMS, Sri Sri University, Odisha, India

*Address all correspondence to: mitashreetripathy84@gmail.com

IntechOpen

(C) 2020 The Author(s). Licensee IntechOpen. This chapter is distributed under the terms of the Creative Commons Attribution License (http://creativecommons.org/licenses/ by/3.0), which permits unrestricted use, distribution, and reproduction in any medium, provided the original work is properly cited. (cc) BY 


\section{References}

[1] Sharma P. Soft Skills Personality Development for Life Success. New Delhi: BPB Publications; 2018

[2] Ramesh G, Ramesh M. The ACE of Soft Skills: Attitude, Communication and Etiquette for Success. Dorling Kindersley (India): Noida; 2010

[3] Alex K. Soft Skills: Know yourself \& Know the World. New Delhi: S. Chand \& Company Ltd.; 2012

[4] Bhatnagar N, Bhatnagar M. Effective Communication and Soft Skills: Strategies for Success. Delhi: Pearson Education; 2012

[5] Nagy Z. Soft Skills to Advance your Developer Career: Actionable Steps to Help Maximize your Potential. Berkeley, CA: Apress; 2019

[6] Valdez N. How hard is it to Find Employees with Soft Skills? 2015. Available from: https://ceric.ca/ $\mathrm{fr} / 2015 / 01 /$ how-hard-is-it-to-findemployees-with-soft-skills/ [Accessed: 28 May 2020]

[7] Masters LA, Wallace HP. Personal Development for Life and Work. Mason, OH: South Western CENGAGE Learning; 2011

[8] Fritz R. The Power of a Positive Attitude: Discovering the Key to Success. Netherlands: Amacom; 2008

[9] Casto ML. Get Smart! About Modern Career Development: A Personal Guide to Creating your Lifes Work. Atlanta, GA: Get Smart! Pub; 2000

[10] Ellis R. Communication Skills:

Stepladders to Success for the Professional. Bristol, UK: Intellect; 2009

[11] Fielding M. Effective Communication in Organizations. Cape Town: Juta Academic; 2006
[12] Vanita. Effective Communication in Human Resource Development. New Delhi: Atlantic; 2003

[13] Schwartz LC. Nonverbal Communication With Workplace Interactions. 2017. Available from: https://smallbusiness.chron.com/ nonverbal-communication-workplaceinteractions-844.html [Accessed: 28 May 2020]

[14] Tripathy M. Understanding the non verbal components of cross cultural communication: A perspective of soft skills. International Journal of Humanities and Social Science Invention. 2017;6(9):82-88

[15] Schwartz AE. Assertiveness: Responsible Communication. USA: A.E. Schwartz and Associates; 2003

[16] Tripathy M. Assertiveness - A win-win approach to business communication. IUP Journal of Soft Skills. 2018;12(2):48-56

[17] Harwood L. Your Career: How to Make it Happen. Mason, $\mathrm{OH}$ : South-Western/Cengage Learning; 2013

[18] Tripathy M. Virtue ethics: A companion to preserve dignity in teaching profession. The International Journal for Ethics Education. 2020;5(1):115-122. DOI: 10.1007/ s40889-020-00090-3

[19] Tripathy M. Building quality teamwork to achieve excellence in business organizations. International research. Journal of Management, IT and Social Sciences. 2018;5(3):1-7. DOI: $10.21744 /$ irjmis.v5i3.662

[20] Dimartile D. Understanding the Secrets to Career Advancement: Through the Eyes of an Hr Director. Bloomington, IN: Iuniverse Inc.; 2012 
Significance of Soft Skills in Career Development DOI: http://dx.doi.org/10.5772/intechopen.89935

[21] Flores LG. Executive Career Advancement: How to Understand the Politics of Promotion: The X Factor. Bloomington, IN: Authorhouse; 2009

[22] Goetsch DL. Taking your Faith to Work: How Christians Can Succeed In Secular Careers. Powder Springs, GA: American Vision Press; 2008

[23] Forsyth P. Successful Time Management. Great Britain: Kogan Page; 2007

[24] Tracy B. Time Management (the Brian Tracy Success Library). Netherlands: Amacom; 2014

[25] Marvel MR. Encyclopedia of New Venture Management. Thousand Oakes: Sage; 2012 



\title{
Job Training Satisfaction, Job Satisfaction, and Job Performance
}

\author{
Wen-Rou Huang
}

\begin{abstract}
Training is an important ongoing investment in human assets to assist employees in learning skills and acquiring knowledge to achieve organizational goals. To maximize training effectiveness, three major activities of needs assessment, program design and delivery, and training evaluation need to be well-prepared to make trainees be satisfied with the training. Job training satisfaction proposed by Schmidt in 2007 was defined as how people feel about the aspects of the job training they receive in the workplace. Research has shown that well-designed and prepared training activities in a training program will result in job training satisfaction (JTS), which then influences employee's work-related attitudes such as job satisfaction (JS). This will further affect their intentions of turnover and job performance. Thus, in this chapter, the fundamental concepts of training, job satisfaction, and job training satisfaction will be introduced. The key factors and models to develop successful training programs will be presented. The relationships between training, job training satisfaction, job satisfaction, and job performance will be elaborated. The purpose of this chapter elucidates the importance of JTS, which human resource practitioners should always bear in mind when designing and delivering a training program.
\end{abstract}

Keywords: training, training effectiveness, job training satisfaction, job satisfaction, job performance

\section{Introduction}

Nowadays, organizations are facing a lot of challenges when competing in various sectors of the global market such as economics, technology, and labor. One of the crucial strategies for an organization to gain competitive advantage is exploitation of training. In particular, training is an important function for an organization to cultivate employees' explicit and implicit knowledge, skills, and abilities and transfer employees into the valuable resources of an organization. This function is not only linked to improvement of business performance but also an effective determinant in shaping employee attitudes, which are critical variables to influence job performance [1]. According to the literature, job satisfaction is defined as "a pleasurable emotional state resulting from the appraisal of one's job or job experiences" ([2], p. 94). It is one of the major job attitudes to affect employees' behaviors and shows a strong relationship with other affective outcomes such as learning motivation, turnover rate, and firm performance [3]. 
Since training and job satisfaction are two important variables which individually produces impacts on firm performance, this chapter aims to elaborate training in organization toward job satisfaction. This chapter is organized in four sections. The first section describes how to plan and carry out an effective training program. It begins by discussing the definition of training and the meaning of learning. Next, a training effectiveness model is constructed to present a whole picture about the factors which influence the training outcomes. Elucidation will be provided for each part of the model which includes individual characteristics, organizational characteristics, and task characteristics, followed by needs assessment, training design, and training evaluation. The second section focuses on job satisfaction in which the fundamental concepts are introduced. This is followed by discussion of the impacts of job satisfaction on job performance. The third section describes job training satisfaction and how it contributes to job satisfaction, job performance, and other work-related attitudes. The final section is Conclusions.

\section{Training}

\subsection{Training and learning}

What is training? Training refers to "a planned effort by a company to facilitate employees' learning of job-related competencies" ([4], p. 5). It is also defined as “a planned and systematic effort to modify or develop knowledge, skills and attitudes through learning experiences to achieve effective performance in an activity or a range of activities" ([5], p. 41). Training is the major means to be used by organizations to cultivate employee competence to reach the appropriate required levels. It is also an important business strategy for organizations to cope with a variety of forces affecting the workplace $[6,7]$. It is stated that training is organized and used by an organization as a business strategy to help employees develop and acquire competence, which includes knowledge, skills, behaviors, and attitudes that are critical for successful job performance. Typically, training can be distinguished by two basic types of locations where it is conducted, i.e., off-the-job and on-the-job. Off-the-job training provides learning opportunities on a variety of topics at a site other than where the work is actually done, whereas on-the-job training (OJT) occurs in the work setting itself [6]. With the assistance of modern technology, online training can be realized as well [8]. No matter which sites or ways the training is conducted, the key to effective training is to activate learning to occur.

In most of the textbooks, learning is defined as an effect of experience on behavior [9]. It is related to a process of change in behavior that is due to experience. Actually, all learning involves two processes: one is an external interaction process between the learner and his or her social, cultural, and material environment, and the other is an internal psychological process of elaboration and acquisition in which new impulses are connected with the results of prior learning [10]. However, if the outputs of learning process (either through external or internal) only produce change in people's behavior, such a definition cannot be satisfied by many researchers [9]. Therefore, learning has also been defined as "a relatively permanent change in human capabilities that is not a result of growth processes" ([4], p. 140). Based on this definition, learning can bring out three different outcomes. The first one is the content dimension, which refers to knowledge, understanding, skills, abilities, and attitudes. The second one is the incentive dimension which includes emotion, feelings, motivation, and volition. The final one is the social dimension, which involves interaction, communication, and cooperation [10]. Learning, thus, can be further referred to as a process that is "seen" through changes in knowledge, skills, 
attitudes, behaviors, emotion managing ability, communication style, and more during training and generalization to the transfer context.

Traditionally, in the workplace, learning occurs through formal training and development. All formal learning activities are designed with specific learning objectives to cultivate employees in lifelong processes for ongoing development and acquisition of competencies to meet the challenges that the organization faces from its internal and external environment [8]. Typically, such learning is activated through direct instruction, which engage learners in lectures, discussions, simulations, role-plays, and other structured activities [11]. With technological advancement and intense competition, training scholars have claimed that employees must extend their learning outside the formal classroom or work settings to ensure competencies are maximized [12]. Thus, informal learning becomes important because it represents the most part of learning occurring in organizations. Watkins and Marsick characterized informal learning as a process "based on learning from experience, embedded in the organizational context, oriented to a focus on action; governed by non-routine conditions; concerned with tacit dimensions that must be made explicit; delimited by the nature of the task, the way in which the problems are framed, and the work capacity of the individual underlying the task; and enhanced by proactivity, critical reflectivity, and creativity" ([13], p. 287). It is unstructured and occurs outside a learning institution [11].

Figure 1 shows the relationships between training and learning. Training, either off-the-job, on-the-job, or online, involves transferring expertise and knowledge from experts who have it to novices who need it [14]. Both training and learning activities consist of a process of knowledge sharing, which is an element of reciprocity and is a giving-taking exchange process of information or assistance to others [15]. Knowledge sharing between employees and across teams allows an organization to exploit existing knowledge-based resources and has been identified as a positive force in creating innovative organizations [15-17].

\subsection{Model of training effectiveness}

In a competitive environment, while employee training and learning have become an increasingly important strategic issue for organizations [8], the core concern is how to help the company and trainees receive benefits from the training activities? The related questions include "what kind of factors that may affect the success and effectiveness of training" and "what/how trainers can do to make training program effective?” Training effectiveness, according to Noe ([4], p. 216), refers to "the benefits that the company and trainees receive from training." It focuses on understanding the whole learning system to determine why learners learn or do not. It also explains why the learning results happen and assists training

Society

\begin{tabular}{|c|c|c|}
\hline \multicolumn{3}{|c|}{ Organization } \\
\hline $\begin{array}{l}\text { Training (Trainer) } \\
\text { - A planned effort }\end{array}$ & Knowledge Sharing & $\begin{array}{l}\text { Learning (Learner) } \\
\text { - Content }\end{array}$ \\
\hline $\begin{array}{l}\text { - Job-related competencies } \\
\text { - Off-job, On-the-job, On-line }\end{array}$ & Feedback & $\begin{array}{l}\text { - Interaction } \\
\text { - Formal vs. Informal }\end{array}$ \\
\hline
\end{tabular}

Environment

Figure 1.

The relationships between training and learning. 
designers to make troubleshooting to improve training [18]. Thus, theoretically, training effectiveness is the study of the individual, training, and organizational characteristics that influence the training process before, during, and after training [18]. Training effectiveness differs from the training evaluation. Training effectiveness is a theoretical approach to understand learning outcomes, whereas training evaluation is a methodological approach to measure these learning outcomes [18]. A summarized model of training effectiveness is presented in Figure 2 [19]. Figure 2 shows the factors that impact the training outcomes and job performance and the relationships between them. Three major topics will be discussed, that is, needs assessment before training (shaded with gray color), program design and delivery during training (shaded with orange color), and training evaluation after training (shaded with pink color).

\subsubsection{Before the training: needs assessment}

Effective training practices involving the use of a training design process begin with a needs assessment $[4,8,18]$. A need is a measureable gap between two conditions-what currently is and what should be [20]. In order to define the gap of need in training, a complete assessment process should be conducted to figure out problem areas, issues, or difficulties that should be resolved [20]. Thus, a training needs assessment refers to the process used to determine whether training is necessary and why specific training activities are required $[4,8]$. In most contexts, a needs assessment focuses on gaps rather than solutions [20]. Theoretically, it involves three levels of analysis: organizational analysis, person analysis, and task analysis. Organizational characteristics, individual characteristics, and task characteristics are factors to be considered for three levels of analysis in the beginning of training design. The purpose of these levels of analysis is to realize the gaps in current training programs and further to collect information for program design and problem-solving $[4,8]$.

In Figure 2, the first factor is organizational characteristics. Organizational characteristics include organizational structure, business strategies, support of

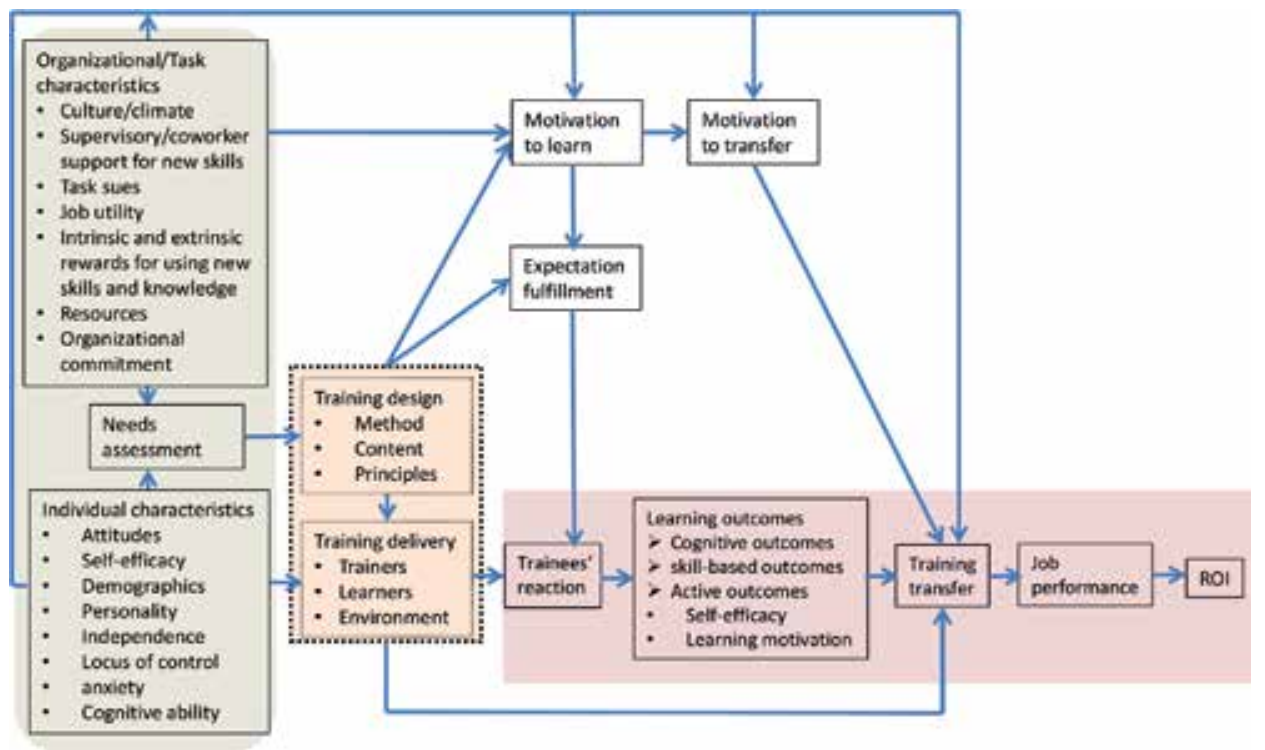

Figure 2.

The comprehensive model of training effectiveness. 
managers for training activities, training resources, organizational procedures, reward systems, culture, and climate $[4,8,18,21]$. Each variable plays a very critical role to impact training effectiveness. For example, Facteau et al. [22] found that intrinsic and compliance incentives, organizational commitment, and social support for training are able to predict trainees' pretraining motivation. Motivation is the key determinant of the choices individuals make to engage in, attend to, and persist in learning activities, which will affect learning performance [3]. Because organizational analysis is concerned with identifying whether (1) training fits the company's strategic objectives; (2) training supports the company's culture, climate, and policies; and (3) the company has the budget, time, and expertise to carry out training, this analysis is usually conducted in the first place [4]. Several major questions will be assessed in this analysis: "How does the training relate to business objectives?" "How does training support business strategy?" "What are the threats to the talent base?" "How does the training impact day-to-day workplace dynamics?" "What are the costs and expected benefits of the training?" $[4,8]$.

Another factor, individual characteristics, includes cognitive ability, attitudes, locus of control, personality, anxiety, age, self-efficacy, expectations, job involvement, pretraining motivation, need for achievement, independence, and more $[18,19,23]$. A large number of studies have been demonstrating how individual differences influence transfer of learning and learning performance, which further impacts on training effectiveness [7, 24]. For example, Noe showed that individuals with an internal locus of control had more positive attitudes toward training since they viewed training as a means to help them receive tangible benefits [25]. Mathieu et al. proposed that trainees with high achievement motivation were more motivated to learn and perform well in the training program [26]. Klein et al. found that the learners with high learning goal orientation (LGO) would be significantly related to the factor of motivation to learn [27]. Macey and Schneider claimed that four individual characteristics like positive affectivity, proactive personality, conscientiousness, and autotelic personality were more likely to have greater psychological availability to learn and also perceived learning activities being more meaningful such that they are likely to participate actively in the training activities [28]. In addition, many researches have suggested that learning is negatively related to aging [24]. Also, three of the big five factors-conscientiousness, neuroticism (emotional stability), and openness to experience-significantly impact learning, training, and transfer outcomes [29]. Since employees' individual characteristics make huge impacts on learning performance, personal analysis helps to identify employees' characteristics and readiness for training and recognize who needs training and who will perform well in the training program.

The third factor, task characteristics, consists of the knowledge, skills, and abilities required to complete the tasks, the equipment, and environment that the employee works in, time constraints for a task, safety considerations, or performance standards [4]. Thus, for task-level assessment, it involves checking specific duties and responsibilities assigned to various jobs and the types of skills and knowledge needed to perform each task [8]. In other words, the major purpose of task analysis is to collect job-related information to identify the task and the training that employees will require in terms knowledge, skills, and abilities. This analysis should be conducted only after the organizational analysis because it is a time-consuming process to gather and summarize data from persons in different layers of the company [4]. Several questions will be addressed in this analysis. For example, what kinds of responsibilities are to be assigned to the job? What are the skills or knowledge needed for successful performance? What are the implications of mistakes? What tasks should employees be trained $[4,8]$ ? 


\subsubsection{During the training: training design and delivery}

After identifying the gaps and training objectives through the needs assessment, the next step is the design and delivery of the training itself [8]. Program design is rooted in learning theories and refers to "the organization and coordination of the training program" ([4], p. 172). More specifically, "it is a process for helping to create effective training in an efficient manner. It is a system that helps designers ask the right questions, make the right decision, and produce a useful and useable product as the situation requires and allows" [30]. Thus, the purpose of a program design is to make learning occur and training effective. Research has indicated that each element of training design process is related to the quality of training. Researchers such as Baldwin et al. and Klein et al. presented that training design with organizational characteristics and individual characteristics together influences trainees' motivation to learn and, motivation to transfer, and real training transfer [27, 31]. Latif presented a model of training effectiveness which points out that training satisfaction comes from trainees' feeling of satisfaction with training session, training content, trainers, and learning transfer [1]. Noe et al. also showed that technology-based and face-to-face learning methods and contextual factors such as organizational climate, interpersonal dynamics, and individual differences are able to promote psychological engagement in learning, which is a crucial factor to enhance the effectiveness of training, development, and related learning activities [7].

Training methodology was also found to be an important factor in the equation of job training satisfaction [32]. Compared to other training methods, on-the-job training is one of the oldest, most widely used training methods in the workplace. It can be useful for training newly hired employees, orienting promoted or transferred employees to the new job positions, upgrading employees' competencies when new technology is used, and delivering cross-culture training to employees who are assigned to work overseas [4]. Since OJT occurs at or near the workplace using actual equipment and tools, most of the time, trainees are highly motivated to learn and can be customized to the experiences and abilities [4]. Although there are many advantages, OJT is informal or unstructured in nature and has received serious criticism such as incomplete and unpredictable [33]. Thus, structured on-the-job training (S-OJT) was proposed by Jacobs and McGiffin [34]. In contrast to informal and unstructured OJT, structured OJT adopts a planned approach to train and develop employees' competencies [33]. Many research results indicated that S-OJT is superior to unstructured on-the-job training in terms of having lower training cost, enhancing skills acquisition, and removing learning anxieties [6].

In the past, a large portion of the research in program design has paid great attention to traditional instructional design (ISD) model, which includes conducting a needs assessment, setting the objectives of training, identifying evaluation criteria, selecting appropriate trainers and training methods, making meaningful materials, and properly coordinating and arranging training delivery. In addition, it involves ensuring training transfer, offering a good training site, and providing opportunities for practice and feedback $[4,7]$. Although the traditional instructional design brings a lot of benefits to enhance training effectiveness, it is more instructor-oriented where lecture proceeds with adding sophisticated elements and feedback loop with interaction and communication [35]. Some scholars have recently claimed that instructor-oriented design is deemed to be disadvantageous for effective learning. They argued that the learners in instructor-centered program may be passive in learning activities and seldom grasp the significance or realize the intricacies of the model from the instructors during the training $[16,35]$. Thus, it has been claimed that the instructional design model needs to be modified or 
adapted to better fit the learner-centered learning, particularly technology-based learning $[16,36]$.

What is learner-centered learning? Learner-centered learning involves the balance between instructor and learner shifting the roles, so that the learners take on the responsibility to learn and the instructor becomes more of a facilitator $[37,38]$. In this learning paradigm, instead of transferring factual knowledge to the learners, the instructor focuses more on creating a learning environment and providing learning opportunities that empower learners to construct knowledge for themselves [39]. Attention, in this paradigm, is given not only to what the learners learn but also to how they learn and whether they are able to retain and apply the knowledge or not [36]. More specifically, the instructor with the role of facilitator utilizes multiple teaching methods beyond traditional lecturing to help the learners actively participate in learning [35].

Thus, several tips for delivering the training with the learner-centered approach are described as follows [36]. First, at the beginning of the training, the trainer involves learners into decision-making process for choosing the course textbook. Second, after choosing the textbooks, the trainer invites learners to pick up the topics which they are interested in and also fit personal needs. In this way, the learners would take responsibility for learning by themselves. Third, the class will be run like a discussion session. The trainer gives training materials before the class and asks them to read in advance. Following the Shor's suggestion that the trainer controls his/her "authoritative academic voice" [40], the trainer says as little as necessary and focuses on determining what they are interested in, what they have troubles with and what they want to talk about. The trainer offers questions, comments, structures, and academic knowledge while patiently listening to trainees' thoughts and ideas. The trainer and the learners learn from each other through interaction. Fourth, Weimer suggested that the careful design of assignments which help students effectively use the power they are given is the key component of sharing power to the learners [41]. Thus, the trainer needs to structure the assignments well and allows the trainees to make choices about the ways to complete the projects, for example, by conducting interview or submitting a real lesson activity.

Three critical issues must be considered in the designing and delivering stage [8]. The first one is interference. Interference occurs "when prior training, learning, or established habits act as block or obstacle in the learning process" ([8], p. 391). That is, someone who has more experience in behaving in a certain way will have more difficulties in changing the way he/she responds when encountering a situation. Therefore, when designing the training, the trainers need to be aware of this issue. The second one is transfer design [8]. Transfer refers to whether the trainee or learner can actually perform the new skills or use the new knowledge on the job [4]. Transfer design, thus, is defined as the ability to transfer learning to the job and to which the training instruction matches the job requirements [42]. In order to ensure that the organizations are able to receive benefit from training, Lim and Johnson suggested that training design, content, and instructional strategies must be related to the objective of transfer, whether near or far transfer [43]. In other words, transfer mechanisms such as climate for transfer, management and peer support, opportunity to perform, training awareness, and using self-management strategies need to be included in the design of a training program for maximizing transfer $[4,21,44]$. The third one is the needs of adult learners. It is said that the ways of children's learning are different from those of adults. Several assumptions were proposed by Malcolm Knowles [45]: (1) adults have the need to know why they learn, (2) adults have the need to be self-managed, (3) adults bring more workrelated experiences into the learning context than children or teenagers, (4) adults learn with a problem-centered approach, and (5) adults are motivated to learn by 
getting both extrinsic and intrinsic motivators. Since most of the job-related training is targeted for employees whose age is over 18, the training program must meet the needs of these adult learners in order to enhance training effectiveness.

\subsubsection{After the training: training evaluation}

Evaluation is an integral part and the final stage of most instructional design (ID) models [46]. Theoretically, it is a systematic process of collecting data in an effort to measure and determine success or failure of a training program with regard to content and design $[18,47]$. Two questions intend to be answered in the evaluation process, that is, whether (1) training objectives are achieved in the learning process and (2) accomplishment of those objectives results in enhanced job performance [48]. Thus, evaluation can be divided into two categories, formative evaluation and summative evaluation $[46,49,50]$. Formative evaluation is an evaluation with the purpose to improve design and development to enhance learning, whereas summative evaluation is intended to determine whether the training program is worthy or effective [51, 52]. Besides, Campbell stressed that the most important and fundamental thing is whether trainees have learned the materials covered in training or not [53].

Traditionally, Kirkpatrick's model was one of the first efforts to create a framework for training evaluation. It is also the simplest method to understand training effectiveness $[18,54]$. According to Kirkpatrick, training can be evaluated at four levels. Level 1 is the "reactions" criteria, which evaluates trainees' affective and attitudinal perceptions to a training program, including facilities, trainers, and content. For the "reactions" criteria, evaluation is performed via a questionnaire completed by trainees or self-reported regarding perceived learning gains [55]. Level 2 is the "learning" criteria, which evaluates the extent to which trainees have learned the training materials covered in training and acquired knowledge, skills, attitudes, and behavior from a training program. Learning outcomes are typically measured by using various forms of knowledge tests such as pencil-and-paper test or by immediate post-training measures of performance and skill demonstration in the training context [56]. Level 3 is the "behavior" criteria. It refers to as transfer criteria and evaluates the extent to which trainees have applied the learned competencies on the job. For behavioral criteria, evaluation is assessed by self-ratings, supervisor ratings, or objective performance indicators [56-58]. Level 4 is the "results" criteria, which evaluates the extent to which the training program has improved business outcomes and to increase organizational-level profits [47]. Although this kind of assessment is the most difficult to be obtained, it is highly desirable for the organizations. Most of the time, "results" are operationalized by productivity gains, reduced costs related to employee turnover, increased customer satisfaction, enhancing employee commitment, or increase in profitability [57, 58].

Although Kirkpatrick's framework is the most accepted approach for training evaluation, it has been criticized by many scholars. One of the criticisms is that the criteria used for evaluation in Kirkpatrick's framework do not relate to the training needs, the learning objectives, and strategic goals of the organizations [4]. The second one is the lack of relationship between reaction, learning, behavior, and results' criteria [55]. As a result, both training practitioners and academic researchers have developed a more comprehensive model for training criteria. For example, Kraiger et al. attempted to expand the original Kirkpatrick model by linking the learning outcomes with training evaluation [48]. Based on Kraiger et al's proposition, three categories of learning outcomes, that is, cognitive, skill-based, and affective outcomes, should be included in evaluation $[48,59]$. Specifically, cognitive 
outcomes are used to determine the degree to which trainees are familiar with principles, facts, techniques, procedures, or processes emphasized in the training program. It includes verbal knowledge, knowledge organization, and cognitive strategies. Skill-based outcomes, including skill learning and skill transfer, are used to assess the level of technical or motor skills and behaviors. Affective outcomes include both attitudinal and motivational change, which also involves disposition, motivation to learn, self-efficacy, tolerance for diversity, safety attitudes, customer service orientation, and goal setting $[4,48]$.

Among three categories of learning outcomes, affective outcomes have attracted a lot of attentions in different research areas such as education, psychology, and organizational behavior. The scholars are particularly interested in the issue regarding whether self-efficacy or motivation to learn can be changed through training and how different training methods impact self-efficacy and motivation to learn. For example, Gist found that a training method comprising cognitive modeling with practice and reinforcement generated significantly higher participant self-efficacy than a method involving only lecture and practice [60]. Torkzadeh and Dyke suggested that training significantly improved Internet self-efficacy for trainees, both males and females [61]. Combs and Luthans stated that the diversity training enhanced trainees' diversity self-efficacy [62]. Huang and Jacobs claimed that structured on-the-job training could generate higher self-efficacy to achieve training outcomes than classroom training with lecture only, especially for trainees with lower general self-efficacy (GSE) [63]. Huang and Jao reported that structured on-the-job training could generate higher trainees' motivation to learn than classroom training [64].

\section{Job satisfaction and job training satisfaction}

\subsection{The definition of job satisfaction}

Among thousands of attitudes, job satisfaction is one of important workrelated attitudes in the work environment [3]. Specifically, job satisfaction refers to the degree to which the feeling of satisfaction is derived from the employees' perceptions toward different facets of their tasks or jobs $[65,66]$. In other words, job satisfaction is a pleasurable or positive emotional state emerging as the result of appraising one's job or job experiences and as the fulfillment or gratification of certain needs that are associated with one's work $[3,67,68]$. Simply put, job satisfaction is the combination of feelings, beliefs, and behavioral intentions that workers hold a relation to their current jobs $[3,69]$. The employees' job satisfaction is measurable and can be changed [3]. A popular way to explain job satisfaction has been the person-environment fit paradigm, which suggests that the more a person's work environment is fulfilling one's needs, personality, values, or personal characteristics, the greater the degree of job satisfaction is [70].

\subsection{Factors to influence job satisfaction}

While tackling the issue of job satisfaction, some typical questions were raised by researchers. For example, why are some employees more satisfied than others? What kinds of work tasks are especially satisfying? How to design a task to make employees feel satisfied? Colquitt et al. claimed that values play a key role in explaining job satisfaction [2]. What is value? Values are "the things that people consciously or unconsciously want to seek or attain" ([2], p. 94). Thus, value-percept theory argues that "job satisfaction depends on whether the employee perceives 
that his or her job supplies the things that he or she values" ([2], p. 94). Based on the value-percept theory, the dissatisfaction of employees can be expressed as follows:

$$
\text { dissatisfaction }=\left(\mathrm{V}_{\text {want }}-\mathrm{V}_{\text {have }}\right) \times\left(\mathrm{V}_{\text {importance }}\right)
$$

where $V_{\text {want }}$ refers to how much of a value an employee wants, $V_{\text {have }}$ is the value the job supplies, and $V_{\text {importance }}$ reflects the importance of the value to the employee. It can be seen that, although the difference between $V_{\text {want }}$ and $V_{\text {have }}$ causes the dissatisfaction, it is the importance of the value that will either magnify or minimize the dissatisfaction [2]. In the value-percept theory, five specific facets of satisfaction, i.e., pay satisfaction, promotion satisfaction, supervision satisfaction, coworker satisfaction, and satisfaction with the work itself, must be met in order to achieve overall job satisfaction.

While explaining job satisfaction from the perspective of value-percept theory, personal characteristics make the issue of "the things that each employee wants to pursue and feels important in the workplace" complicated. Personal characteristics include personality disposition, attitudes, self-efficacy, self-esteem, motivation, gender, communication style, emotions, and more [3,71]. Since each employee is independent and unique, the value of things an employee wants and their importance differ from one to another. Such differences cause the variance in dissatisfaction. Personal characteristics offer the explanation to the question of why some employees are more satisfied than others. Take personality as an example. If the employees' score is high on the neuroticism scale in a personality measurement, they are likely to carry a rather negative view toward the world. This makes them more likely be nervous, anxious, depressed, and insecure in general, especially in the workplace. Conversely, the employees who have higher scores on the conscientiousness and extraversion scales tend to be responsible, organized, gregarious, and sociable, and it is more likely they will be satisfied with their work [3]. Hence, personality traits of neuroticism, extraversion, and conscientiousness displayed appreciable correlations with the employees' job satisfaction [72].

Besides personal characteristics, situational characteristics also influence job satisfaction, which can explain what kinds of work tasks are especially satisfying. The situational factors include pay, opportunities for promotion, administration style, coworker, and working conditions [73]. For employees, a job is not "just a job.” Instead, it is a collection of tasks, relationships, and rewards. Any job-related conditions happened in the workplace may influence their emotion, which further impacts how they judge and perceive toward their job [3]. Therefore, in order for employees to have job satisfaction, the situational factors need to be carefully considered. For example, is the pay commensurate with the job duties? Is the pay secure? Are the promotions frequent, fair, and based on ability? Is the supervisor competent, polite, and a good communicator? Are the coworkers responsible, helpful, and interesting? Is the work challenging, interesting, respected? If it is yes to all the above questions, then it is highly possible that employees would be satisfied with their job [2].

The needs of employees toward the work itself can be further realized through job characteristic theory. In other words, this theory helps to answer the question of how to design a task to make employees feel satisfied. Job characteristic theory suggested that job dimensions such as task identify, task significance, skill variety, autonomy, and feedback impact employees' satisfaction with the work itself [3, 74]. Among these dimensions, skill variety, task identities, and task significance together produce a sense of meaningfulness of work, which reflects the extent the work tasks fit in the employees' value and beliefs. The dimension of autonomy allows employees to experience the responsibility for outcomes of the work. 
Responsibility for outcomes refers to the extent the employees feel that they are responsible for the quality of the work. Providing either positive or negative feedback to employees make them have the opportunities to know the actual results of the work activities. Knowledge of results means that employees know how well or poorly they are doing. Thus, research suggests that the higher the three psychological states, the higher the working motivation, which leads to higher job satisfaction. An employee who has a high level of job satisfaction holds positive feelings toward his or her job, while he/she may hold negative feelings if he/she has a low level of job satisfaction [3].

\subsection{How important is job satisfaction?}

The next question to be answered is "does job satisfaction really matter?" This question can be answered through elaborating the relationship between job satisfaction and job performance, job commitment, organizational citizenship behavior (OCB), absenteeism, and turnover.

First, a number of researchers have been curious about the relationships between job satisfaction and job performance. For this question, many people may intuitively believe that job satisfaction is an important factor to impact job performance. Their presumption is that happy workers are more likely to be productive workers. However, at the early stage, the results indicated that job satisfaction was not meaningfully associated with job performance [75]. Till recently, studies showed that job satisfaction was moderately correlated with task performance. In other words, job satisfaction did predict job performance [2]. The satisfied employees who held positive feelings toward their work did a better job to fulfill the duties [76], to increase creativity in job [77], to enhance decision-making and problem-solving ability [78], and furthermore, to strengthen the memory and recall ability [79].

Second, job satisfaction is interrelated to job commitment. Commitment is defined as that an employee identifies with a particular organization and its goals and wishes to remain as a member [3]. Commitment can be divided into three types, i.e., affective commitment, continuance commitment, and normative commitment, which are emotional-based, cost-based, and obligation-based, respectively [2]. Research found that job satisfaction was strongly correlated with affective and normative commitment but not correlated with continuance commitment [80]. Thus, the employees who have positively affective reaction to their jobs will be committed to their job and feel an obligation to remain in the organization [80-84].

Third, job satisfaction is moderately positive related to organizational citizenship behavior [2, 85]. OCB has been defined as "individual behavior that is discretionary, not directly or explicitly recognized by the formal reward system, and that in the aggregate promotes the effective functioning of the organization" ([86, 87], p. 4). Williams and Anderson found that the cognitive component of job satisfaction predicted the emergence of OCB [88], which was also supported by Moorman's study [89]. Therefore, the satisfied employees would like to engage in more workrelated behaviors to offer help to coworkers and increase desire to interact with others. OCB is extremely important for the employees to contact with the customers since it leads to improved customer evaluation of service quality [90].

Finally, job satisfaction reduces job turnover and absenteeism [91, 92]. Turnover refers to "...the voluntary and involuntary permanent withdrawal from an organization” ([93], p. 72). Since actual turnover behavior is difficult to measure, Lingard suggested using turnover intention as a predictor of actual turnover behavior [94]. Karatepe et al. found that job satisfaction was a negative association with turnover intention [95]. As to absenteeism, it refers to "unscheduled employee absences from the workplace" ([96], p. 144). Vroom found that low levels of job satisfaction 
contributed to higher absenteeism rates [97], and such a finding was confirmed by Clegg [98]. In addition, Drago and Wooden conducted a survey of 601 workers from Australia, New Zealand, Canada, and the USA and found that absenteeism was lower while employees' job satisfaction was high [99]. The relationship between job satisfaction and turnover was stronger than between satisfaction and absenteeism [3].

\section{Job training satisfaction}

\subsection{The definition of job training satisfaction}

The concept of job training satisfaction was proposed by Schmidt [32]. He combined the definitions of job training and job satisfaction into one of the affective outcomes, called job training satisfaction (JTS). As mentioned above, training involves employees acquiring knowledge and learning skills that they will be able to apply on the job immediately [8]. Job satisfaction involves how an employee feels and what he/she thinks about the job [2]. Job training satisfaction, thus, is defined as "...how people feel about aspects of the job training they receive. Job training satisfaction is the extent to which people like or dislike the set of planned activities or dislike the set of planned activities organized to develop the knowledge, skills, and attitudes required to effectively a given tasks or job" ([32], p. 483). According to Schmidt, the definition of job training satisfaction has several key components [100]. First, the focus of evaluation is on-the-job training as a whole, rather than on a single part of training activities such as a training course, trainers, facilities, or training content. Second, it refers to a pleasurable or positive emotional state resulting from each element and the whole process before and after the job training, such as fulfillment of needs, enhancing motivation to learn, or satisfied with the transferring the learned competencies to the job. Third, the subjects of evaluation target on the trainees where formal or planned training activities are offered by the organization rather than the informal learning effort endeavors by the employees themselves. When measuring job training satisfaction, not only the employees' feelings about the job training are measured but also the training activities offered by the organization are examined $[32,101]$.

\subsection{The relationship between job training satisfaction, job satisfaction, and other work-related attitudes}

In the past, the impact of training on job satisfaction was not emphasized until it was found that job satisfaction tended to be higher where workplace training was held in organizations [102]. In order to explore the relationships between these two variables, Schmidt conducted a survey of job training and satisfaction for employees in customer and technical service department in nine major organizations in the USA and Canada to address how job training satisfaction impacts on job satisfaction [32]. According to his findings, job training satisfaction was not only highly correlated with job satisfaction but also significantly related to the time spent in training, training methodology, and content. However, it was not related to age, gender, and race/ethnicity. Extended researches have been carried out to explore the impact of job training satisfaction on other work attitudes. Huang and Su found that there is a negative relationship between job training satisfaction and turnover intentions [103]. It is stated that, when employees are satisfied with job training, they are more likely to stay in the organization and have lower turnover intentions. The research results have also indicated that the relationship between job training satisfaction 
and turnover intentions can be mediated by job satisfaction. Mansour et al. showed that there is a positive relation between job training satisfaction and normative commitment [100]. Moreover, job training satisfaction was found to be positively related to organizational citizenship behavior $[104,105]$, organizational commitment (OC), and job involvement (JI) [105]. The relationship between JTS and OCB can also be partially mediated by OC and JI [105]. From these research results, job training satisfaction is found to be able to enhance employees' work attitudes such as job satisfaction, commitment, job involvement, and organizational citizenship behavior, which leads to the increase of job performance.

Based on the above discussion, a revised comprehensive model of training effectiveness is proposed and shown in Figure 3. According to Schmidt's definition, job training satisfaction measures the employees' feelings about the whole job training activities such as identifying the training needs, designing the training program, delivering training contents, activating learning occurring, and assessing training evaluation. Thus, different from the original model shown in Figure 2, the variable of job training satisfaction was inserted after the variable of training transfer to influence job satisfaction and job performance. That is, if the learners are able to perceive positively toward training program, to learn the job required knowledge, skill, abilities, and attitudes through training, and to succeed in transferring the learned competencies to real workplace, their satisfaction level toward training program must be high. For instance, on-the-job training, especially structured OJT, has been perceived as an effective training approach to achieve transfer of training owing to its occurrence at or near the workplace using actual facilities, enhancing skills acquisition, and removing learning anxieties $[6,33]$. This allows the employees to be able to perform the job well and, in turn, feel satisfied with the training. Such high satisfaction toward job training leads to high level of job satisfaction and further results in high job performance but low turnover intention. These findings are interesting and valuable. Jones et al. ever mentioned that training can have an indirect effect on performance if it increases job satisfaction by making it easier for employees to perform the job or feel more valued [96]. From a series of studies, the

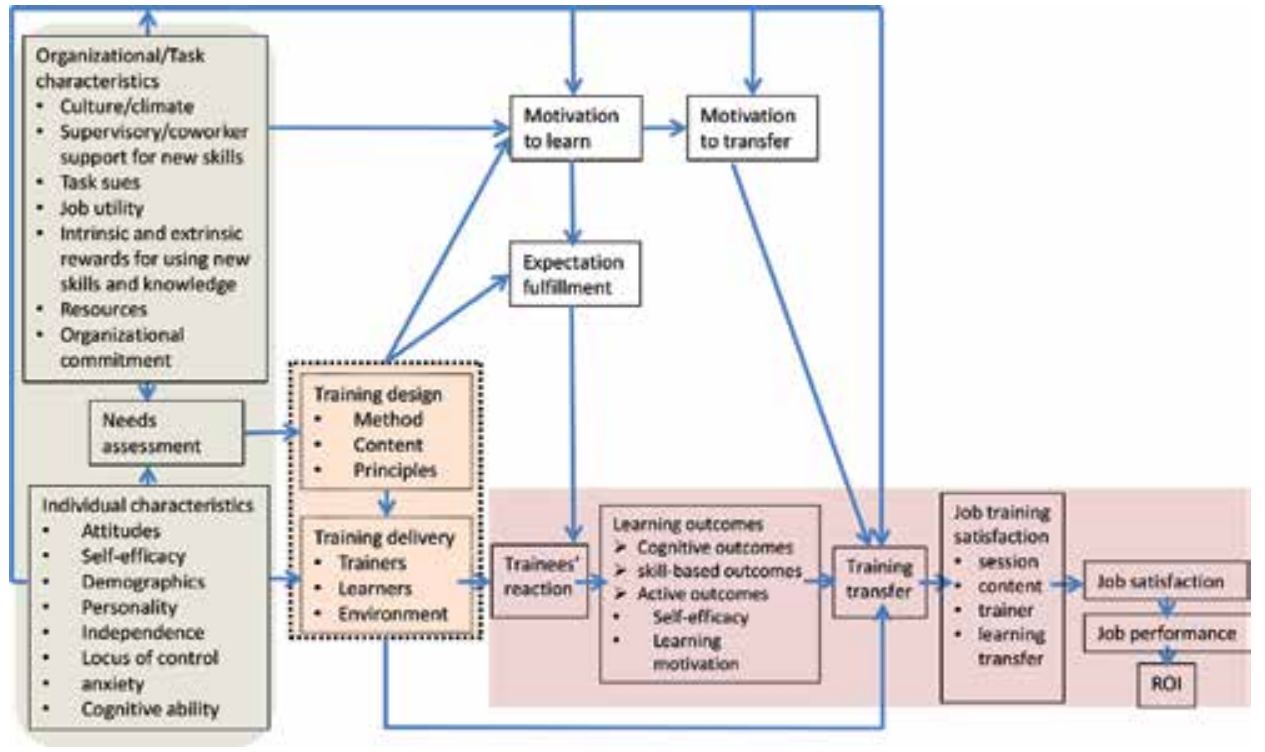

Figure 3.

The revised comprehensive model of training effectiveness with insertion of job training satisfaction and job satisfaction. 
impact of training on job satisfaction, job performance, and turnover intention has been confirmed. The variable of job training satisfaction can serve as a predictor to the employees' job satisfaction, job performance, and turnover intentions.

\section{Conclusions}

The central thesis of this chapter is to present how job training plays a role in influencing the employees' job training satisfaction, which then impacts job satisfaction and subsequently affects job performance and turnover intentions. Although training is a critical strategy to help organizations gain competitive advantages and its purpose is to help employees learn job-related competencies, job training satisfaction cannot be achieved without a well-prepared and designed training program. That is, at the beginning of the training program design, it is necessary to carry out a needs assessment to make the learning occur, which consists of organizational analysis, person analysis, and task analysis. While conducting training design and delivery during training, the learner-centered learning paradigm which has been emphasized recently may be considered as a preferred approach owing to its increasing learners' learning motivation and learning engagement. After training, the training effectiveness is evaluated by assessing not only learning performance of knowledge, skills, and job-related behaviors but also affective outcomes such as self-efficacy, attitude, and motivation. Research has indicated that possessing a pleasurable or positive emotional state with the whole job training program, employees will have higher job satisfaction and job performance. Other job attitudes such as organizational citizenship behavior, affective commitment, and normative commitment will increase, while turnover intention and absenteeism will decrease. In this chapter, the comprehensive model of training effectiveness was modified by inserting the job training satisfaction after training transfer. This not only better elaborate the relationship among training, job satisfaction, and job performance but also serves as a reminder for the human resource practitioners who should always bear in mind how to make the trainees satisfied with the training when designing and delivering a training program.

\section{Author details}

Wen-Rou Huang

Department of Business Administration, Feng Chia University, Taichung, Taiwan

*Address all correspondence to: wrhuang@gmail.com

IntechOpen

(C) 2019 The Author(s). Licensee IntechOpen. This chapter is distributed under the terms of the Creative Commons Attribution License (http://creativecommons.org/licenses/ by/3.0), which permits unrestricted use, distribution, and reproduction in any medium, provided the original work is properly cited. (cc) BY 


\section{References}

[1] Latif K. An integrated model of training effectiveness and satisfaction with employee development interventions. Industrial and Commercial Training. 2012;44(4):211-222. DOI: $10.1108 / 00197851211231487$

[2] Colquitt J, LePine J, Wesson M. Organizational Behavior: Improving Performance and Commitment in the Workplace. New York: McGraw-Hill; 2019. 548p

[3] Robins SP, Judge TA. Organizational Behavior. 15th ed. Boston: Pearson; 2013. $710 \mathrm{p}$

[4] Noe RA. Employee Training and Development. 5th ed. New York: McGraw-Hill; 2010. 589p

[5] Garavan TN. Training, development, education and learning: Different or the same? Journal of European Industrial Training. 1997;21:39-50. DOI: 10.1108/03090599710161711

[6] Jacobs RL. Structured On-The-Job Training. 2nd ed. San Francisco: BerrettKoehler; 2003. 297 p

[7] Noe RA, Tews MJ Jr, Dachner AM. Learner engagement: A new perspective for enhancing our understanding of learner motivation and workplace learning. Academy of Management Annals. 2010, 2010;4(1):279-315. DOI: 10.1080/19416520.2010.493286

[8] Mello JA. Strategic Management of Human Resources. 3rd ed. Boston: South-Western Cengage Learning; 2011. $688 \mathrm{p}$

[9] De Houwer J, Barnes-Holmes D, Moors A. What is learning? On the nature and merits of a functional definition of learning. Psychonomic Bulletin \& Review. 2013;20(4):631-642. DOI: $10.3758 / \mathrm{s} 13423-013-0386-3$
[10] Illeris K. How We Learn: Learning and Non-learning in School and Beyond. London/New York: Routledge; 2007. 289 p

[11] Burns JZ. Informal learning and transfer of learning: How new trade and industrial teachers perceive their professional growth and development. Career and Technical Education Research. 2008; (1, 22):3-24. DOI: 10.5328/CTER33.1.3

[12] Noe RA, Tews M, Michel JW. Managers' informal learning: A trait activation theory perspective. International Journal of Training and Development. 2017;21(1):1-17. DOI: 10.1111/ijtd.12092

[13] Watkins KE, Marsick VJ. Towards a theory of informal and incidental learning in organizations. International Journal of Lifelong Education. 1992;11(4):297-300. DOI: $10.1080 / 0260137920110403$

[14] Noe RA, Hollenbeck JR, Gerhart B, Wright PM. Human Resource Management. 8th ed. New York: McGraw-Hill; 2012. 758p

[15] Connelly CE, Kelloway EK.

Predictors of employees' perceptions of knowledge sharing cultures. Leadership \& Organization Development Journal. 2003;24:294-301

[16] Noe RA, Clarke A, Klein HJ. Learning in the twenty-first-century workplace. Annual Review of Organizational Psychology \& Organizational Behavior. 2014;1(1):245-275. DOI: 10.1146/ annurev-orgpsych-031413-091321

[17] Wang S, Noe RA. Knowledge sharing: A review and directions for future research. Human Resource Management Review. 2010;20:115-131. DOI: 10.1016/j.hrmr.2009.10.001 
[18] Alvarez K, Salas E, Garofano CM.

An integrated model of training evaluation and effectiveness.

Human Resource Development

Review. 2004;3(4):385-416. DOI:

$10.1177 / 1534484304270820$

[19] Cannon-Bowers JA, Salas E, Tannenbaum SI, Mathieu JE. Toward theoretically based principles of training effectiveness: A model and initial empirical investigation. Military Psychology. 1995;7(3):141-164. DOI: 10.1207/s15327876mp0703_1

[20] Altschuld JW, Watkins R. A primer on needs assessment: More than 40 years of research and practice. New Directions for Evaluation. 2014;144:5-8. DOI: 10.1002/ev.20099

[21] Kodwani AD. Decoding training effectiveness: The role of organisational factors. Journal of Workplace Learning. 2017;29(3):200-216. DOI: 10.1108/ JWL-05-2016-0038

[22] Facteau JD, Dobbins GH, Russell JEA, Ladd RT, Kudisch JD. The influence of general perceptions of the training environment on pretraining motivation and perceived training transfer. Journal of Management. 1995;21(1):1-25. DOI: 10.1016/0149-2063(95)90031-4

[23] Kontoghiorghes C. Predicting motivation to learn and motivation to transfer learning back to the job in a service organization: A new systemic model for training effectiveness. Performance Improvement Quarterly. 2002;15(3):114-129. DOI: 10.1111/j.19378327.2002.tb00259.x

[24] Colquitt JA, LePine J, Noe RA. Toward an integrative theory of training motivation: A meta-analytic path analysis of 20 years of research. Journal of Applied Psychology. 2000;85(5):678-707

[25] Noe RA. Trainees' attributes and attitudes: Neglected influences on training effectiveness. Academy of Management Review. 1986;11(4):736749. DOI: $10.5465 / \mathrm{amr} .1986 .4283922$

[26] Mathieu JM, Martineau JW, Tannenbaum SI. Individual and situational influences on the development of self-efficacy: Implications for training effectiveness. Personnel Psychology. 1993;46(1):125-147. DOI: 10.1111/j.17446570.1993.tb00870.x

[27] Klein HJ, Noe RA, Wang C. Motivation to learn and course outcomes: The impact of delivery mode, learning goal orientation and perceived barriers and enablers. Personnel Psychology. 2006;59(3):665-702. DOI: 10.1111/j.1744-6570.2006.00050.x

[28] Macey WH, Schneider B. The meaning of employee engagement. Industrial and organizational Psychology. 2008;1(1):3-30. DOI: 10.1111/j.1754-9434.2007.0002.x

[29] Holton EF III. Holton's evaluation model: New evidence and construct elaborations. Advances in Developing Human Resources. 2005;7(1):37-54. DOI: $10.1177 / 1523422304272080$

[30] Piskurich GM. Rapid instructional design. 2000. [Online] Available: http://media.wiley.com/product_data/ excerpt/10/07879472/0787947210.pdf

[31] Baldwin TT, Ford JK. Transfer of training: A review and directions for future research. Personnel Psychology. 1988;41(1):63-105. DOI: 10.1111/j.17446570.1988.tb00632.x

[32] Schmidt SW. The relationship between satisfaction with workplace training and overall job satisfaction. Human Resource Development Quarterly. 2007;18(4):481-498. DOI: 10.1002/hrdq.1216

[33] Kim JH, Lee C. Implications of near and far transfer of training on structured on-the-job training. 
Advances in Developing Human Resources. 2001;3(4):442-451. DOI: $10.1177 / 15234220122238508$

[34] Jacobs RL, McGiffin TD. A human performance system using a structured on-the-job training approach. Performance \& Instruction. 1987;26(5):8-11. DOI: 10.1002/ pfi.4160260505

[35] Smart KL, Witt C, Scott JP. Toward learner-centered teaching: An inductive approach. Business and Professional Communication Quarterly. 2012;75(4):392-403. DOI: $10.1177 / 1080569912459752$

[36] Abdelmalak M, Trespalacios J. Using a learner-centered approach to develop an educational technology course. International Journal of Teaching \& Learning in Higher Education. 2013;25(3):324-332

[37] Kahl DH Jr, Venette S. To lecture or let go: A comparative analysis of student speech outlines from teacher-centered and learnercentered classrooms. Communication Teacher. 2010;24(3):178-186. DOI: 10.1080/17404622.2010.490232

[38] Schroeder SJ. Infusing learnercentered strategies into the classroom. Occupational Therapy in Health Care. 2012;26(4):218-223. DOI: $10.3109 / 07380577.2012 .725880$

[39] Webber KL. The use of learnercentered assessment in US colleges and universities. Research in Higher Education. 2012;53(2):201-228. DOI: 10.1007/s11162-011-9245-0

[40] Shor I. When Students Have Power: Negotiating Authority in a Critical Pedagogy. Chicago: The University of Chicago Press; 1996. 257p

[41] Weimer M. Learner-Centered Teaching: Five Key Changes to Practice. San Francisco: Jossey-Bass; 2002. 258p
[42] Bhatti MA, Kaur S. The role of individual and training design factors on training transfer. Journal of European Industrial Training. 2010;34(7):656672. DOI: $10.1108 / 03090591011070770$

[43] Lim DH, Johnson SD. Trainee perceptions of factors that influence learning transfer. International Journal of Training and Development. 2002;6(1):36-48. DOI: $10.1111 / 1468-2419.00148$

[44] Chauhan R, Ghosh P, Rai A, Kapoor S. Improving transfer of training with transfer design. Journal of Workplace Learning. 2017;29(4):268285. DOI: 10.1108/JWL-08-2016-0079

[45] Knowles M. The Adult Learner. 4th ed. Houston: Golf Publishing; 1990

[46] Eseryel D. Approaches to evaluation of training: Theory \& practice. Educational Technology and Society. 2002;5(2):93-98

[47] Saks AM, Burke LA. An investigation into the relationship between training evaluation and the transfer of training. International Journal of Training and Development. 2012;16(2):118-127. DOI:

10.1111/j.1468-2419.2011.00397.x

[48] Kraiger K, Ford JK, Salas E. Application of cognitive, skill-based, and affective theories of learning outcomes to new methods of training evaluation. Journal of Applied Psychology. 1993;78(2):311-328. DOI: 10.1037/0021-9010.78.2.311

[49] Noe RA. Employee Training and Development. New York: McGraw-Hill; 2002

[50] Wang GG, Wilcox D. Training evaluation: Knowing more than is practiced. Advances in Developing Human Resources. 2006;8(4):528-539. DOI: $10.1177 / 1523422306293007$ 
[51] Scriven M. Evaluation Thesaurus. 4th ed. Thousand Oaks, CA, USA: Sage Publications; 1991. 319p

[52] Scriven M. Types of evaluation and types of evaluators. American Journal of Evaluation. 1996;17(2):151-161. DOI: $10.1177 / 109821409601700207$

[53] Campbell JP, Campbell RJ. Associates. Productivity in Organizations: New Perspectives from Industrial and Organizational Psychology. San Francisco: Jossey-Bass; 1988. 451p

[54] Bowers CA, Hitt JM II, Hoeft RM, Dunn S. Applying training evaluation models to the clinical setting. Military Psychology. 2003;15(1):17-24. DOI: 10.1207/S15327876MP1501_02

[55] Praslova L. Adaptation of Kirkpatrick's four level model of training criteria to assessment of learning outcomes and program evaluation in higher education. Educational Assessment, Evaluation and Accountability. 2010;22(3):215-225. DOI: 10.1007/s11092-010-9098-7

[56] Alliger GM, Tannenbaum SI, Bennett W, Traver H, Shotland A. A meta-analysis of the relations among training criteria. Personnel Psychology. 1997;50:341-358. DOI: 10.1111/j.17446570.1997.tb00911.x

[57] Arthur W Jr, Bennett W, Edens PS, Bell ST. Effectiveness of training in organizations: A meta-analysis of design and evaluation features. Journal of Applied Psychology. 2003;88(2):234245. DOI: $10.1037 / 0021-9010.88 .2 .234$

[58] Landy FJ, Conte JM. Work in the 21st Century: An Introduction to Industrial and Organizational Psychology. 2nd ed. Malden: Blackwell Publishing; 2007 628p

[59] Landers RN, Callan RC. Training evaluation in virtual worlds:

Development of a model. Journal of
Virtual Worlds Research. 2012;5(3):1-20. DOI: 10.4101/jvwr.v5i3.6335

[60] Gist ME. The influence of training method on self-efficacy and idea generation among managers. Personnel Psychology. 1989;42(4):787-805. DOI: 10.1111/j.1744-6570.1989.tb00675.x

[61] Torkzadeh G, Van Dyke TP. Effects of training on internet self-efficacy and computer user attitudes. Computers in Human Behavior. 2002;18(5):479-494. DOI: 10.1016/S0747-5632(02)00010-9

[62] Combs G, Luthans F. Diversity training: Analysis of the impact of selfefficacy. Human Resource Development Quarterly. 2007;18(1):91-120. DOI: 10.1002/hrdq.1193

[63] Huang WR, Jacobs RL. A comparison of the influences of different training approaches on trainees' perceptions of self-efficacy to achieve training outcomes among bankers in Taiwan. International Journal of Engineering and Industrial Management. 2012;4:35-57

[64] Huang WR, Jao YJ. Comparison of the influences of structured on-thejob training and classroom training approaches on trainees' motivation to learn. Human Resource Development International. 2015;19(2):116-134. DOI: 10.1080/13678868.2015.1096636

[65] Agho AO, Mueller CW, Price JL. Determinants of employee job satisfaction: An empirical test of a causal model. Human Relations. 1993;46:1007-1027. DOI: 10.1177/001872679304600806

[66] Top M, Gider O. Interaction of organizational commitment and job satisfaction of nurses and medical secretaries in Turkey. The International Journal of Human Resource Management. 2013;24(3):667-683. DOI: 10.1080/09585192.2012.680600 
[67] Locke EA. The nature and causes of job satisfaction. In: Dunnette MD, editor. Handbook of Industrial and Organizational Psychology. Vol. 1. 1976. pp. 1297-1343

[68] Hopkins AH. Work and Job Satisfaction in the Public Sector. Rowman \& Allanheld: Totowa; 1983. 146p

[69] Akehurst G, Comeche J, Galindo MA. Job satisfaction and commitment in the entrepreneurial SME. Small Business Economics. 2009;32(3):277-289. DOI: $10.1007 /$ s11187-008-9116-z

[70] Choo S, Bowley C. Using training and development to affect job satisfaction within franchising. Journal of Small Business and Enterprise Development. 2007;14(2):339-352. DOI: $10.1108 / 14626000710746745$

[71] Dormann C, Zapf D. Job satisfaction: A meta-analysis of stabilities. Journal of Organizational Behavior. 2001;22:483-504. DOI: 10.1002/job.98

[72] Judge TA, Heller D, Mount MK. Five-factor model of personality and job satisfaction: A meta-analysis. Journal of Applied Psychology. 2002;87(3):530541. DOI: $10.1037 / 0021-9010.87 .3 .530$

[73] Rowden RW, Conine CT Jr. The impact of workplace learning on job satisfaction in small US commercial banks. Journal of Workplace Learning. 2005;17:215-230. DOI: $10.1108 / 13665620510597176$

[74] Akomolafe MJ, Ogunmakin AQ. Job satisfaction among secondary school teachers: Emotional intelligence, occupational stress and self-efficacy as predictors. Journal of Educational and Social Research. 2014;4(3):487-498. DOI: 10.5901/jesr.2014.v4n3p487

[75] George JM, Jones GR. Understanding and Managing
Organizational Behavior. 6th ed. Harlow: Pearson; 2011. 672 p

[76] Judge TA, Thoresen CJ, Bono JE, Patton GK. The job satisfaction-job performance relationship: A qualitative and quantitative review. Psychological Bulletin. 2001;127:376-407. DOI: 10.1037/0033-2909.127.3.376

[77] Baas M, De Dreu CKW, Nijstad BA. Creative production by angry people peaks early on, decreases over time, and is relatively unstructured. Journal of Experimental Social Psychology. 2011;47(6):11071115. DOI: 10.1016/j.jesp.2011.05.009

[78] Brief AP, Weiss HM. Organizational behavior: Affect in the workplace.

Annual Review of Psychology. 2002;53:279-307. DOI: 10.1146/annurev. psych.53.100901.135156

[79] Isen AM, Baron RA. Positive affect as a factor in organizational behavior. In: Cummings LL, Starr BM, editors. Research in Organizational Behavior. Vol. 13. Greenwich: JAI Press; 1991. pp. 1-53

[80] Hackett RD, Bycio P, Hausdorf PA. Further assessments of Meyer and Allen's (1991) three-component model of organizational commitment. Journal of Applied Psychology. 1994;79(1):1523. DOI: $10.1037 / 0021-9010.79 .1 .15$

[81] Williams LJ, Hazer JT. Antecedents and consequences of satisfaction and commitment in turnover models: A re-analysis using latent variable structural equation methods. Journal of Applied Psychology. 1986;71(2):219231. DOI: $10.1037 / 0021-9010.71 .2 .219$

[82] Konovsky MA, Cropanzano R. Perceived fairness of employee drug testing as a predictor of employee attitudes and job performance. Journal of Applied Psychology. 1991;76:698-707. DOI: 10.1037/0021-9010.76.5.698 
[83] Tella A, Ayeni CO, Popoola SO. Work motivation, job satisfaction, and organisational commitment of library personnel in academic and research Libraries in Oyo State, Nigeria. Library Philosophy and Practice (e-journal). 2007:118. Available from: http://digitalcommons.unl.edu/ libphilprac/118

[84] Awang Z, Ahmad JH. Modelling job satisfaction and work commitment among lecturers: A case of UiTM Kelantan. In: Proceedings of the Regional Conference on Statistical Sciences 2010 (RCSS'10). June 2010. pp. 241-255

[85] Podsakoff PM, MacKenzie SB, Paine JB, Bachrach DG. Organizational citizenship behaviors: A critical review of the theoretical and empirical literature and suggestions for future research. Journal of Management. 2000;26(3):513-563. DOI: $10.1177 / 014920630002600307$

[86] Organ DW. Issues in Organization and Management Series. Organizational Citizenship Behavior: The Good Soldier Syndrome. Lexington Books/D. C. Heath and Com: Lexington; 1988. 132p

[87] Schappe SP. The influence of job satisfaction, organizational commitment, and fairness perceptions on organizational citizenship behavior. The Journal of Psychology. 1998;132(3):277-290. DOI: 10.1080/00223989809599167

[88] Williams LJ, Anderson SE. Job satisfaction and organizational commitment as predictors of organizational citizenship and in-role behaviors. Journal of Management. 1991;17(3):601-617. DOI: $10.1177 / 014920639101700305$

[89] Moorman RH. The influence of cognitive and affective based job satisfaction measures on the relationship between satisfaction and organizational citizenship behavior. Human Relations. 1993;46(6):759-776. DOI: $10.1177 / 001872679304600604$

[90] Bienstock C, DeMoranville C, Smith R. Organizational citizenship behavior and service quality. Journal of Services Marketing. 2003;17(4):357-378. DOI: $10.1108 / 08876040310482775$

[91] Mak BL, Sockel H. A confirmatory factor analysis of IS employee motivation and retention. Information \& Management. 2001;38:265-276

[92] Rust RT, Stewart GL, Miller H, Pielack D. The satisfaction and retention of frontline employees: A customer satisfaction measurement approach. International Journal of Service Industry Management. 1996;7(50):62-80. DOI: $10.1108 / 09564239610149966$

[93] Robbins SP, Judge TA.

Organizational Behavior. 12th ed. Pearson Prentice Hall: Upper Saddle River; 2007. 759 p

[94] Lingard H. The impact of individual and job characteristics on 'burnout' among civil engineers in Australia and the implications for employee turnover. Construction Management and Economics. 2003;21(1):69-80. DOI: 10.1080/0144619032000065126

[95] Karatepe O, Tekinkus M. The effects of work-family conflict, emotional exhaustion, and intrinsic motivation on job outcomes of front-line employees. International Journal of Bank Marketing. 2006;24(3):173-193. DOI: 10.1108/02652320610659021

[96] Jones MK, Jones R, Latreille P, Sloane P. Training, job satisfaction, and workplace performance in Britain: Evidence from WERS 2004. Labour. 2009;23(s1):139-175. DOI: 10.1111/j.1467-9914.2008.00434.x

[97] Vroom VH. Work and Motivation. Oxford: Wiley; 1964. $331 \mathrm{p}$ 
[98] Clegg CW. Psychology of employee lateness, absence, and turnover: A methodological critique and an empirical study. Journal of Applied Psychology. 1983;68(1):88-101. DOI: 10.1037/0021-9010.68.1.88

[99] Drago R, Wooden M. The determinants of labor absence: Economic factors and workgroup norms across countries. ILR Review. 1992;45(4):764-778. DOI: $10.2307 / 2524592$

[100] Mansour JB, Naji A, Leclerc A. The relationship between training satisfaction and the readiness to transfer learning: The mediating role of normative commitment. Sustainability. 2017;9(5):1-14. DOI: 10.3390/su9050834

[101] Schmidt SW. Employee demographics and job training satisfaction: The relationship between dimensions of diversity and satisfaction with job training. Human Resource Development International. 2009;12(3):297-312. DOI: $10.1080 / 13678860902982082$

[102] Siebern-Thomas F. Job quality in European labour markets. In: Bazen S, Lucifora C, Salverda W, editors. Job Quality and Employer Behaviour. London: Palgrave Macmillan; 2005. pp. 31-66

[103] Huang W, Su C. The mediating role of job satisfaction in the relationship between job training satisfaction and turnover intentions. Industrial and Commercial Training. 2016;48(1):42-52. DOI: 10.1108/ICT-04-2015-0029

[104] Memon MA, Ting H, Ramayah T, Chuah F, Cheah JH. A review of the methodological misconceptions and guidelines related to the application of structural equation modeling: A Malaysian scenario. Journal of Applied Structural Equation Modeling. 2017;1(1):i-xiii
[105] Huang WR, Roberge ME, Lan $\mathrm{CH}$. Job training satisfaction and organizational citizenship behavior: The mediating role of organizational commitment and job involvement. 2019. Submitted 



\title{
Maintaining Positive Employee Relations: Does It Apply to Millennials?
}

\author{
Josiane Fahed-Sreih
}

\begin{abstract}
Recruitment, selection, employee appraisal, performance management, compensation, training, and development are all human resource functions that experts are always studying and are considered at the heart of human resource management; however, employees expect more than that. They expect to have a safe work environment, they expect to be treated fairly, and they expect to grow and be recognized in their organizations. Anyone suffering from unfair treatment at work knows how demoralizing this can be and how this can poison trust and reduce employee morale and negatively impact employee relations and performance. When an abusive behavior is observed, this would trigger adverse reactions in addition to further unethical behavior, even if the abusive behavior is hitting a co-worker not the employee himself. When management and employees report a fair treatment, this means that employees are treated with respect and fairly and have demonstrated concrete actions towards fairness and respect. This chapter will highlight the millennials' behavior as related to HR and will identify how the company can keep a positive environment and positive employee relations yet better productivity in the presence of millennials.
\end{abstract}

Keywords: positive employee relations, human resource development, millennials at the workplace, generation Y, motivation, employee attitude

\section{Introduction}

Millennials are also referred to as generation Y. They are born between 1980 and 2000 (or $1979 \& 1994$ ). They represent a sizable population cohort; they are the first generation to have been born into households with computers and to have grown up surrounded by digital media. They are heavy media consumers, creators of personal content on the web, and always described as the "look at me" generation. Needless to say that they are better educated. Since baby boomers are gradually phasing out of the current workforce, millennials are replacing them in order for businesses to continue operating [1,2].

For this reason, it is important to understand the characteristics of this generation as well as what satisfies it on the job and what bothers it. For example, a study conducted on 148 millennials claimed that males are more satisfied on the job than are females, while females are more committed to the organization than males are [3]. Moreover, millennials who proceed to get a graduate degree are found to be more loyal to the company than those who did not earn a graduate degree [2] (Table 1). 


\begin{tabular}{|c|c|c|c|}
\hline $\begin{array}{l}\text { Traditionalists } \\
(1925-1945)\end{array}$ & $\begin{array}{l}\text { Baby boomers } \\
(1946-1964)\end{array}$ & Gen Xers (1965-1980) & Millennials (1981-2000) \\
\hline - Hardworking & • Hardworking & - Entrepreneurial & - Tech savvy \\
\hline - Respectful & - Idealistic & - Flexible & $\begin{array}{l}\text { - Appreciative of } \\
\text { diversity }\end{array}$ \\
\hline - Value loyalty & $\begin{array}{l}\text { - Committed to } \\
\text { harmony }\end{array}$ & - Self-reliant & - Skilled in multitasking \\
\hline $\begin{array}{l}\text { - Conformers who } \\
\text { resist to change }\end{array}$ & $\begin{array}{l}\text { - Self-centered with a } \\
\text { sense of entitlement }\end{array}$ & $\begin{array}{l}\text { - Comfortable with } \\
\text { technology }\end{array}$ & $\begin{array}{l}\text { - Very short attention } \\
\text { spans }\end{array}$ \\
\hline $\begin{array}{l}\text { - Disciplined and } \\
\text { pragmatic }\end{array}$ & -Workaholics & $\bullet$ Lazy & $\begin{array}{l}\text { - Not loyal to } \\
\text { organization }\end{array}$ \\
\hline $\begin{array}{l}\text { - Work and family } \\
\text { lives never coincide }\end{array}$ & - Self-motivated & - Skeptical and cynical & $\begin{array}{l}\text { - Demand immediate } \\
\text { feedback and recognition }\end{array}$ \\
\hline - Dress formally & $\begin{array}{l}\text { - Do not appreciate } \\
\text { feedback } \\
\text { - Dress Formally }\end{array}$ & $\begin{array}{l}\text { - Question authority } \\
\text { figures } \\
\text { - Desire work-life balance } \\
\text { and flexible schedule }\end{array}$ & $\begin{array}{l}\text { - Integrates technology in } \\
\text { the workplace } \\
\text { - Expect to have many } \\
\text { employers and multiple } \\
\text { careers } \\
\text { - Work dress is whatever } \\
\text { feels comfortable } \\
\text { - Lack basic literacy } \\
\text { fundamentals }\end{array}$ \\
\hline
\end{tabular}

Table 1.

Differences between generations (Positive and negative traits).

\section{How are millennials influencing organizations?}

Millennials are influencing the organization with their individualistic traits. They have a positive self-esteem and assertiveness. They also have negative narcissism. For millennials, these increased self-esteem and assertiveness support their belief in the right of individuals to succeed and contribute in the workplace regardless of their background (e.g., the number of years they have spent performing a certain job) and in their right to be treated as an individual entity on the job and not as a part of a larger group. Nevertheless, these characteristics might also be the reason behind their quick exasperation and lack of determination. When independence begins to influence the degree of an individual's narcissistic traits, this could lead the individual to feel entitled, thus fueling their incessant need to gain instant recognition and attention.

Millennials are also risk averse and as such have difficulty dealing with ambiguity and nuance; they often require a clear path to success with clearly defined rubrics and well-defined expectations and constant feedback from their supervisors. According to $[4,5]$, there are several factors that influence millennials on the job, which in turn drive millennials to influence the organization. Such factors could be the social identities of the employees, which affect the organization in different ways depending on the way individuals understand and comprehend these identities $[5,6]$.

Millennials and older generation of workers have differences in values which is affecting millennials' acceptance. When millennials communicate and act according to their backgrounds and values, others' assessments of them may reflect expectancy violations. Only when the new member is deemed valuable to the workgroup and organization do others reciprocate the relationship with commitment. Coworkers begin to ask for the new member's opinions, delegate significant tasks to the new member, and develop meaningful working relationships with the new member. 
Maintaining Positive Employee Relations: Does It Apply to Millennials?

DOI: http://dx.doi.org/10.5772/intechopen. 92798

\begin{tabular}{ll}
\hline Boomers & Millennials \\
\hline $\begin{array}{l}\text { Career is an essential component of their } \\
\text { identities }\end{array}$ & Building a career is not a primary motivator \\
\hline Sacrificed on behalf of the firm & Work is to support the lifestyle they desire \\
\hline Wait their turn for promotion & \\
\hline $\begin{array}{l}\text { Resistance and lack of commitment } \\
\text { perception }\end{array}$ & $\begin{array}{l}\text { Interest in flexible career paths that will allow them to } \\
\text { balance play with work }\end{array}$ \\
\hline
\end{tabular}

Table 2.

Differences between boomers and millennials.

Senior workers' believe that millennial newcomers should have to "pay their dues" as they did when they were young workers.

But boomers are different than millennials; the table shows the difference between those generations (Table 2).

\section{Millennials preference for smaller organizations}

Millennials strongly prefer smaller establishments. Millennials seem to be rejecting the luxury offerings of large establishments, seeing instead the bureaucratic and impersonal environment as unappealing. Regardless of establishment size, co-worker support is a critical part of the work environment for millennials.

\subsection{The relationship of millennials to technology}

According to Pew survey, $75 \%$ of millennials are members of an online social network. $62 \%$ of millennials, more than any other group, connect to the Internet using a laptop or handheld device. 83\% keep their cell phones next to them $24 \mathrm{~h} \mathrm{a}$ day; they are always in touch if they need or want to be.

Millennials' comfort with new media technologies suggests that they bring to the workplace potentially beneficial characteristics related to the use of communication and information technologies (CITs), such as the Web and instant messaging.

Moreover, millennials are of the generation best known for its technological capabilities $[7,8]$. They are able to use several technological devices simultaneously and multitask efficiently. Millennials are also known as the .com generation, which explains why they are so tech savvy and efficient when using technological tools [9].

\subsection{Millennials' bad habits}

Millennials have a tendency to behave in a bad manner in organizations, they always make demands instead of requests, they are over confident, and have a tendency to talk instead of listen, and they prefer the text based communication to the face-to-face communication. They are multitasking, knowing they are always plugged in, and for them assuming a certain behavior or action is always okay.

\subsection{What satisfies the millennials in their job?}

According to one Pew study (2007), 64\% of millennials say that getting rich is the most important goal in life for their generation, and another $17 \%$ cite it as their generation's second most important goal. They actively seek leadership opportunities where they can communicate altruistic values as they become leaders. 
Millennials' parents were extremely concerned with their children's image and also valued their children's opinions as knowledgeable consumers, even involving them in grown-up purchases (from cars to family vacations).

Millennials have high expectations on personal achievement. They expect to find work that is well paying and meaningful, and even to become famous, according to the popular literature.

Millennials do not see money as their only source of happiness. Like generation $\mathrm{X}$ workers, they feel rewarded by work arrangements that offer them more flexibility and new technology. They want to make a difference in the world. If the right job is not available, many are volunteering for organizations such as the Peace Corps or AmeriCorps. Some millennials seem to be satisfied by volunteering or even working in jobs that do not have a high salary or wage, so long that they are able to maintain their living standards, by living with their guardians or parents or by being dependent on their parents to cover for their necessities.

\section{Relationship of millennials to their supervisors}

Millennials view strong relationships with supervisors to be foundational for negotiating their roles initially, as well as for their long-term satisfaction in the organization.

For millennials to achieve higher job satisfaction, an open communication environment is favored.

Millennials would share information, convey bad news, evaluate job performance regularly, create a supportive climate, solicit input, and make appropriate disclosures.

Millennials are unlikely to accept an organizational policy that information is communicated on a "need-to know basis." Millennial employees disagree with their supervisors when it comes to the communication of information. While supervisors might refer to tell employees only the information they feel employees must know in order to complete a task, millennial employees on the other hand prefer to be included in the decision-making process or at least fully informed of how the process occurred. Furthermore, supervisors tend to feel more comfortable discussing information with other supervisors than with their immediate subordinates. In addition, supervisors usually also stress on giving their subordinates instructions that relate to the task without focusing much on the sociological and emotional aspect of communicating the information.

In addition, according to $[10,11]$, challenges might arise in the organization due to differences between generations or cohorts, and differences in the ways these generations prefer to be managed. If these preferences are not given the right amount of attention, they might grow to become large enough to be able to hinder organizational success. Furthermore, one of the leading reasons that drive employees to quit an organization is the poor management of the supervisor or the supervisor's management that is not compatible with the millennial employees [12].

Moreover, Ref. [13] states that supervisors belonging to the baby boomers and generation $\mathrm{X}$ generations need to take into consideration the differences between them and employees belonging to the millennials' generation. Moreover, they should actively attempt to create an environment that fits millennials, challenges them, and motivates them in order to produce the best quality of work and the best results [13]. 


\section{Managing millennials}

The way to manage millennials should be different from managing older generations, for that to succeed, managers should:

1. Make teamwork part of the company structure-Everyone working together with defined roles.

2. Take advantage of their electronic literacy-Experience and knowledge can help expand communication both internally and externally for your firm.

3. Embrace diversity and flexibility-Millennials are willing to stick with companies that have diverse management teams and flexible work environments.

4. Focus on results-Relax the rules to have millennials as hard workers who get results

5. Allow telecommuting or working remotely-To have more success attracting and retaining millennials.

According to [14], millennials are primarily looking for six things on the job from their supervisors. First, they work better with leaders not supervisors. Second, they want to be challenged to do better. Third, they appreciate being able to work in groups. Fourth, they want to enjoy the work they are doing. Fifth, they want to be respected, and finally, sixth, they want to have flexible options [15].

\section{Why are millennials leaving?}

$57 \%$ of millennial workers say it is not very likely or not likely at all that they will stay with their current employers for the remainder of their working life. $62 \%$ of generation $\mathrm{X}$ workers will never leave their current employer. $84 \%$ of baby boomers expect to remain with their current employer for the rest of their working lives.

Based on this information, it is crucial for employers to understand what motivates the millennial generation if they hope to retain these valuable employees.

Baby boomers often advise millennials to persist and be patient-the rewards for their efforts, money, status, and respect will come. However, given the individualistic characteristics of millennials, such as their self-esteem, their sureness, and their self-absorption, together with their aversion towards risk and their incapability of managing vagueness, millennials may not be ready to deal with the reality of the workplace and its severity in certain cases.

The capabilities that enabled generations such as baby boomers to endure and prosper at work, such as being able to negotiate their part, being able to adapt to circumstances that are not ideal, and being able to persist in the face of the uncertain tests which they might encounter, are not the forte of the next generations such as the millennials, which might explain their readiness to leave a job at any time and quit.

Furthermore, Ref. [16] claims that there are different reasons as to why employees leave their job, and these reasons vary based on the country. In the United States, the five most common reasons for a millennial to quit his/her job are negligible pay increases, lack of opportunities to advance, too much overtime required, no room for teamwork, and an inflexible supervisor [16]. 


\section{How to retain millennials?}

Given the costs of turnover, employers have gone to great and costly lengths to attract and retain the millennials. To do so, businesses practices and industry standards must be examined. Giving millennials a bigger paycheck, or even a higher position with an additional increase in pay, may be the key to attract them; however, considering pay is of lesser importance to them with respect to other factors, using it as an incentive might not be sufficient to retain them.

Since having flexible working hours, known as flextime, as well as time for leisure, such as paid vacations or paid days off, are known to be important incentives for millennials, many employers are offering these options in hopes of appealing to millennials and retaining them. Corporate surveys, such as the one conducted by Deloitte in 2009, as well as academic studies, such as the one conducted by [17], show that millennials greatly appreciate having the freedom to complete their tasks in whichever manner they desire, so long as the job is done.

There is no one reason for millennials to leave a job. When millennials perceive a certain unfairness, whether it is because of practices enforced by the employer, or standards brought about at the industry level, or common practices derived from the labor market, they are most likely to regard the situation as unreasonable and unsurmountable, which would cause them to quit. Through such behaviors, millennials seem to be sending a message that they do not accept the norms that were set by the preceding generations, specifically the ones agreed upon by the baby boomers, relating to considering the extended hours of work as a necessity in order to advance in one's career and show commitment to one's organization.

Considering how much millennials value the equilibrium between the time they spend at work and the time they spend doing leisurely activities more than the previous generations did, disturbances that are the result of asymmetrical schedules annoy millennials because they render them unable to control these disruptions or maneuver around them, meaning that the employee will be more likely to indulge in absenteeism or behaviors that are counterproductive. The supervisor or manager will in turn notice this.

Moreover, Ref. [18] claims that knowing or understanding the needs and wants of employees helps in retaining them. He mentions several ways that are effective in order to retain millennials in an organization, such as providing them with more benefits and a flexible schedule, an option to choose, better resources, and opportunities for training and development [19].

\section{How to fix the workplace for millennials?}

\begin{tabular}{lll}
\hline Category & How to handle this & Reason \\
\hline Environment of the work & $\begin{array}{l}\text { Give employees a schedule that } \\
\text { is flexible and a comfortable } \\
\text { workplace. Generate occasions } \\
\text { to interact socially, such as get- } \\
\text { togethers and outdoor activities }\end{array}$ & $\begin{array}{l}\text { Millennials give friendships and } \\
\text { standard of living greater value than } \\
\text { work. They value marriage, children, } \\
\text { and family above work }\end{array}$ \\
\hline $\begin{array}{l}\text { Opportunities to learn } \\
\text { and benefit from training }\end{array}$ & $\begin{array}{l}\text { Reimburse employees on } \\
\text { tuition fees as well as train them }\end{array}$ & $\begin{array}{l}\text { Baby boomer parents brought up their } \\
\text { children to believe that they key to } \\
\text { success is a good education }\end{array}$ \\
\hline Recruitment & $\begin{array}{l}\text { Highlight the methods in which } \\
\text { the organization gives back to } \\
\text { society }\end{array}$ & $\begin{array}{l}\text { A big percentage of millennials claim } \\
\text { that contributing to society is one of } \\
\text { their top priorities }\end{array}$ \\
\hline
\end{tabular}




\begin{tabular}{|c|c|c|}
\hline The onboarding process & $\begin{array}{l}\text { Expose employees to multiple } \\
\text { business units and provide } \\
\text { them with intranet means that } \\
\text { they could pace to their own } \\
\text { comfort to help them establish } \\
\text { relations with other workers }\end{array}$ & $\begin{array}{l}\text { Millennials want connections, } \\
\text { checkpoints, and mentoring }\end{array}$ \\
\hline Ethics concerning work & $\begin{array}{l}\text { Millennials only consider } \\
\text { their job done when they have } \\
\text { tackled it in the best and most } \\
\text { rapid way. This way they can } \\
\text { optimize on their time and } \\
\text { effort }\end{array}$ & $\begin{array}{l}\text { "...when we (Baby Boomers) were } \\
\text { younger, you had a piano teacher who } \\
\text { expected you to practice your piano and } \\
\text { work hard at it, and the parents expected } \\
\text { it. Now, parents say, Have fun, learn the } \\
\text { piano, and practice a little bit," says WSJ } \\
\text { columnist, Jeffrey Zaslow. Millennials } \\
\text { were not brought up to think of the next } \\
\text { step, their main focus was always on the } \\
\text { current task }\end{array}$ \\
\hline Being motivated & $\begin{array}{l}\text { Reward employees with time } \\
\text { off that is considered paid }\end{array}$ & $\begin{array}{l}\text { Millennials view their jobs as "something } \\
\text { to do between the weekends" }\end{array}$ \\
\hline $\begin{array}{l}\text { Relationships with the } \\
\text { upper managers }\end{array}$ & $\begin{array}{l}\text { Win the employee over. } \\
\text { However, be careful while } \\
\text { doing that as the line between } \\
\text { "boss as advocate" and "boss as } \\
\text { friend" is thin }\end{array}$ & $\begin{array}{l}\text { Millennials primarily remain in their } \\
\text { job due to their loyalty towards their } \\
\text { boss or supervisor. However, discontent } \\
\text { with their employer or manager is } \\
\text { also the number one reason why they } \\
\text { leave. Millennials appreciate a close } \\
\text { relationship with a caring supervisor }\end{array}$ \\
\hline Management & $\begin{array}{l}\text { Inform them of the required } \\
\text { results and let them figure out } \\
\text { the means to achieve them. } \\
\text { This might be their chance to } \\
\text { come up with a more efficient } \\
\text { process. To extract their } \\
\text { best performance, link it to } \\
\text { company goals and objectives, } \\
\text { as well as hold them responsible } \\
\text { for their mistakes and } \\
\text { appreciate their achievement. } \\
\text { Imposing on them one way to } \\
\text { do things may drive them to } \\
\text { leave }\end{array}$ & $\begin{array}{l}\text { Millennials were raised and taught } \\
\text { how to solve their problems on their } \\
\text { own, with technology at their side, } \\
\text { linking them to the rest of the world. } \\
\text { For this reason, they do not cope well } \\
\text { when given orders and hate being told } \\
\text { what to do without explanations of the } \\
\text { purpose behind the task. Despite being } \\
\text { impatient, they have a thirst for learning } \\
\text { and acquiring new skills. Millennials } \\
\text { consider themselves able to go with the } \\
\text { best offer on the table. Furthermore, the } \\
\text { support of their parents allows them the } \\
\text { luxury of only choosing what they please } \\
\text { in terms of job acceptance }\end{array}$ \\
\hline Work assignment & $\begin{array}{l}\text { Provide millennials with several } \\
\text { things to do as well as the } \\
\text { potential to interact with the } \\
\text { clients. Furthermore including } \\
\text { them in projects where they } \\
\text { can interact with upper level } \\
\text { employees }\end{array}$ & $\begin{array}{l}\text { They are great multitaskers with } 10 \text { times } \\
\text { the speed and technical knowledge of } \\
\text { their older siblings. Although they have } \\
\text { their own way of thinking, they do like } \\
\text { to work as part of a team. They also value } \\
\text { making an impact and challenging the } \\
\text { norms }\end{array}$ \\
\hline Feedback on performance & $\begin{array}{l}\text { Coaching sessions may be } \\
\text { useful opportunities where } \\
\text { millennials get to discuss their } \\
\text { career paths. Moreover, regular } \\
\text { evaluations and revisions will } \\
\text { also shorten the feedback loop } \\
\text { and provide employees with } \\
\text { performance evaluations }\end{array}$ & $\begin{array}{l}\text { Millennial employees feel that they } \\
\text { earn and deserve a promotion quickly, } \\
\text { and their performance evaluations and } \\
\text { constant feedback reinforce this notion }\end{array}$ \\
\hline Reducing turnover & $\begin{array}{l}\text { Create career paths with a } \\
\text { timeframe short enough for } \\
\text { them to envision. Reward small } \\
\text { successes along the way }\end{array}$ & $\begin{array}{l}\text { They set short-term goals and are } \\
\text { resistant to paying their dues }\end{array}$ \\
\hline
\end{tabular}


It is becoming more and more difficult to satisfy, motivate, and retain millennials in the workplace. In addition to the explained behavior of millennials that is different from boomers, some employees are subject to bullying and victimization, which makes some employees singled out and mistreated. This is a serious problem.

For example, one survey of 1000 employees in the United States concluded that about 455 said that they had worked for abusive bosses. The US government said most would agree that bullying involves three things:

1. Imbalance of power. This includes people who use bullying to control or harm others, while those who are bullied will have a hard time accepting others and defending themselves.

2. The intent to cause harm. Those who are bullying are not doing it accidentally; they intend to harm others.

3. The effect of repetition. Those who engage in bullying intend to harm and hence keep on repeating their behavior over and over again, and this bullying can take many forms:

a. It could be social: Victimizing the person by spreading rumors, trying to leave people out on purpose, trying to break out friendships

b.It could be verbal: Through teasing and name-calling

c. It could be physical: Through hitting, punching, or shoving

d.It could be cyberbullying: Through using the Internet or using mobile phones or other digital technologies to harm others. Through the social media

There are more people who seem to be more harmed by bullying and are more likely to be the victims. Those who are submissive victims are more anxious, cautious, quiet, and sensitive. And there are more proactive victims who show aggressiveness in behavior and others who are victims with low self-determination who leave it to others to make decisions for them. High performers in organizations can create more envious people around them and suffer from victimization. Building teams and creating cohesiveness within the team through training and social gatherings and friendly interteam competition can help reduce the envy and sometimes heal off such envy and reduce victimization.

Beyond fairness, maintaining positive employee relations requires the establishment of communication programs, which would allow management to recognize the problems, allow employees to voice their concerns, and express their opinions and related issues.

Employees always feel better when the organization has communication programs put in place. Many employers though use communication programs to bolster their employee relations efforts. On the assumptions that employees would feel better when they are in the knows, they would appreciate their employers much better when kept in the loop. Encouraging an open door policy and using the webpage and the Internet to keep employees knowledgeable about the company policies and procedures and about the events taking place in the company are all positive to keep employees aware of what is going on. Keeping employees informed boosts the communication programs and improve communication in the company. 
The communication from bottom up is also very healthy in order to keep management knowledgeable about what is happening in the company and what is bothering employees. In order to maintain positive employee relations and in order to short-circuit inequitable treatment, companies are using communication programs such as suggestion boxes to allow employees to voice their opinions, or they host employees to focus groups and get their feedback. They are also connecting to employees via messaging or creating web-based hot lines. Exit interviews are also a way to allow employees to voice their honest opinion while providing another opportunity for employees to sample the quality of their employee relations with their supervisors as well as their peers and to test the internal environment of the organization. Managers might also use, in addition to open doors policies, "management walking around" to informally get employees feedback on how are things going.

Similarly, employers use climate surveys and use attitude and morale surveys to support employee relation efforts. They use the surveys to measure the employees' attitude towards a variety of organizational issues, such as safety, role clarity, leadership, fairness, pay, and whether they can simply improve employee relations. So conducting climate surveys helps management identify the psychological environment, in terms of things like concerns for employee well-being, supervisory behavior, flexibility, appreciation, ethics, empowerment, political behaviors, and rewards.

Many employers use online surveys such as "know your company" survey, in order to get results whether employees are proud to work in their companies, or surveys to assess how satisfied they are with their companies, with their jobs and with their supervisors, and whether the job leads to recognition and respect. Google for instance conducts a "Googlegeist" survey which focuses on the willingness to leave the company.

Providing opportunities for a two-way communication improves employee relations, especially employee recognition and award programs help achieve satisfaction. Knowing that all those survey and programs need planning, $75 \%$ of companies have employee recognition program, and $5 \%$ are planning to have them and to implement them soon. When planning for such programs, one needs to develop the adequate criteria in order to motivate employees to work towards them and in order to have a rational process for actually rewarding employees and awarding recognition awards.

Another way to encourage involvement for millennials in the workplace is to use social media and photo sharing in order to encourage involvement. One survey found that just over half employers use social media tools to communicate with employees and to help develop a sense of community. In addition with millennials, one can use problem-solving teams and quality circles and later engage employees in self-managed teams. Another way to improve employee relations for millennials is to use suggestion systems, which can produce significant savings.

In conclusion, companies should develop well-planned communication programs and can make use of social media in order to engage their millennials in the work place. 


\section{Author details}

Josiane Fahed-Sreih

Department of Management Studies, Institute of Family and Entrepreneurial Business, Lebanese American University, Byblos, Lebanon

*Address all correspondence to: jsreih@lau.edu.lb

\section{IntechOpen}

(c) 2020 The Author(s). Licensee IntechOpen. This chapter is distributed under the terms of the Creative Commons Attribution License (http://creativecommons.org/licenses/ by/3.0), which permits unrestricted use, distribution, and reproduction in any medium, provided the original work is properly cited. $(\mathrm{cc}) \mathrm{BY}$ 


\section{References}

[1] Azalea A, Omar F, Mastor K. The role of individual differences in job satisfaction among Indonesians and Malaysians. European Journal of Social Sciences. 2009;10(4):496-511

[2] Kaifi BA, Nafei WA, Khanfar NM, Kaifi MM. A multigenerational workforce: Managing and understanding millennials. International Journal of Business and Management. 2012;7(24):88

[3] Bott J, Faulk D, Guntupalli A, Devaraj S, Holmes M. An examination of generational differences and media exposure. The Journal of Applied Management and Entrepreneurship. 2011;16(4):78-100

[4] Arsenault PM. Validating generational differences. Leadership and Organization Development Journal. 2004;25(1/2):124-141

[5] Campione WA. The influence of supervisor race, gender, age, and cohort on millennials' job satisfaction. Journal of Business Diversity. 2014;14(1)

[6] Bodenhausen GB. Diversity in the person, diversity in the group: Challenges of identity complexity for social perception and social interaction. European Journal of Social Psychology. 2010;40:1-16

[7] Eastman JK, Iyer R, Liao-Troth S, Williams DF, Griffin M. The role of involvement on millennials' mobile technology behaviors: The moderating impact of status consumption, innovation, and opinion leadership. Journal of Marketing Theory and Practice. 2014;22(4):455-470

[8] Gibson LA, Sodeman WA. Millennials and technology: Addressing the communication gap in education and practice. Organization Development Journal. 2014;32(4):63-75
[9] Farrell L, Hurt AC. Training the millennial generation: Implications for organizational climate. E Journal of Organizational Learning \& Leadership. 2014;12(1)

[10] Alexander KM. Generation Y knowledge workers' experience of work motivation: A grounded theory study [Doctoral dissertation]. Minneapolis, Minnesota: Capella University; 2014

[11] Curtis BJ. Supervisor Behavior: Its Role in the Working Relationship and Retention of Millennial Nurses. 2015

[12] Girard MJ, Lapides J, Roe CM. The Fifth Discipline: A Systems Learning Model for Building High-Performing Learning Organizations. Handbook of Human Performance Technology: Principles, Practices and Potential. 2006. pp. 592-618

[13] Bartz D, Thompson K, Rice P. Maximizing the human capital of millennials through supervisors using performance management. International Journal of Management, Business, and Administration. 2017;20(1):1-9

[14] Raines C. Managing Millennials. Connecting Generations: The Sourcebook, 16. 2002

[15] Gupta P, Goyal P. Gen Y attributesAntecedents to teaching pedagogy. Vision. 2018;22(1):78-87

[16] Goforth A. Why millennials quit their jobs. Benefits Selling. Breaking News. 2015

[17] Twenge JM. A review of the empirical evidence on generational differences in work attitudes. Journal of Business and Psychology. 2010;25(2):201-210

[18] Tulgan B. How to retain millennials. Accounting Today. 2016;30(5):37 
[19] Jayasundera JMA, Jayakody JASK, Jayawardana AKL. Perceived organizational support and turnover intention of Generation Y employees: The role of leader-member exchange. Sri Lankan Journal of Management. 2016;21(2):1-35 


\title{
Contract, Gender, and Job Satisfaction: Evidence from Benin
}

\author{
Monsoï Kenneth Colombiano Kponou
}

\begin{abstract}
This study analyzes the effects of job contract and salary on job satisfaction. Job satisfaction is measured using a subjective approach. As a result, workers themselves have reported their satisfaction levels. The study thus pursues two objectives: (i) to evaluate the effect of the job contract on satisfaction and (ii) to test the existence of a differentiated satisfaction according to gender. Using the data from the School-to-Work Transition Survey (SWTS) database conducted in Benin, we carried out econometric analyses based on the estimation of an ordered probit and a simple probit. Our results confirm the validity of our two hypotheses and also show that nonwage benefits improve worker satisfaction.
\end{abstract}

Keywords: satisfaction, employment, employment contract, gender, ordered probit

JEL codes: J28, J31, J44, J81

\section{Introduction}

Job quality is increasingly analyzed in the economic literature and is closely linked to that of job satisfaction. This question goes beyond the neoclassical model in which wages are the only variable that gives satisfaction to the worker. In other words, the economic agent participates in the labor market because the salary provides utility and the latter increases as the salary increases. Indeed, several studies have shown that a worker's satisfaction does not depend only on his salary [1-5]. These authors have shown, for example, that nonmonetary factors such as holidays with pay, vocational training, and union membership are also factors that contribute to the job quality and thus may influence the worker's level of satisfaction. Several measurement approaches are used to analyze job quality. Basically, these methods can be classified into two groups. The first group offers a subjective analysis where workers are made evaluators of their job quality levels. This method uses the levels of satisfaction that workers report as an indicator of job quality. It is therefore possible to directly analyze workers' responses to questions about the degree of importance given to safety, wages, personal fulfillment, or work schedules [6]. The second group relies on the use of data to construct job quality indices [7-9]. This approach is described as objective in the literature.

Work is a particular good that has attributes that provide different benefits to the worker. These attributes are the type of work contract, hours of work, salary, and extra-salary benefits. A standard employment relationship is governed by contract. But in the context of developing countries where the informal sector is an important part of economic activities, the employment contract is often nonexistent 
most of the time. And yet, the majority of benefits and job arrangements are governed by the employment contract. It is therefore of great importance in job satisfaction. Job satisfaction can vary significantly according to some characteristics of the worker such as sex. By the way, several studies have concluded that women are generally more satisfied than men [10-13]. For Lévy-Garboua et al. [14], satisfaction expresses an experienced preference of current employment against available job alternatives. Clark [15] suggests that women in general have fewer requirements than men, which explains their higher level of job satisfaction.

This study takes a labor analysis approach that goes beyond the neoclassical framework because it is based on the assumption that only salary does not provide satisfaction. In this sense, this study examines the effect of the employment contract on job satisfaction on the one hand and the effect of gender on job satisfaction on the other hand. The rest of the study is organized in four sections. The second section presents the review of the literature, the third presents the methodology, the fourth presents the results and the discussions, and the last concludes the study.

\section{Literature review}

We summarize the literature with emphasis on three important aspects: (i) the role of nonwage aspects in the labor supply, (ii) the relationship between work contract and satisfaction, and (iii) the link between heterogeneity of preferences and job satisfaction.

\subsection{Beyond the neoclassical model}

The salary is no longer the only element of satisfaction of the worker. The unemployed say they are less happy than the workers, but this difference in satisfaction is not only explainable by wages. Beyond wages, there are other attributes that provide usefulness and satisfaction to workers.

\subsubsection{The Kunze and Suppa labor supply model: the role of nonwage aspects}

The model begins with the Lancaster Demand Features approach [16]. The idea of Lancaster [17] is that it is not the goods that produce utility to the consumer but the characteristics that the goods possess (see, e.g., the works of [18]). The good can have more than one characteristic, and the same characteristics can be obtained from more than one good. It is assumed that the characteristics are objective and measurable, for example, a meal provides (i) a certain amount of calorie, (ii) a nutritional composition, and (iii) esthetic characteristics. The technical relationship that transforms goods into their characteristics is called consumer technology. Utility or preference is supposed to classify characteristics, while all goods are only classified indirectly using the characteristics they possess. Formally, Lancaster's consumer program is as follows:

$$
\begin{gathered}
\text { Max } U(\mathrm{z}) \\
\mathrm{z} \\
\text { subject to }: \mathrm{px} \leq \mathrm{k} \\
\text { with }: \mathrm{z}=\Phi \mathrm{x} \\
\mathrm{z}, \mathrm{x} \geq 0
\end{gathered}
$$


where $\mathrm{U}(\mathrm{z})$ is a standard neoclassical utility function defined in the feature space (C-space). The budget constraint $\mathrm{px} \leq \mathrm{k}$ is defined on the property space (G-space). The system of equations $\mathrm{z}=\Phi \mathrm{x}$ represents the transformation between C-space and G-space where the matrix $\Phi$ describes the consumption technology of the economy. Consumer choices can be either studied in the space of goods (as in traditional analysis) or in the space of the characteristics of goods.

To construct a model that analyzes the relationship between the characteristics of a job and the number of hours of work chosen by the individual, we consider $\mathrm{N}+1$ goods, that is to say $\mathrm{x}=(\mathrm{L} 1, \mathrm{~L} 2, \ldots, \mathrm{Ln}, \ldots ., \mathrm{LN}, \mathrm{C}) . \mathrm{C}$ represents the consumption of good, and each of the other $\mathrm{N}$ goods, Ln, represents a specific amount of time used in the consumption of these respective goods. As a result, each $\mathrm{Ln}$ is called activity in the following, and the total amount of time used for these activities is normalized to unity. It is further assumed that each activity provides $\mathrm{K}$ characteristics, while the consumption of good has a single characteristic. Consumption technology $\Phi$ is a format matrix $(K+1)^{*}(N+1)$. The labor supply produces any of the $\mathrm{K}$ activity-related characteristics, but none of these produces the characteristics of consumption. Consequently, each element of the matrix $\Phi$, denoted $\varphi \mathrm{kn} \geq 0$, determines the quantity of characteristics $\mathrm{k}$ provided by the use of a unit of time for the activity $\mathrm{n}$. There are therefore several activities that provide different combinations of features. The approach developed here is based on two activities: the work activity providing a remuneration, a certain amount of selected characteristics; and a residual activity possibly including leisure, volunteering that produce the same selected quantity of characteristics. From the perspective of an empirical analysis of the couple's labor supply, we interpret $C$ as the consumption of the family in the following, and we denote L1, L2, and (1-L1) and (1-L2) as the times of each spouse in the work activity and in the residual activity. The vector $\mathrm{x}$ can be written as follows:

$$
\mathbf{x}=\left(\mathrm{L}_{1}, 1-\mathrm{L}_{1}, \mathrm{~L}_{2}, 1-\mathrm{L}_{2}, \mathrm{C}\right)
$$

By limiting the theoretical analysis to a characteristic of work by spouse and normalizing some coefficients to the unit, the consumption technology $\Phi$ is finally of the following form:

$$
\left(\begin{array}{ccccc}
\varphi_{1} & 1 & 0 & 0 & 0 \\
0 & 0 & \varphi_{2} & 1 & 0 \\
0 & 0 & 0 & 0 & 1
\end{array}\right)
$$

The parameters $\varphi_{-} i(i=1,2)$ measure the productivity of the work with respect to the residual activity. Since (1-L1) is the combination of several distinct activities, we assume that $\varphi \mathrm{i}<1(\mathrm{i}=1,2)$. This indicates that there is at least one activity that is more productive to achieve this characteristic. Using Eq. (3), the second constraint of Eq. (1) can be finally written as follows:

$$
z=\Phi X^{\prime}=\left(\begin{array}{c}
\varphi_{1} L_{1}+\left(1-L_{1}\right) \\
\varphi_{2} L_{2}+\left(1-L_{2}\right) \\
C
\end{array}\right)
$$

We start from a Cobb-Douglas utility function. Here is the problem:

$$
U(z)=\alpha_{1} \ln \left(z_{1}\right)+\alpha_{2} \ln \left(z_{2}\right)+\left(1-\alpha_{1}-\alpha_{2}\right) \ln \left(z_{3}\right)
$$

subject to $C=w_{1} L_{1}+w_{2} L_{2}+R_{1}+R_{2}$

$z=\Phi X^{\prime}$ 
where $\mathrm{x}$ and $\Phi$ are not given the previous equations. $\mathrm{Ri}(\mathrm{i}=1,2)$ is the nonwage exogenous income of the individual. This income alone is not important, but what is it is the sum $R=R 1+R 2$. The utility function is increasing in $\varphi_{i}(i=1,2)$ which means that $U_{\varphi_{\mathrm{i}}} 0$. The implication is that an improvement in quality translates into an increase in the utility level of the individual. Solving the problem gives:

$$
L_{i}^{*}=\frac{1-\alpha_{i}}{1-\varphi_{i}}-\frac{\alpha_{i}}{w_{i}}\left\{\frac{w_{j}}{1-\varphi_{j}}+R\right\}
$$

with $i=1,2 ; j=1,2$ et $i \neq j$.

Note that the labor supply function $L_{i}^{*}$ is decreasing with respect to the level of nonwage income $\mathrm{R}$ and also in relation to the income level of spouse $w_{j}$. On the other hand, this function is increasing with respect to the level of income $\varphi_{i}$ of the individual and in relation to the level of quality of work. The main implication of this discrete choice model is that it shows the importance of the nonpecuniary aspects of employment. This is because the elasticities of the labor supply are significantly different, given the characteristics of the work. This model can then be used as a basis to show that the worker's satisfaction goes beyond the only salary aspect.

\subsection{Hours, contract, and job satisfaction}

There are several studies in the empirical literature that show that work hours have a negative effect on the job satisfaction level $[12,13,15]$. These studies, after controlling for work income bias, obtain negative effect of working hours on the job satisfaction level. This result can be explained by the fact that the work is in fact a disutility and that it is desired only for the benefits it provides. Dawson and Veliziotis [19] found that fixed-term workers report a lower level of subjective well-being than workers with indeterminate employment contracts. The explanation of these authors is that workers who have permanent work contracts have their state of well-being decreased mainly through their increased feeling of insecurity at work.

This result is in line with that found by Zanden [20]. The idea is that the longer people work in a job, the more they feel more secure and therefore postpone a higher level of well-being. It is in this sense that Chadi and Hetschko [21] examined the role of flexicurity with a view to compensating for job security for workers with temporary employment contracts. Green and Heywood [22] showed that while part-time work is an important negative determinant of job satisfaction from a safety at work perspective, it can be a positive contributor to other dimensions of job satisfaction. In a study of developing countries, Bóo et al. [23] showed that women's job satisfaction level is not related to the partial nature of employment. On the other hand, their results indicate that part-time jobs have a negative effect on the level of job satisfaction of men. This indicates that men have a stronger preference for permanent jobs compared to women.

\subsection{Heterogeneity of preferences and job satisfaction}

Women have jobs that are, in general, less attractive than those available to men. Better still, women are less empowered and more supervised and have little access to career development opportunities relative to men [24, 25]. However, women have a better attitude and appreciation of their jobs than men [12, 13, 26]. According to Hodson [10], there are two possible explanations for this paradox. 
The first is that women do not evaluate the same aspects of employment. The second is that women see themselves more in the role of housework rather than worker. This means that when they work outside the home, they feel extra satisfaction. According to Clark [15], the difference in job satisfaction is due to the fact that women generally have fewer requirements than men and therefore may have to postpone a higher level of satisfaction than men.

\section{Methodology}

This study uses data from the School-to-Work Transition Survey (SWTS) database. The survey collected data on the Beninese labor market, focusing on the age group 15-29 in 2012. The survey is representative of the target population at the national level.

\subsection{Models of job satisfaction}

This study adopted two measures of job satisfaction. The first is the level of overall job satisfaction reported by the workers themselves, and the second is the satisfaction of the same workers in relation to their employment contract.

\subsubsection{Equation of the overall level of job satisfaction}

The job satisfaction variable is multinomial and has four modalities. These terms range from "very dissatisfied" to "very satisfied" to "somewhat dissatisfied" and "somewhat satisfied." A level of satisfaction reported can be considered as the achievement of a certain random variable having a probability distribution. In this sense, we can model the level of satisfaction as Kifle and Kler [27] did:

$$
\mathrm{y} *=\mathrm{x} \beta+\mu
$$

where $\mathrm{y}^{*}$ is a latent variable indicating the unobservable level of job satisfaction. $\mathrm{X}$ is a matrix of sociodemographic variables, $\beta$ a parameter vector, and $\mu$ the error term. This equation cannot be estimated unless we have a categorical variable whose terms are ordered randomly. Let y be this categorical variable with a set of threshold points $\mathrm{Zi}$. The conditional probability of any observation can be expressed as follows:

$$
\begin{aligned}
\operatorname{Pr}(\mathrm{y}=\mathrm{i} / \mathrm{x}) & =\operatorname{Pr}(\mathrm{Zi}-1 \leq \mathrm{x} \beta<\mathrm{Zi}) \\
& =\operatorname{Pr}(\mathrm{Zi}-1 \leq \mathrm{y} *+\mu<\mathrm{Zi})
\end{aligned}
$$

where $\mathrm{i}$ is in this case the level of job satisfaction reported on a scale of 1-4:

$$
\begin{aligned}
\operatorname{Pr}(\mathrm{y} & =\mathrm{i} / \mathrm{x})=\operatorname{Pr}(\mathrm{Zi}-1-\mathrm{x} \beta \leq \mu<\mathrm{Zi}-\mathrm{x} \beta) \\
& =\operatorname{Pr}(\mu<\mathrm{Zi}-\mathrm{x} \beta)-\operatorname{Pr}(\mu \leq \mathrm{Zi}-1-\mathrm{x} \beta) \\
& =\Phi(\mu<\mathrm{Zi}-\mathrm{x} \beta)-\Phi(\mu \leq \mathrm{Zi}-1-\mathrm{x} \beta)
\end{aligned}
$$

where $\Phi($.$) is the standard cumulative distribution function.$

The probability that an employee will choose a level of satisfaction i given the explanatory variables $(\mathrm{x})$ is the difference between the cumulative distribution function of the normal law evaluated at the point of $\mathrm{i}(\mathrm{Zi})$ minus the vector of 
explanatory variables multiplied by their respective coefficients and the cumulative distribution function of the normal law evaluated in the previous point ( $\mathrm{Zi}-1)$ minus all the explanatory variables multiplied by their respective coefficients.

It will therefore be estimated as the following equation:

$$
y i=x i \beta+\mu_{i}
$$

The appropriate estimation technique to the estimation of Eq. (10) is the ordered probit, given the categorical and orderly nature of these modalities.

\subsubsection{Equation of satisfaction with the employment contract}

The satisfaction variable with respect to the employment contract provides information on the state of satisfaction of the work in relation to his employment contract. It is obvious that in labor markets in developing countries such as Benin, the issue of employment contract is of particular importance, particularly because of the high prevalence of informal sector activities, sector known for its lack of regulation and therefore its lack of respect for the labor code. It appears that in this context, the use of job satisfaction is a relevant measure of job satisfaction. But one could think to remain in a so-called objective process and systematically consider a worker having no employment contract as dissatisfied or less satisfied compared to another who has a contract. But the reality is that it is not always obvious that someone with a part-time contract has less well-being than someone with a fulltime contract. Instead of remaining in such an approach and defining criteria of external satisfaction to the worker, we prefer the approach that makes the worker his own evaluator of his level of satisfaction. The variable we use for this purpose seems relevant to us since it takes 1 when the worker declares to be satisfied with respect to his employment contract and 0 otherwise.

The equation of worker satisfaction with respect to his employment contract can be estimated by the probit method given the dichotomous nature of the satisfaction variable. An equation will therefore be estimated of the following general form:

$$
\mathrm{Si}=\operatorname{Bi} \Sigma+\varepsilon \mathrm{i}
$$

where $\mathrm{Si}$ is the satisfaction status with respect to the employment contract, $\mathrm{Bi}$ is the matrix of the explanatory variables, and $\varepsilon i$ is the error term.

\section{Results and discussions}

Table 1 presents the ordered probit estimation results of Eq. (10), while the second model presents the probit results of Eq. (11). These two estimates take satisfaction in employment as explained variable. The goal of two regressions is to test the robustness of our results.

Table 1 presents the estimation results of two equations, which are variable in explaining the level of job satisfaction. The difference between the two equations lies in the measurement of the type of work contract. Indeed, in the first estimate, we measured the contract type by the contract type variable. This variable is dichotomous and takes 1 when the worker is under an undetermined contract (CDI) and 0 if under a fixed-term contract (CDD). In the second equation, the type of work contract was measured by the variable duration of the contract which is multinomial with three modalities. The first category takes into account contracts with a duration of less than 12 months, the second category takes into account 
Contract, Gender, and Job Satisfaction: Evidence from Benin

DOI: http://dx.doi.org/10.5772/intechopen.90358

(1)

(2)

\begin{tabular}{|c|c|c|}
\hline Variables & Job satisfaction & Job satisfaction \\
\hline Age & $\begin{array}{l}-0.058^{*} \\
(0.031)\end{array}$ & $\begin{array}{c}-0.141^{* * *} \\
(0.048)\end{array}$ \\
\hline Sex (reference: woman) & $\begin{array}{l}-0.266 \\
(0.262)\end{array}$ & $\begin{array}{l}-0.163 \\
(0.424)\end{array}$ \\
\hline Marital status (married or not) & $\begin{array}{c}0.343 \\
(0.223)\end{array}$ & $\begin{array}{c}0.132 \\
(0.368)\end{array}$ \\
\hline Want to change job & $\begin{array}{c}-1.237^{* * *} \\
(0.244)\end{array}$ & $\begin{array}{c}-2.131^{* * *} \\
(0.318)\end{array}$ \\
\hline Type of contract (full time or part time) & $\begin{array}{l}0.378^{*} \\
(0.207)\end{array}$ & - \\
\hline \multicolumn{3}{|c|}{ Contract duration (reference: less than 12 months) } \\
\hline 12-36 months & - & $\begin{array}{c}0.785^{*} \\
(0.406)\end{array}$ \\
\hline 36 months and more & - & $\begin{array}{l}0.772^{* *} \\
(0.368)\end{array}$ \\
\hline \multicolumn{3}{|l|}{ Financial status (reference: difficult) } \\
\hline Rather difficult & $\begin{array}{l}0.766^{* * *} \\
(0.293)\end{array}$ & $\begin{array}{l}1.030^{* *} \\
(0.402)\end{array}$ \\
\hline In the national average & $\begin{array}{l}1.133^{* * *} \\
(0.307)\end{array}$ & $\begin{array}{l}1.259^{* * *} \\
(0.420)\end{array}$ \\
\hline Rather easy & $\begin{array}{l}1.258^{* *} \\
(0.532)\end{array}$ & $\begin{array}{l}3.134^{* * *} \\
(0.969)\end{array}$ \\
\hline Easy & $\begin{array}{c}2.483^{* * *} \\
(0.827)\end{array}$ & $\begin{array}{l}8.676^{* * *} \\
(0.688)\end{array}$ \\
\hline \multicolumn{3}{|l|}{ Education (reference: no level) } \\
\hline Primary & $\begin{array}{c}-0.919^{* * *} \\
(0.305)\end{array}$ & $\begin{array}{c}-2.252^{* * *} \\
(0.528)\end{array}$ \\
\hline Vocational & $\begin{array}{l}-0.658 \\
(0.409)\end{array}$ & $\begin{array}{l}-0.875 \\
(0.708)\end{array}$ \\
\hline Secondary & $\begin{array}{l}-0.331 \\
(0.294)\end{array}$ & $\begin{array}{c}-1.754^{* * *} \\
(0.547)\end{array}$ \\
\hline Higher vocational & $\begin{array}{c}-1.241^{* * *} \\
(0.427)\end{array}$ & $\begin{array}{c}-2.871^{* * *} \\
(0.670)\end{array}$ \\
\hline University & $\begin{array}{c}-1.116^{* * *} \\
(0.375)\end{array}$ & $\begin{array}{l}-1.801^{* * *} \\
(0.628)\end{array}$ \\
\hline Postgraduate & $\begin{array}{c}-0.970^{* *} \\
(0.428)\end{array}$ & $\begin{array}{l}-2.599^{* * *} \\
(0.738)\end{array}$ \\
\hline \multicolumn{3}{|c|}{ Discrimination (reference: more chances for men) } \\
\hline Equal opportunities & $\begin{array}{l}0.508^{* *} \\
(0.252)\end{array}$ & $\begin{array}{c}1.049^{* * *} \\
(0.399)\end{array}$ \\
\hline More chances for women & $\begin{array}{l}-0.103 \\
(0.355)\end{array}$ & $\begin{array}{l}-0.864 \\
(0.558)\end{array}$ \\
\hline Want to work more & $\begin{array}{c}0.207 \\
(0.237)\end{array}$ & - \\
\hline Observations $^{1}$ & 379 & 179 \\
\hline $\begin{array}{l}\text { Source: Estimate from the SWTS database. } \\
{ }^{1} \text { The number of observations has risen to } 179 \text { bec } \\
\text { not include in the second estimate the variable } w\end{array}$ & tration variable $w$ & ll number. As a r \\
\hline
\end{tabular}

Table 1.

Determinants of the level of job satisfaction. 
contracts from 12 to 36 months, and the last modality contracts longer than 36 months. Despite this difference, the two equations produced the same results.

\subsection{Age and job satisfaction}

It appears that age has a negative effect on job satisfaction. This means that as the worker gets older, he feels less and less satisfied at work. If we use age as a proxy for work experience, this result means that the most experienced workers are less and less satisfied. We tested the nonlinear relationship assumption, but the results indicate that there is no effect of age on the level of satisfaction. This result could be surprising but can still be explained.

The first explanation is that the data we use is collected on a sample of young workers only. The age range is from 15 to 29 years old. This may not be able to bring out the good effect of age since in this age group, workers are often still far from retirement age or have not yet had enough experience in the profession to assess all facets of their expectations vis-à-vis employment. A second explanation is that as mentioned by Franěk and Večeřa [28], older workers may feel disappointed. Their expectations become limited and experience increases the pressure by factors such as technological developments and adaptations in the work. Clark et al. [29] found that the relationship between age and job satisfaction can be synthesized by a Ushaped curve. Our result does not follow the same direction as [29] but does not contradict it either. Indeed, a U-shaped relationship means that the level of satisfaction drops with age first and then increases. This is the first negative effect we obtained in this study because Clark et al.'s [29] study focused on workers aged 15-60 years and older.

\subsection{Work contract and job satisfaction}

The permanent employment contract is associated with a higher level of satisfaction compared to the fixed-term contract. This result seems obvious in the sense that a part-time worker is less satisfied than a full-time worker. This difference is mainly due to the job security that the worker feels and that is increased in the case of permanent work contracts. Our result is in line with what is generally found in the literature. For example, Green and Heywood [22], Chadi and Hetschko [21], and Zanden [20] have all shown that there is a significant difference between the satisfaction levels of part-time and full-time workers and that, in addition, a parttime contract is a factor that lowers the level of job satisfaction. The contract of employment as a document defining the essentials of labor relations is the one that gives a status to the work. It helps to make him feel a job security. This has the effect of impacting his level of well-being at work. But in a labor market where the rate of informality is high, not all workers are necessarily entitled to the formal employment contract.

We obtain the same effect when we consider the results of Eq. (2) where the type of contract of employment was measured in duration. Thus, we note that compared to the contract of less than 12 months, the other longer terms of contract are associated with higher levels of satisfaction. It can then be stated that not only is the type of work contract a determinant of the level of satisfaction, but also that workers on short-term contracts are less satisfied than those on long-term contracts.

\subsection{Education and job satisfaction}

Overall, it appears that compared to workers who have no level of education, other workers report a lower level of satisfaction. This result is explained by the fact 
that as the level of education increases, the worker has more and more high expectations of employment. By combining this state of affairs with the age group of our study (15-29 years), we can easily understand the effect obtained. By taking the example of an individual with a university level, it is obvious that he enters the labor market at an age that is such that around 29 years old, he is still very little experienced. It is established that early-career workers expect a lot from employment, which leads them to postpone low satisfaction levels. Our results do not agree with those of Pisani [30] who finds that a high level of education is associated with a better state of job satisfaction. According to Bender and Heywood [31] who analyzed the satisfaction of high-skilled workers by gender, women are more satisfied than men in nonacademic occupations.

\subsection{Perceived discrimination and job satisfaction}

The analysis of discrimination was introduced in economics by Becker [32]. It consists of treating differently two people with identical productive characteristics but having a different observable nonproductive characteristic. Becker considers that some employers, colleagues, or customers have a particular taste for discrimination. As a result, members of the discriminated group receive a lower salary to compensate for this inconvenience. Arrow [33] and Phelps [34] developed statistical discrimination as an alternative to Becker's vision. It is based on beliefs. If the employee belongs to the employer's group, the latter knows its true productivity. If the employee belongs to the discriminated group, which the employer does not know, the latter thinks that he is on average less productive than his own group and then pays him according to this average and not according to his real productivity. We see that the effect of the discrimination passes through another factor which may be the salary, career development possibilities, etc. In this study, we examine the effect of discrimination perceived by the worker on his level of job satisfaction. Our results in this regard indicate that when the level of job satisfaction is high, then workers perceive an absence of discrimination, that is, equal opportunities for men and women. This result is also that obtained by Madera et al. [35]. Indeed, these authors have shown that perceived discrimination is related to a low level of satisfaction and a greater desire for job rotation at the worker level.

\subsection{Financial situation, salary, and job satisfaction}

The neoclassical theory of the labor market establishes that salary is the only variable that determines the level of job satisfaction. In this sense, there is a positive relationship between salary levels and satisfaction. Given the availability of statistics, we used the financial status variable rather than the salary variable. This choice is justified by two reasons. The first is that we assume that the wage is closely related to the worker's financial situation. The second is that the study borrows approach of subjective evaluation. Thus, the financial situation variable used is an evaluation made by the workers themselves. As a result, it seems to us to be a relevant variable in our analysis.

The results indicate that in both equations, as the worker has a better perception of his financial situation, he feels more satisfied at work. In the empirical literature, the relationship between salary level and satisfaction is often studied. But even if the determinants of wages are well known, the effect of wages on the level of job satisfaction is less known. According to results obtained by Judge et al. [36], the wage level is positively correlated with the level of job satisfaction. This is in line with the effect we have achieved. On the other hand, authors such as Young et al. [37] found that the increase in wages has a negative effect on the level of worker 
satisfaction. The explanation of these authors is that wages evolve with experience. Thus, the more the worker becomes experienced and gains better and better, he sets even more new goals. Thus, his quest to always reach higher wage levels is an explanation that bases such a salary effect on satisfaction.

\subsection{Desire to change jobs and job satisfaction}

The variable desire to change jobs as an explanatory variable could possibly be the basis of a possible endogeneity bias if the unobservable factors that determine this desire are the same ones that base the state of satisfaction. But estimating models with and without this variable produced the same overall results. We note that the desire to change jobs has a negative influence on job satisfaction. It is obvious that when a worker wants to change jobs, either he is not satisfied with his current job or he has a better opportunity. In both cases, this leads to a low level of job satisfaction (Table 2).

\subsection{Gender and satisfaction with the contract}

In contrast to the result obtained with regard to job satisfaction, it is clear here that sex has a significant influence on job satisfaction. Indeed, we note that women are more satisfied with the employment contract than men. Empirical work often shows that women are more satisfied than men in most aspects of job satisfaction. Kifle and Desta [11] showed, for example, that men are more satisfied with hours of work and career opportunities, while women are more satisfied with relationships with their colleagues and with their contribution to the society. In order to test the validity of the effect we obtained and to test its robustness, we proceeded to tests of comparison of proportions according to the sex on the two measures of satisfaction which we adopted. To do this, we recoded the global satisfaction variable. Thus, we considered all those who reported satisfaction levels 1 and 2 as satisfied and who were satisfied with those who reported levels 3 and 4 . This allowed us to have a binary variable just like the other variable with the satisfaction with the contract to

\begin{tabular}{lcc}
\hline Variables & Coefficients & Margins \\
\hline Age & 0.019 & 0.005 \\
& $(0.029)$ & $(0.008)$ \\
\hline Sex & $0.494^{* *}$ & $0.143^{* *}$ \\
& $(0.244)$ & $(0.069)$ \\
\hline Marital status & -0.283 & -0.082 \\
& $(0.243)$ & $(0.069)$ \\
\hline Paid vacation & $0.760^{* * *}$ & $0.22^{* * *}$ \\
& $(0.276)$ & $(0.077)$ \\
\hline Insurance (reference: do not know) & & \\
\hline Unlikely & 0.244 & 0.083 \\
& $(0.603)$ & $(0.199)$ \\
\hline Probable but not certain & $1.007^{*}$ & $0.357^{*}$ \\
& $(0.583)$ & $(0.19)$ \\
\hline Very probable & $1.575^{* * *}$ & $0.518^{* * *}$ \\
& $(0.603)$ & $(0.191)$ \\
\hline Observations & 394 & 394 \\
\hline
\end{tabular}

Table 2.

Gender and employment contract satisfaction. 
test sex ratio comparisons. The results indicate that, in general, women report being more satisfied than men. This result is in line with what is often found in the empirical literature.

\subsection{Extra-salary benefits and satisfaction with the employment contract}

Nonwage benefits are an important part of workers' evaluation of their jobs. The Kunze and Suppa [16] model has helped to show the importance of nonwage aspects in the labor supply and more generally in the decision to participate in the labor market. Our results indicate that workers have access to these kinds of benefits and they are satisfied. This is a result that is easily understood.

\subsection{Job retention insurance and satisfaction with the contract}

A worker who does not have the assurance of keeping his job is in a situation of insecurity. Such a situation must have a consequence on his level of satisfaction. In examining the effect of such a variable, we have noticed that as the worker is assured of keeping his job, he is satisfied with his employment contract. And better, the results indicate that the effect is gradually increasing until the worker reaches the point where he has the certainty of keeping his job.

\section{Conclusion}

This paper examined the effects of work contract and gender on job satisfaction in Benin. Satisfaction was measured using two variables: overall satisfaction level and satisfaction with the work contract. The effects were obtained by estimating two models. The results indicate that the level of job satisfaction is sensitive to the type of contract. This result was obtained by evaluating the work contract by its type (permanent contract or fixed-term contract) and by its duration. In both cases, the results indicate the same effect. Thus, workers with a long-term work contract are associated with high levels of satisfaction. In terms of satisfaction with the employment contract, it appears that the job retention insurance improves the level of satisfaction of the worker. In terms of gender, we noted a lack of difference in effect in estimating the equation of the overall level of satisfaction. But there is a difference of effect when one considers the satisfaction with the contract of employment. This difference is favorable to women. In other words, women are more satisfied with their employment contracts compared to men. This effect has been confirmed by a set of proportional comparison tests that go in the same direction. In addition to these results, we also found that nonwage benefits improve worker satisfaction. 


\section{Author details}

Monsoï Kenneth Colombiano Kponou

Faculty of Economics and Management of University of Abomey-Calavi, Benin

*Address all correspondence to: drkenneth@yahoo.com

\section{IntechOpen}

(C) 2020 The Author(s). Licensee IntechOpen. This chapter is distributed under the terms of the Creative Commons Attribution License (http://creativecommons.org/licenses/ by/3.0), which permits unrestricted use, distribution, and reproduction in any medium, provided the original work is properly cited. (c) BY 


\section{References}

[1] Clark A. What makes a good job? Job quality and job satisfaction. In: IZA World of Labor; 2015. pp. 1-10. DOI: 10.15185/izawol.215

[2] Davoine L. Les Déterminants de la Satisfaction au Travail en Europe: L'importance du Contexte (No. 76). Paris, France: CEE; 2006

[3] Davoine L. La Qualite de L'emploi: Une Perspective Europeenne. Université Paris I Panthéon-Sorbonne; 2007

[4] Pouliakas K, Theodossiou I. SocioEconomic Differences in the Perceived Quality of High and Low-Paid Jobs in Europe. 2005

[5] Standing G. From people's security surveys to a decent work index. International Labour Review. 2002; 141(4):441-454. DOI: 10.1111/ j.1564-913X.2002.tb00248.x

[6] Clark AE. What Makes a Good Job? Evidence from OECD Countries. In: Bazen S, Lucifora C, Salverda W, editors. Job Quality and Employer Behaviour. London: Palgrave Macmillan; 2005

[7] Bonnet F, Figueiredo JB, Standing G. Une famille d'indicateurs du travail décent. Revue Internationale du Travail. 2003;142(2):231-260. DOI: 10.1111/ j.1564-913X.2003.tb00118.x

[8] Crespo N, Simoes N, Pinto JC. Determinants Factors of Job Quality in Europe. 2013

[9] Huneeus F, Landerretche O, Puentes E. Determinants of Job Quality: Persistence and Dynamic Segmentation in the Labor Market of a Developing Country2012. pp. 1-48

[10] Hodson R. Gender difference in job satisfaction: Why aren't women more dissatisfied? The Sociological Quarterly. 1989;30(3):385-399
[11] Kifle T, Desta IH. Gender differences in domains of job satisfaction: Evidence from doctoral graduates from Australian universities. Economic Analysis and Policy. 2012; 42(3):319-338

[12] Sousa-Poza A, Sousa-Poza AA. Job Satisfaction and Labor Turnover: Does Gender Matter? (No. 94)2003. pp. 18-21

[13] Sousa-Poza A, Souza-Poza AA. Gender differences in job satisfaction in Great Britain, 1991-2000: Permanent or transitory? Applied Economics Letters. 2003;10(11):691-694

[14] Lévy-Garboua L, Montmarquette C, Simonnet V. Job Satisfaction and Quits: Theory and Evidence from the German Socioeconomic Panel. 2001

[15] Clark AE. Job satisfaction and gender: Why are women so happy at work? Labour Economics. 1997;4(4): 341-372

[16] Kunze L, Suppa N. Job

Characteristics and Labour Supply. Ruhr Economic Paper No. 418. June 32013. Available from: https://ssrn.com/ abstract=2278872 or http://dx.doi.org/ $10.2139 /$ ssrn.2278872

[17] Lancaster KJ. A new approach to consumer. The Journal of Political Economy. 1966;74(2):132-157

[18] Rustichini A, Siconolfi P. Preferences over characteristics and utility functions over commodities. Economic Theory. 2008;36(1):159-164. DOI: $10.1007 / \mathrm{s} 00199-007-0258-\mathrm{z}$

[19] Dawson C, Veliziotis M. Temporary Employment, Job Satisfaction and Subjective Well-Being (No. 1309)2013. pp. 1-28

[20] van der Zanden R. The Impact of Employment Contract on Workers' 
Well-being: A Cross-National Study on the Impact of Flexibilization of the Labor Market. Radboud University Nijmegen; 2014

[21] Chadi A, Hetschko C. Flexibilisation Without Hesitation? Temporary Contracts and Workers (No. 04). 2013

[22] Green CP, Heywood JS. Flexible contracts and subjective well-being. Economic Inquiry. 2011;44:716-729

[23] Bóo FL, Madrigal L, Pagés C. PartTime Work, Gender and Job Satisfaction: Evidence from a Developing Country (No. 3994). 2009

[24] Berch B. The Endless Day: The Political Economy of Women and Work. New York: Harcourt Brace Jovanovich; 1982

[25] Wolf WC, Fligstein ND. Sex and Authority in the Workplace: The Causes of Sexual Inequality (No. 78-16). 1979

[26] Penley LE, Hawkins BL. Organizational communication. performance, and job satisfaction as a function of ethnicity and sex. Journal of Vocational Behavior. 1980;16(3): 368-384

[27] Kifle T, Kler P. Job Satisfaction and Gender: Evidence from Australia. 2006

[28] Franěk M, Večeřa J. Personal characteristics and job satisfaction. Ekonomie a Management. 2008;11(4): 63-76

[29] Clark A, Oswald A, Warr P. Is job satisfaction U-shaped in age? Journal of Occupational and Organizational Psychology. 1996:57-81

[30] Pisani K. Education as Related to Job Satisfaction and Health. Stockholm University; 2009

[31] Bender K, Heywood S. Job satisfaction of the highly educated:
The role of gender, academic tenure, and comparison income. Scottish Journal of Political Economy. 2006; 02(05):253-279

[32] Becker G. The Economic of Discrimination. The University of Chicago Press Economics; 1957

[33] Arrow K. What has economics to say about racial discrimination? Journal of Economic Perspectives. 1973;12(2): 99-100

[34] Phelps E. The statistical theory of racism and sexism. American Economic Review. 1972;62(4):659-661

[35] Madera JM, King EB, Hebl MR. bringing social identity to work: The influence of manifestation and suppression on perceived discrimination, job satisfaction, and turnover intentions. Cultural Diversity and Ethnic Minority Psychology. 2012; 18(2):165-170. DOI: $10.1037 / \mathrm{a} 0027724$

[36] Judge TA, Piccolo RF, Podsakoff NP, Shaw JC, Rich BL. The relationship between pay and job satisfaction: A meta-analysis of the literature Timothy. Journal of Vocational Behavior. 2010;77(2): 157-167. DOI: 10.1016/j.jvb.2010.04.002

[37] Young L, Milner M, Edmunds D, Pentsil G, Broman M. The tenuous relationship between salary and satisfaction. Journal of Behavioral Studies in Business. 2014;7:1-9 


\title{
Go Back to the Beginning: Career Development and the Challenges of Transitioning from the Military to Civilian Employment
}

\author{
Mirsad Bahtic, Verma Prikshat, John Burgess \\ and Alan Nankervis
}

\begin{abstract}
This chapter examines the transition challenges facing military personnel to moving to civilian employment, a major issue for nations like the USA that have large armed forces. For such personnel, they seek to establish a career after a period of service and often without the credentials required for existing or future job vacancies. This chapter discusses the challenges of career transition from military to civilian employment, largely in the context of the US-based literature. The chapter proceeds to outline the range of obstacles to transition and then considers remedial measures to support transition ranging from pre transition to post transition support programs.
\end{abstract}

Keywords: transitional labour markets, career shift, transferable skills, military employment, civilian employment, career disruption

\section{Introduction}

Career development is not a linear and continuous process. Many workers face challenges and disruptions to their careers linked to the nature of their work (for example, seasonal work); the disruption caused by health, disability and caring for children and relatives; and the short duration of many careers that require a change (for example in professional sports). Whilst the general concept of a 'career' is currently undergoing significant change due to the implementation of new disruptive technologies and the emergence of a global 'gig' economy, it can be effectively captured in all its variations as 'the sequence of jobs that individuals hold during their work histories regardless of their occupations or organisational levels' [1]. The literature is conflicted about whether organisations or individual employees have the key responsibilities for career management and career development [2]. Disrupted and career re-development is extensive in the workforce. Mass layoffs associated with plant closures, technological change and global competitive pressures force many workers to search for jobs in new regions or industries, or to retrain for new occupations. Typical transitional challenges are from graduation to work [3], and from full time caring to work. The concept of transitional labour 
markets $[4,5]$ captures the adjustment process of moving from one position to another where the shifts involve challenges and access linked to securing job entry and sustaining a career.

The transition from military to civilian life is a challenging one, impacting personal growth, life satisfaction, psychological well-being, and the physical health of many veterans after their deployment [6]. Many veterans struggle with managing their psychological health, and as such, returning to work can be difficult as mental health symptoms can influence individuals' abilities to gain or maintain employment [7]. Some research suggests a correlation between employment status and various mental health conditions, including post-traumatic stress disorder (PTSD), anxiety disorder, depression, alcohol and drug abuse [8]. While many successfully transition from military services into civilian employment, there remain a residual of ex-military employees that find accessing the civilian labour market difficult. In this chapter the obstacles and challenges to civilian employment are identified, rather than those who have successfully transitioned into civilian employment.

Military personnel returning to civilian life face an array of psychological, physical and social challenges that are not typically addressed during their service periods [9]. The Australian Senate Inquiry into the mental health of defence personnel [10] found that one of the key issues contributing to military personnel stress and anxiety was the difficulty of accessing a civilian job, with claims that the unemployment rate for veterans was around five times the national average, at 30\% [11]. In combination with mental and physical disabilities, unemployment contributes to a vicious circle of social exclusion for veterans. Disabilities and other factors contribute to difficulties in accessing jobs, including employer stereotyping of ex-defence personnel [12], and in turn being unable to secure employment contributes to their stress. In this context, it is important that the relationship between military service and post-service access to suitable employment is evaluated, as the concerns facing ex-defence personnel are complex, and impact a multitude of different areas in civilian life (health care, employment, disability), and therefore they require more specialist case-management services [13].

This chapter discusses these transitional challenges from military to civilian employment, largely based on United States studies. Specific transitional challenges including health, skills recognition and employer stereotyping are identified. Then follows a discussion of the processes and programs that can potentially support the transition and the establishment of a civilian career.

\section{What are the challenges associated with transition from military to civilian employment?}

The processes and experiences of transition for veterans to civilian life and employment are not well understood, and it is often a transition with concomitant challenges related to identity, employment, and lifestyle $[14,15]$. Veterans, especially those who have had extended periods of service or lack experience in job search processes, can experience numerous challenges when seeking post-service employment [16], and may create unrealistic expectations regarding salary and job search time-frames. Some veterans experience financial struggles, while others have relationship problems and/or substance abuse issues. When compounded with the challenges associated with securing post-military employment, these can lead to less overall stability upon return to civilian life [17].

The transition process is also often viewed as being difficult due to associated learning or relearning to live outside the highly organised, regimented and controlled way of life experienced during military service. Many veterans may have 
begun their military careers immediately following high school, so another challenge in this transition process is gaining civilian employment for the first time and becoming familiar with the associated practices of job search [16]. They will need to seek employment in non-military fields and transferring their status can prove stressful [18]. They are not only leaving the military as a job, but also as a way of life. This can also lead to a higher rate of mental health disorders $[13,19]$, as there is a mismatch between veterans' expectations and reality. Many veterans will feel they are returning to a "normal" way of life, but in reality, due to the nature of military service and the emotional and physical scars veterans endure during their deployment, they can often feel isolated or alienated upon return to civilian life [20]. As such, the nature of the transition is far more complex psychologically than often recognised, and this needs to be considered when discussing the transition process [18]. Potential employer stereotyping that veterans are too regimented, inflexible, and unable to adapt to civilian work situations [21] further exacerbate their employment-seeking challenges.

Another reason why many veterans struggle to readjust to civilian life is in part due to the socioeconomic and educational challenges they may have experienced prior to individual military service [22], for example, entering military service without possessing any formal post school qualifications and because of the decline in direct supervision in post-military life. Many individuals do not have plans for employment post-military service; and may also lack a sustainable plan for living arrangements upon completion of their service given that accommodation is usually provided by the military, thus potentially leading to poverty and homelessness. Military establishments are often located in remote regions, placing a physical and financial barrier to accessing jobs in large urban areas with expensive property markets. In addition research suggests that some veterans have experienced challenges with anger upon returning to civilian life, strained family relationships, and post-traumatic stress disorder (PTSD). If not treated, these issues can lead to poor coping strategies that can result in an increase in substance abuse and which may have originated during active duty. According to the US Department of Defence Health Related Behavior Survey, $84.5 \%$ of active duty personnel across all military branches reported using alcohol and $25 \%$ reported moderate to heavy substance use, which is significantly higher than in non-military civilians (16.6\%) [23].

\section{The challenges of transition from military to civilian employment in the USA}

The Pentagon has reported that around 1.6 million military personnel who returned from the Afghanistan war in late 2001 struggled to find employment $[24,25]$. US soldiers aged between 22 and 24 years old were three times more likely to be unemployed when compared with non-US soldiers in the same age bracket [25]. Due to the young age of enlistment by military personnel, many do not have college degrees when they join the military, thus making it even more difficult to find employment post-service. For example, in 2008, the year with the highest deployment of US military overseas, $52 \%$ of military personnel were 25 years old or younger, and only $4.5 \%$ had a bachelor's degree [26].

Due to the hazardous and life-threatening nature associated with military employment, returning veterans may suffer either physical and/or psychological challenges, as indicated by the increasing rate of disability claims [27]. Many US veterans are also at risk of severe life-threatening issues, with data indicating that, in 2014 around 20 veterans committed suicide every day [28]. While some knowledge and skills possessed by military personnel are transferrable to the civilian workplace 
(for example, administrative, computer and problem-solving skills), an inability to illustrate how these skills are transferrable is one of the primary reasons for veterans' unemployment. In addition, the current population is more educated today than ever before, and this has led to veterans having to face a more competitive marketplace when seeking employment [29].

In the following sections we briefly outline some of the key institutional and structural challenges that contribute to the veteran's post service career access in civilian employment.

\subsection{Mental health and substance abuses}

Several studies have examined veterans' employment outcomes when confronted with a primary diagnosis of post-traumatic stress disorder (PTSD), although primarily in the United States. Savoca and Rosenheck's study [30], for example, found that Vietnam-era veterans with combat-related PTSD were significantly less likely to be employed than those without PTSD, and a PTSD diagnosis was also associated with a lower hourly wage for those in a civilian job. Increased severity of PTSD was associated with a decreased likelihood of fulltime employment in another cross-section study of veterans with PTSD [31]. Resnick and Rosenheck's study [32] observed that veterans with PTSD were 19\% less likely to be employed on discharge.

Unaddressed associated mental health and substance abuse issues manifest themselves in several ways in relation to civilian employment [33]. Army veterans with health challenges (physical and psychological) may face employment concerns especially in finding and maintaining work [34]. Moreover, in some cases, the psychological effects of deployment tend to limit veterans' ability to work, and they are often hesitant to seek assistance, feeling that documented mental health issues may limit their employment options [35]. Further, due to negative pre-conceived notions of self-stigmas associated around their health, it becomes difficult for them to participate in employment preparation and screening processes [36]. Finally, physical and psychological concerns can affect veterans' access to education and training, thus further reducing the chances of employment [36].

\subsection{Skills transferability challenges}

The skills transferability of army veterans, in terms of equating military skills and experiences with civilian job qualifications, is reported as one of the most significant employment-related challenges [37]. For successful civilian employment army veterans are required to re-interpret the skills developed in their military jobs (e.g. planning, leadership, risk mitigation, decision-making, communicating, and military intelligence capabilities), and to articulate them effectively in the civilian employment marketplace [38]. The US Society of Human Resource Management (SHRM), Prudential, the RAND Corporation, the Center for New American Security (CNAS), and Pew Research, have all identified these gaps in translating military skills to post- military service careers as either the number one or number two issue in effective military career transition and career development [21].

\subsection{Negative employer perceptions}

Although many employment programs acknowledge the various skills gained by veterans during their army careers, there is disparity among employers regarding recognition of these skills [39]. As an example, a study by Harrell and Berglass [37] identified leadership and teamwork skills, character, discipline, expertise, resilience 
and loyalty to be some of the reasons for hiring the veterans. However, the same study reported that skill transferability, negative stereotyping, skills mismatches, repeated deployments, and acclimatisation to the civilian world were listed as risks and challenges for hiring veterans. It is also noted in the literature that many employers perceive veterans as either a mismatch for civilian employment, and further, employers often considered veterans as being unsuited to civilian employment [40]. According to Castro et al. [40], post-9/11 veterans reported that civilian employers did not understand their needs, did not think military veterans have the necessary skills, considered veterans to be dangerous and physically broken, and did not want to hire them.

Employers were found to often hold false stereotypical perspectives about army veterans, their skills and experiences, and their estimated "employability" based on political ideology, assumptions of poor skills or presumptions of mental or emotional dysfunction [40]. There is a reported lack of research in understanding the difficulties experienced by employers and veterans regarding suitable positions in civilian environments and workplaces [37]. Moreover, given the employment problems experienced by veterans and many employers' unwillingness to recruit them, few research studies have examined the factors that affect such hiring decisions [39].

\subsection{Unpreparedness for civilian employment}

Much extant literature has observed that the lack of preparation and understanding for finding civilian employment when leaving the military is a large contributor to veteran unemployment [40]. It has been observed that some veterans have unrealistic expectations of their civilian job prospects, and some employers are hesitant to hire them due to their poor interviewing skills and inadequate resumes [41]. This unpreparedness has been linked to limited initiative, lack of appropriate planning and lack of motivation, as observed by Keeling, Kintzle and Castro [42] - 'The tools are there, the motivation is not' (p. 67). In some cases, even the transition services provided by the military authorities either did not prepare them for what to expect from civilian life or are ineffective in providing opportunities for employment [40].

\subsection{Role of military identity and cultural adjustment}

Military identity and values (for example, duty, honour, loyalty; and commitment to comrades, unit, and nation) conflict with materialistic, individualistic and libertarian civilian values, which can create a 'civil-military cultural gap'. These identity crises impact upon their chances of finding suitable employment, as veterans often maintain a continuity of "military identity" due to "military institutionalisation" which may adversely affect their transition to civilian life [43]. This further suggests that due to this institutionalisation, the skills many civilians are accustomed to using (the ability to conduct job searches or tailor communication methods) are under-developed in veterans [44]. Previous literature also indicates that to maintain their military identity, veterans tend to seek work within other "masculinised" and military like institutions (for example, prisons and security work) or prefer to travel around in order to relive the experience of temporary postings in the military [44]. Preconceived notions of differences in civilian and military organisational cultures may also be related to hiring decisions about veterans for civilian jobs [39].

Somewhat related to the role of military identity and the presence of a 'civilmilitary cultural gap', veterans may face cultural adjustment issues in civilian jobs. Previous research reports on challenges faced by army veterans suggest that 
transitioning veterans experience a "culture shock" when re-entering civilian life [15], and the major reason for this is related to the army culture of selfless service [45]. The career transition involves moving away from not being in charge or making decisions (or being the subordinate) and requires changes in mindsets, adapting, and in what may influence persistence, effort, interest, and career goals [46]. Employers expect that veterans must bring the ability to demonstrate adaptive performance, employability, adaptability, functionalism, and flexibility - often capabilities they do not possess.

It has been observed that military service can decrease civilian wages, and the longer the duration in the military, the greater the wage differential faced by veterans relative to civilians [47]. Finding acceptance in a new organisation can be a challenge for veterans to adapt to a career change and a new kind of organisation. There are suggestions that the realities of the military-to-civilian career transition may become fraught with adversities, frustrations, inequities, and setbacks in the workplace with supervisors or co-workers.

\subsection{Educational attainment challenges}

Complementing academic knowledge with veterans' skills developed in the military through educational attainment is one effective way of making a transition from army service to civilian employment [48]. Previous research has linked educational attainment to employment mobility [49]. However, veterans face additional challenges that make it difficult for them to succeed in higher education - for example, understanding what benefits they are eligible for, finding campus administrators who understand government support/assistance complexities, obtaining academic credit for military training, and finding services on campus that support their integration into civilian student life [50]. Moreover, veterans as students are different from traditional students and may be raising families and maintaining full-time employment or part-time enrollment, which may result in a higher risk for course non-completions $[49,50]$. Another challenge is the difficulty in meeting academic expectations (for example, balancing work and family while studying; independent study and analysis; relating to fellow students; meeting lecturers' expectations) that are significantly different from what veterans have encountered in military courses [50].

Further, for educational attainment, it is important for the veterans to seek academic credit for coursework and training received in the military. This poses a strong challenge for educational institutions, as military transcripts in the US context consist of indecipherable acronyms - the "military alphabet", rattling off a list of numbered and lettered forms and courses-and some are even officially classified - so the knowledge or participation could not be acknowledged or certified [48]. Difficulties lie in maintaining consistencies in credit transfers [50,51] and determining whether given credit applies to unit requirements, general education or graduation requirements, or major and major preparation requirements [51].

\subsection{Physical disability}

While most studies of the difficulties facing veterans in the transition to civilian employment have highlighted mental disability, many veterans also face physical disability. Serving in the defence forces, especially on active duty, involves facing potential life-threatening risks on a daily basis. Veterans who suffer physical disability are able to access rehabilitation, counselling and welfare support services during and post service. However, many disabilities are permanent or have associated effects such as pain, disability and limited attention spans [52]. There is also 
an interaction between physical and mental stress [52]. Having a permanent injury may contribute to anxiety and impacts on the ability to engage in effective job search activities [48]. As with mental disability, there are also many documented barriers to those with physical disabilities in accessing employment and workplaces [53].

\subsection{Job search challenges}

In the case of job search for ex-service personnel there are a number of distinct challenges. The first is spatial, that is being removed from locations where there are jobs. Job search requires access and resources. Many military establishments are located outside capital cities, often in remote regions, and this imposes physical and financial barriers to effective job search. In addition, military personnel often have limited networks that support job access. Many nations, including the US, Australia, UK and New Zealand, have special services and outplacement arrangements for ex service personnel [54]. There are several job search support services available for Australian ex-military personnel to support job search - these include The Career Transition Access Scheme (CTAS) [55] and the Veterans' Employment Program [56]. Linked to physical separation are the associated costs and disruption of physical relocation. This may involve new schools for children; job search for spouses; and accessing accommodation in expensive capital cities. For those ex-servicepersons with families the challenges and disruption are collective; the transition to civilian life presents problems for the entire family, often moving from a military town dominated by the military, and moving to multi-cultural and cosmopolitan cities with diverse populations, industries and networks [48].

\section{Strategies for overcoming the challenges of transition and developing a civilian career}

Where there are barriers to career transition and to developing a new career, addressing the challenges requires informed, flexible and complementary remedial measures. In the case of the transition from university and college graduation to a career position, there a range of stakeholders who have an interest in ameliorating the identified problems that prevents transition. These include students/graduates; employers; universities and governments [3] since there are large private and public investments in education that a predicated on the ability to transition from graduation to employment and generate private and public returns from the investment [3]. Responses range from better informed course and institutional selection; education programs that incorporate required job skills; improving job search processes; public funding of university programs on the basis of successful job placements; and providing articulation arrangements, such as traineeships [3].

In the military transition context the challenges are more profound than in the case of the education transition. Veterans are seeking to transition from one career to a different career; they often have few formal qualifications; they have not been preparing for the transition and in many cases they have personal attributes such as health problems that further limit their employability. In terms of the barriers, policy responses have to encompass the multitude of challenges discussed above, and the different market and non-market sources of these challenges [48-51]. The articulation of 'process' and the holistic approach to resilience, acculturation and identity also allows us a deeper understanding of the different assistance programs countries have in place to address these challenges. In the UK, the Ministry of Defence formulated a Strategy for Veterans and Armed Forces Covenant [54]. In the USA, Congress established a Transition Assistance Program (TAP) [56]. 
The transition experiences of veterans are often complex, and a successful transition requires a portfolio of supports and programs, encompassing action from many stakeholders, including the military, government, employer groups, non-government organisations such as veteran's associations, education and training institutions to address potential risks and protective factors [57]. As with education to employment transitions, the remedial process is not homogeneous in terms of the personal characteristics of those transitioning (education, skills, age, years of service, disability, location) [3], and requires co-ordination across many authorities and stakeholder groups. The following table (Table 1) shows the different challenges and some of the potential strategies that have been outlined in the literature, along with the intervention time-frame (before, during or after transition).

The strategies included in the table include the US transition assistance programs (TAP) which support veterans by providing pre-separation counselling and transition assistance workshops to aid in the transition from military service to civilian life; career assessments (regarding career interests, self-efficacy, and career resilience); and in Australia, the 'Career Transition Assistance Scheme - CTAS which provides phased benefits, tools and services in support of this obligation [55]. The CTAS [55] supports the career transition of members from the service to suitable civilian employment, with the minimum involuntary break in continuity of employment; enhances the ability of members to competitively market themselves for suitable civilian employment; and attempts to make the best use of members' existing skills gained from ADF service.

In response to the transition challenges identified in the above discussion, there are six key complementary imperatives which might be provided by human

\begin{tabular}{|c|c|c|c|}
\hline & Challenges & Potential strategies & Time phase \\
\hline 1 & $\begin{array}{l}\text { Mental health and } \\
\text { substance abuse }\end{array}$ & Counselling and social support & $\begin{array}{l}\text { During transition } \\
\text { and afterwards }\end{array}$ \\
\hline 2 & Skills transferability & $\begin{array}{l}\text { Certification for skills; preparation for civilian } \\
\text { employment }\end{array}$ & On-going \\
\hline 3 & Employers' perceptions & $\begin{array}{l}\text { Educate HR professionals and employer } \\
\text { associations }\end{array}$ & On-going \\
\hline 4 & $\begin{array}{l}\text { Preparation for civilian } \\
\text { employment }\end{array}$ & Transition Assistance Programs (TAP) & $\begin{array}{l}\text { Before and during } \\
\text { transition }\end{array}$ \\
\hline 5 & $\begin{array}{l}\text { Military identity and } \\
\text { cultural adjustment }\end{array}$ & Realignment and adaption of new behaviours & $\begin{array}{l}\text { Training workshops } \\
\text { during transition and } \\
\text { afterwards }\end{array}$ \\
\hline 6 & Acceptance challenges & Industry orientation workshops & $\begin{array}{l}\text { Training workshops } \\
\text { before and during } \\
\text { transition }\end{array}$ \\
\hline 7 & $\begin{array}{l}\text { Educational } \\
\text { enhancement }\end{array}$ & $\begin{array}{l}\text { Recognition of prior leaning/training to higher } \\
\text { education community/education assistance } \\
\text { programs } \\
\text { Formal accreditation procedures for training } \\
\text { programs. }\end{array}$ & On-going \\
\hline 8 & $\begin{array}{l}\text { Physical disability } \\
\text { challenges }\end{array}$ & $\begin{array}{l}\text { Reserved positions for disabled veterans in } \\
\text { federal jobs }\end{array}$ & On-going \\
\hline 9 & Job search challenges & Job search support programs & Ongoing \\
\hline
\end{tabular}

Table 1.

Identified transition challenges and potential responses. 
resource management (HRM) professionals for the mutual benefit of veterans and their organisations. First, in order to overcome the stereotyped beliefs and self-adopted stigmas of veterans [36, 39], one important strategy is to alter these preconceived notions of employers [39]. Human resource professionals might take the lead in providing career development, learning and development, and hiring support to create a better understanding about veterans in the civilian workplace [15]. They need to consciously understand the application of military frameworks to current business practices and develop an understanding how the skills of veterans can be utilised to create a more viable, innovative, creative, and leadershipready workforce [58]. Moreover, recruiters need tools and associated training to help them understand the benefits of hiring veterans [59].

HRM professionals can assist veteran recruits to transition to new civilian work identities by addressing the three phases that every individual making a transition encounters: (a) letting go of old ways and old identities, (b) moving out of a "neutral zone" and experiencing psychological realignment, and (c) exiting the transition and beginning anew with a new identity and sense of purpose. HRM professionals can design strategies to support veterans in their psychological realignment and establish a new identity with a clear sense of purpose $[48,50]$.

Through recognition of prior learning (RPL) mechanisms, veterans might be given academic credit for coursework and training received in the army [49]. The nature of military expertise and the knowledge accumulated while in service may have different connotations in course curriculum. Although some veterans have completed academic qualifications and applied training during their military service, some educational institutions do not award credit for military training [49]. Bergman and Herd [60], for example, strongly advocated assisting veterans with academic credit for prior learning in the military and recommended a program of portfolio development for prior learning assessment (PLA) method provided by the Council for Adult and Experiential Learning [CAEL] in 2010. Veterans tend to be of mature age, and consequently their success often depends on their ability to make rapid progress and build on the knowledge they have established in the services. Establishing consistent credit transfer guidelines and transparency about those guidelines can go a long way to help veterans attain education for smoothly transitioning into civilian employment.

As many higher education providers do not understand military cultures or the challenges veterans face when transitioning to an academic setting [61], it is imperative that higher education personnel develop awareness of the complex and multiple identities of students so that they can introduce effective programming initiatives [49]. Providing training to faculty and staff about military culture and veterans' unique needs and transitional issues [62] can help improve the situation. These initiatives could be complemented with educational assistance programs that can prevent the unemployment of veterans, assist their adjustment to civilian life, reward their military service, and make education affordable [63]). The GI Bill (US Education and Training Benefit), for example, provides monetary aid to help cover college tuition, housing, books, and other educational fees for vocational training, on-the-job training, flight training, correspondence training, licencing, national testing programs, entrepreneurship training, and tutorial assistance [63].

Finally, and most controversially, in the US veterans are given preferences in appointments to federal government jobs [64]. Public policies in the US have also attempted to boost the demand for veteran labour through federal hiring preferences and private employer tax credits [63]). Veterans who are disabled or who serve on active duty in the US Armed Forces during certain specified time periods or in military campaigns are also entitled to preference over non-veterans both in federal hiring practices and in retention during reductions in force [63]. 


\section{Conclusion}

The concept of a single career with linear and sequential development, and long periods of tenure with a single employer has been disrupted by technological and structural changes that undermine the marketability of skills, qualifications and experience [1]. Career development is for many a disrupted process, involving transition challenges and shifts in career orientation, and often involving structural and institutional barriers [5]. Moving out of military to civilian employment captures many of the structural, institutional and market barriers that those who seek to change careers face, but as indicated the challenges and the barriers to the transition process are systemic and considerable [40]. This chapter reports on the challenges faced by army veterans in their transitions into civilian employment, largely in the US context. The main challenges that have been highlighted in extant research are based around mental health and substance abuse; skills transferability; negative employer perceptions towards veterans; the lack of preparation for entry into the civilian workforce; the negative military identity (and stereo-typing); the cultural challenge of civilian employment; insufficient educational attainment; physical disability; and job search challenges [29-34]. The challenges are not homogenous and require tailored support programs to assist veterans. These may range from job search and training programs; through to rehabilitation programs to assist those with physical and mental health challenges. There is need for multiple stakeholder responses that include support for transition while in military service; and support from a range of stakeholders across the range of identified impediments from NGOs, through to governments and employer groups in the post transition phase. Developing a career is challenging when you enter the civilian workforce at an age where existing participants have civilian employment experience and recognised skills and credentials.

Further research could examine the differences in the transitional challenges across countries and across different defence services such as the navy and air force. Here contextual factors such as the conditions and forms of service in different countries, and the skills required to perform different service tasks could affect the ability to transition to civilian employment. Moreover, studies that examine successful transition can identify those conditions that contribute to supporting the transition and career development process.

\section{Author details}

Mirsad Bahtic ${ }^{1}$, Verma Prikshat ${ }^{2}$, John Burgess ${ }^{3 *}$ and Alan Nankervis ${ }^{1}$

1 Curtin University, Perth, Australia

2 Cardiff Metropolitan University, Cardiff, United Kingdom

3 RMIT University, Melbourne, Australia

*Address all correspondence to: john.burgess@rmit.edu.au

\section{IntechOpen}

(C) 2020 The Author(s). Licensee IntechOpen. This chapter is distributed under the terms of the Creative Commons Attribution License (http://creativecommons.org/licenses/ by/3.0), which permits unrestricted use, distribution, and reproduction in any medium, provided the original work is properly cited. (cc) BY 


\section{References}

[1] Nankervis A, Baird M, Coffey J, Shields J. Human Resource Management: Strategy and Practice. 10th ed. Melbourne: Cengage; 2019

[2] Mercer. Mercer Talent Trends 2017: Empowerment in a Disrupted World. London: Mercer; 2017

[3] Cameron R, Dhakal S, Burgess J. Transitions from Education to Work: Workforce Ready Challenges in the Asia Pacific. Abingdon: Routledge; 2018

[4] Schmid G. Transitional Labour Markets: A New European Employment Strategy Discussion Paper FS I 98 -206. Berlin: Wissenschaftszentrum Berlin für Sozialforschung; 1998

[5] Schmid G. Social risk management through transitional labour markets. Socio-Economic Review. 2006;4(1):1-33

[6] Roberts PE. Post-9/11 veterans: Welcoming them home as colleagues and clients. The University of Memphis Law Review. 2015;45(4):771

[7] Harrod M, Miller E, Henry J, Zivin K. I've never been able to stay in a job: A qualitative study of veterans' experiences of maintaining employment. Work. 2017;57(2):259-268

[8] Hawthorne G, Korn S, Creamer M. Australian Peacekeepers: Long-Term Mental Health Status, Health Service Use, and Quality of Life - Summary Report. Melbourne, Vic: University of Melbourne; 2014

[9] Cassidy JM. Suddenly discharged the combat continues: Eliminating the legal services gap to ensure veterans' success after leaving military service. The University of Memphis Law Review. 2015;45(4):837. Xx

[10] Commonwealth of Australia. The Constant Battle: Suicide by Veterans.
Canberra, ACT: Senate Foreign Affairs, Defence and Trade Reference Committee; 2017

[11] Lavoipierre A. Unemployment Major Contributor to Veteran Suicide Rates, Senate Inquiry Hears. 2017. Retrieved from: https://www.abc.net. $\mathrm{au} /$ news/2017-02-02/unemploymentlinked-to-veteran-suicide/8235240

[12] Coady D. Veterans Struggling with Unemployment Urge Employers to Look Beyond Misconceptions. 2017. Retrieved from: https://www.abc. net.au/news/2017-10-05/veteransunemployment-rates-higher-thannational-average-report/9017554

[13] Kukla M, Rattray N, Salyers M. Mixed methods study examining work reintegration experiences from perspectives of veterans with mental health disorders. Journal of Rehabilitation Research and Development. 2015;52(4):477-490

[14] Ford DG. Talent management and its relationship to successful veteran transition into the civilian workplace: Practical integration strategies for the HRD professional. Advances in Developing Human Resources. 2017;19(1):36-53

[15] Minnis SE. A Phenomenological Exploration of Combat Veterans' Experiences as they Transition to Civilian Employment Using Higher Education as Career Development. College Station: Texas A\&M University; 2014

[16] Soergel A. Paving the Way from Warrior to Worker. 2015. Retrieved from: https://www.usnews.com/news/ articles/2015/11/02/closing-the-jobsgap-initiatives-aim-to-pave-way-forveteran-transition

[17] U.S. Government Accountability Office Report. Transitioning Veterans 
Improved Oversight Needed to Enhance Implementation of Transition Assistance Program. 2014. Retrieved from: https:// www.gao.gov/assets/670/661361.pdf

[18] Jones KC. Understanding student veterans in transition. The Qualitative Report. 2013;18(74):1-14

[19] Maiocco G, Smith MJ. The experience of women veterans coming back from war. Archives of Psychiatric Nursing. 2016;30(3):393-399

[20] Ahern J, Worthern M, Masters J, Lippman S, Ozer E, Moos R. The challenges of Afghanistan and Iraq veterans' transition from military to civilian life and approaches to reconnection. PLoS One. 2015;10(7):1-13

[21] Davis VE, Minnis SE. Military veterans' transferrable skills: An HRD practitioner dilemma. Advances in Developing Human Resources. 2017;19(1):6-13

[22] Lutz A. Who joins the military? A look at race, class, and immigration status. Journal of Political and Military Sociology. 2008;36(2):167-188

[23] Barlas FM, Higgins WB, Pflieger JC, Diecker K. 2011 Health Related Behaviors Survey of Active Duty Military Personnel. 2013. Accessed from the Defense Technical Information Center website: https://apps.dtic.mil/ docs/citations/ADA582287

[24] Tice J. Army Expands Involuntary Separations of Problem NCOs.

2014. Retrieved from: http:// www.armytimes.com.dbgw.lis. curtin.edu.au/article/20140501/ CAREERS02/305010057/Armyexpandsinvoluntary-separations-problem-NCOs

[25] Freifeld L. Warriors to workers. Training. 2010;47(5):14-18

[26] U.S. Department of Defense. 2008 Demographics Report. 2008.
Retrieved from: http://download. militaryonesource.mil/12038/MOS/ Reports/2008\%20Demographics.pdf

[27] Reeve R. VA Disability Claims Backlog Down by $84 \%$ Since March 2013. Washington, DC: The Advisory Board Company; 2015

[28] Thompson C. VA Suicide Prevention Program Facts about Veteran Suicide July 2016. Retrieved from: https://www. va.gov/opa/publications/factsheets/ Suicide_Prevention_FactSheet_New_ VA_Stats_070616_1400.pdf

[29] Routon P. The effect of 21st-century military service on civilian labor and educational outcomes. Journal of Labor Research. 2014;35(1):15-38

[30] Savoca E, Rosenheck R. The civilian labor market experiences of Vietnam-era veterans: The influence of psychiatric disorders. The Journal of Mental Health Policy and Economics. 2000;3(4):199-207

[31] Smith MW, Schnurr PP, Rosenheck RA. Employment outcomes and PTSD symptom severity. Mental Health Services Research. 2005;7(2):89-101

[32] Resnick SG, Rosenheck RA. Posttraumatic stress disorder and employment in veterans participating in veterans health administration compensated work therapy. Journal of Rehabilitation Research and Development. 2008;45(3):427-435

[33] Selwyn L. The Civilian Lives of US Veterans: Issues and Identities. Santa Barbara, CA: Praeger; 2017

[34] Smith DL. The relationship between employment and veteran status, disability and gender from 2004-2011 behavioral risk factor surveillance system (BRFSS). Work-A Journal of Prevention Assessment Rehabilitation. 2014;49(2):325-334 
[35] Clemens EV, Milsom AS. Enlisted service members' transition into the civilian world of work: A cognitive information processing approach. Career Development Quarterly. 2008;56(3):246-256

[36] Dickstein B, Vogt D, Handa S, Litz B. Targeting self-stigma in returning military personnel and veterans: A review of intervention strategies. Military Psychology. 2010;22(2):224-236

[37] Harrell MC, Berglass N. Employing America's Veterans: Perspectives from Businesses. Washington, DC: Center for a New American Security; 2014

[38] Bryan CJ, Elder WB, McNaughton-Cassill M, Osman A, Hernandez AM, Allison S. Meaning in life, emotional distress, suicidal ideation, and life functioning in an active duty military sample. The Journal of Positive Psychology. 2013;8(5):444-452

[39] Stone C, Stone DL. Factors affecting hiring decisions about veterans.

Human Resource Management Review. 2015;25(1):68-79

[40] Castro C, Kintzle S, Hassan A. The State of the American Veteran: The Los Angeles County Veterans Study. 2014. Retrieved from USC Social Work Center for Innovation and Research on Veterans \& Military Families website: http://cir. usc.edu/wp-content/uploads/2013/10/ USC010_CIRLAVetReport_FPpgs.pdf

[41] Lowary J. Army Vets have Lofty Expectations; Companies Hesitant to Hire Them. 2017. Retrieved from: https://www.tennessean.com/story/ news/2017/06/08/study-army-vetshave-lofty-expectations-companieshesitant-hire-them/372244001/

[42] Keeling M, Kintzle S, Castro CA. Exploring US veterans' post-service employment experiences. Military Psychology. 2018;30(1):63-69
[43] Brunger H, Serrato J, Ogden J. No man's land: The transition to civilian life. Journal of Aggression, Conflict and Peace Research. 2013;5(2):86-100

[44] Higate PR. Ex-servicemen on the road: Travel and homelessness. The Sociological Review. 2008;48(3):331-347

[45] Rose K, Herd A, Palacio S. Organizational citizenship behavior: An exploration of one aspect of cultural adjustment faced by US Army soldiers transitioning from military to civilian careers. Advances in Developing Human Resources. 2017;19(1):14-24

[46] Baruch Y, Quick C. Understanding second careers: Lessons from a study of U.S. navy admirals. Human Resources Management. 2007;46(4):471-491

[47] Bryant R, Wilhite A. Military experience and training effects on civilian wages. Applied Economics. 1990;22(1):69-81

[48] Morin R. The Difficult Transition from Military to Civilian Life. PEW Research Centre. 2011. Retrieved from: https://www.pewresearch.org/ wp-content/uploads/sites/3/2011/12/ The-Difficult-Transition-from-Militaryto-Civilian-Life.pdf

[49] Biggs D. Military Veterans and LinkedIn: A Qualitative Study Exploring veterans' Challenges Transitioning to the Civilian Workforce and the Potential of LinkedIn as Online Professional Networking Channel. 2014. Retrieved from the University of Minnesota Digital Conservancy: http://hdl.handle. net/11299/192566

[50] Steele JL, Salcedo N, Coley J. Service Members in School: Military veterans' Experiences Using the Post-9/11 GI Bill and Pursuing Postsecondary Education. Santa Monica, CA: Rand Corporation; 2010

[51] Kawaguchi L, Short D. Issues regarding academic credit for veterans 
and military service members: Doing what is best for students. Academic Senate for California Community Colleges (ASCCC). 2012

[52] Frain M, Bishop M, Methel M. A roadmap for rehabilitation counseling to serve military veterans with disabilities. Journal of Rehabilitation. 2010;76(1):13-21

[53] Lindsay S. Discrimination and other barriers to employment for teens and young adults with disabilities. Disability and Rehabilitation. 2011;33(15-16):1340-1350

[54] Cox K, Grand-Clement S, Galai K, Flint R, Hall A. Understanding Resilience as it Affects the Transition from the UK Armed Forces to Civilian Life. United Kingdom: RAND Europe; 2018

[55] Australian Defence Force. Leaving the ADF: Career Transition Assistance Scheme. 2018. Retrieved from: http://www.defence.gov.au/ PayAndConditions/ADF/Chapter-2/ Part-2/

[56] Congressional Research Service. Military Transition Assistance Program (TAP): An Overview. 2018. Retrieved from: https://fas.org/sgp/crs/natsec/ IF10347.pdf

[57] MacLean MB, Van Til L, Thompson JM, Sweet J, Poirier A, Sudom K, et al. Postmilitary adjustment to civilian life: Potential risks and protective factors. Physical Therapy. 2014;94(8):1186-1195

[58] The Economist. Veterans Day: Difficult Transitions. 2014. Retrieved from: https://www.economist.com/ democracy-in-america/2014/11/12/ difficult-transitions

[59] Prudential Financial Inc. Veterans' Employment Challenges: Perceptions and Experiences of Transitioning from
Military to Civilian Life. 2012. Retrieved from: https://www.voced.edu.au/ content/ngv\%3A60692

[60] Bergman M, Herd A. Proven leadership = college credit: Enhancing employability of transitioning military members through prior learning assessment. Advances in Developing Human Resources. 2017;19(1):78-87

[61] Berrett D. Words from Wartime. Inside Higher Ed. 2011. Retrieved from: http://www.insidehighered.com/

[62] O’Herrin E. Enhancing veteran success in higher education. Peer Review. 2011;13:15-18

[63] Collins B, Dilger RJ, Dortch C, Kapp L, Lowry S, Perl L. Employment for Veterans: Trends and Programs. ILR School. Federal Publications: Cornell University; 2014

[64] United States Department of Labor. Vets fact sheet 1 - Transition Assistance Program. 2018. Retrieved from: http:// www.dol.gov/vets/programs/tap/ tap_fs.htm. [Accessed: 26 October 2018] 



\section{Edited by Josiane Fahed-Sreih}

This book, "Career Development and Job Satisfaction", not only looks at how employees can develop their careers and create career paths that are meaningful for their lives, it also looks at keeping employees satisfied with their jobs.This book highlights how to work with the millennial generation and being able to motivate them and guide them through their careers. It presents case studies on satisfaction and career planning. The function of human resource management has an important implication on the performance of the whole organization and giving it acute attention can enhance the performance of the business. 